\title{
اتتصاديات المشروعات الصغيرة وسبل النهوض بها فى ضوء التجربتين الماليزية والهندية
}

\author{
shel \\ د / حازم السيد حلمى عطوة مجاهد \\ أستاذ الاقتصاد والماليتّا العامت المساعد \\ الجامعت العماليت - فرع المنصورة
}




\section{هقدهة}

تشكل المشروعات الصغيرة العصب الـرئيس لاقتصاد أي دولـة سـواء أكانـت

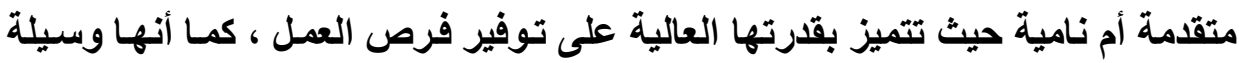

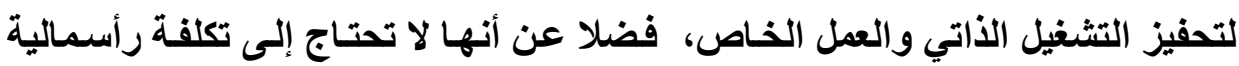
عالية لبدء النشاط فيها، كذلك تتميز هذه المشروعات بقدرتها على توظيف العمالة نصف الماهرة وغير الماهرة، كما أنها تعطى فرصة للتدريب أثناع العمل لرفع القدرات لهدهات

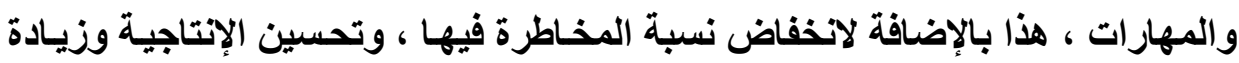

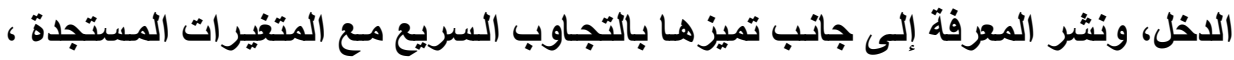

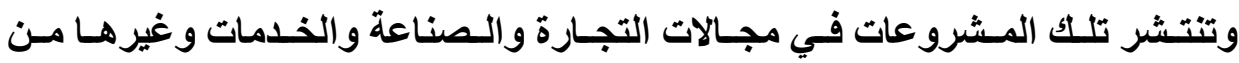
القطاعـات الاقتصادية ، وتتجـه بعض اللدول لتنميـة المشروعات الصغيرة مـن خـلال

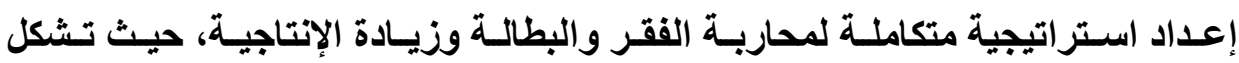
المشروعات الصغيرة مجالا حيويـا لروح المبادرة واستغلال الموارد الأولية المحلية

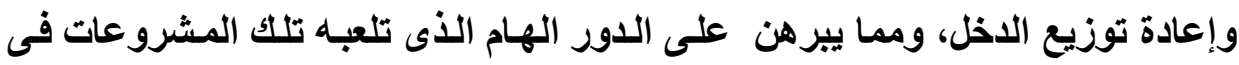

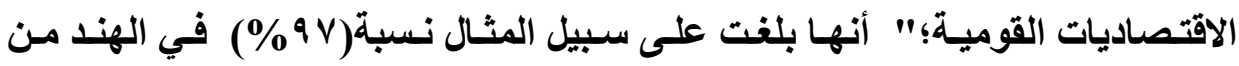

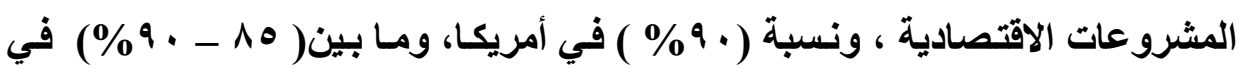

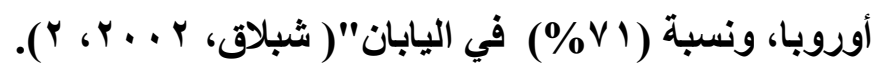

وعلى الرغم من أهمية المشروعات الصغيرة واهتمـام الدول المتقدمة بها، إلا

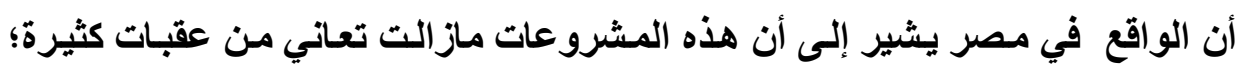

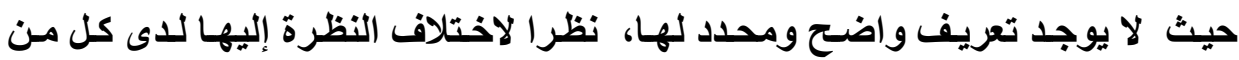

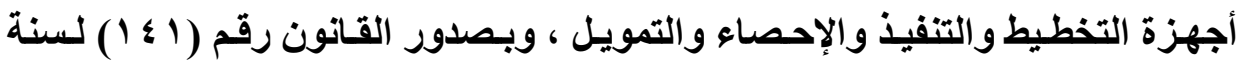

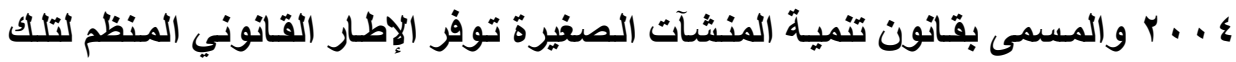

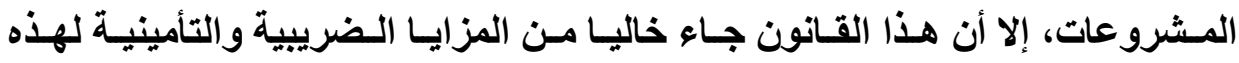

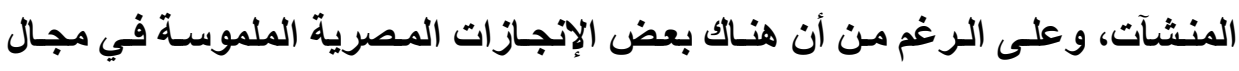




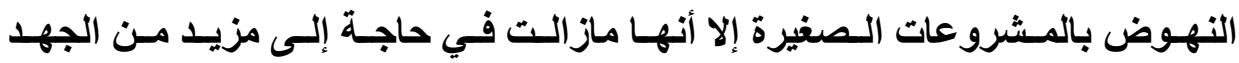

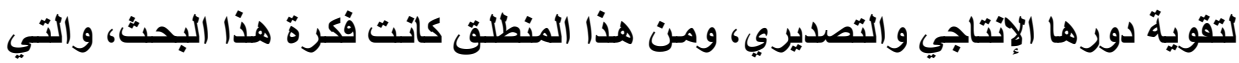

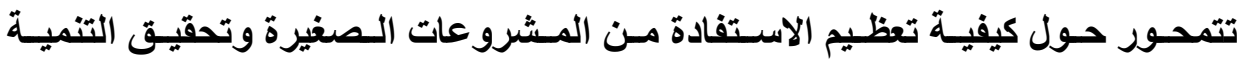
الاقتصادية المرجوة، وسوف يزداد الأمر وضوحا بعد تحديد مشكلة البحث في السطور الاسئ

\section{مشكلة البحث}

تم تحديد مشكلة البحث في الأسئلة الآتية: ا - ما المقصود بالمشروعات الصغيرة، وما أهم السمات التي تكسبها ميزة تنافسية

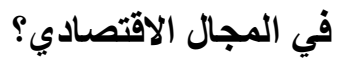

r - كيف شُسهم المشروعات الصغيرة في إحداث التنمية الاقتصادية؟

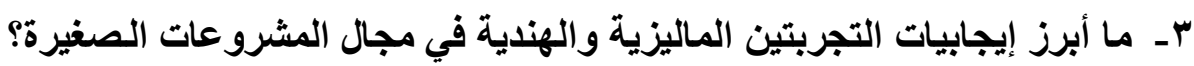

$$
\text { وما الاروس المستفادة منها؟ }
$$

ـ ـ مـا الواقع الحسالي للمشروعات الصغيرة في مـصر؟ ومـا أهم التحديات التـي

$$
\text { تواجهها }
$$

هـ مـا سبل النهوض بالمشروعات الصغيرة في ضوه تحديات الواقع المصري

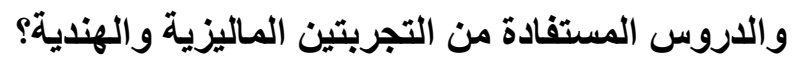

\section{أهد|ف البمث}

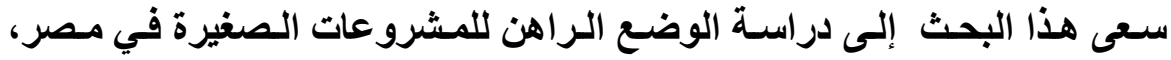

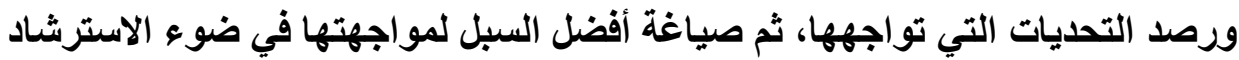

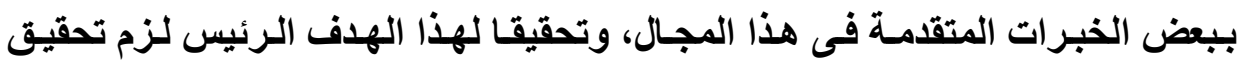

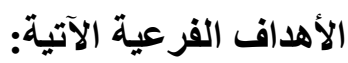

1- إلقاء الضوء على مفهوم المشروعات الصغيرة، وأهم الخصائص المميزة لها والتي تُضفي عليها ميزة تنافسية في المجال الاقتصادي.

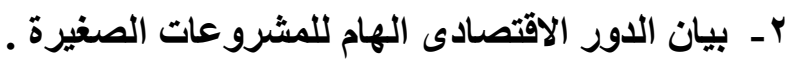




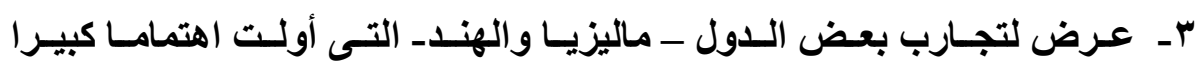

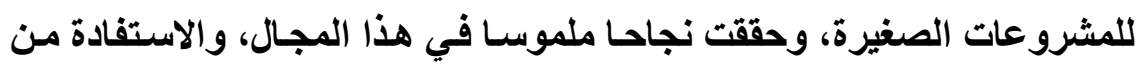
ذلك في كيفية النهوض بالمشروعات الصغيرة في مصر.

\section{أهمية البحث}

ترجع أهمية البحث لأمور منها:

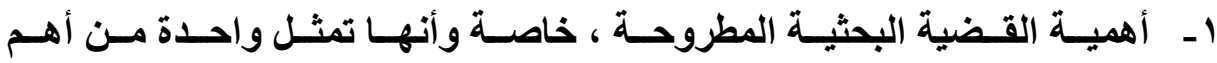

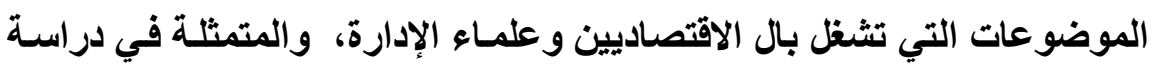
المشروعات الصغيرة وأثرها على التنمية الاقتصادية.

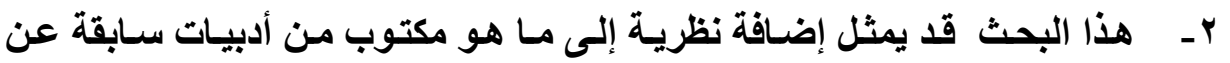
موضوع المشروعات الصغيرة ودورها في تحقيق التنمية الاقتصادية.

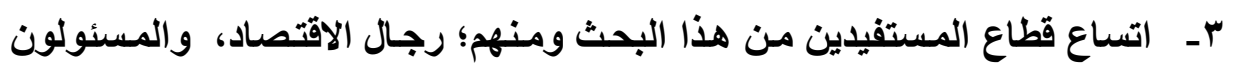

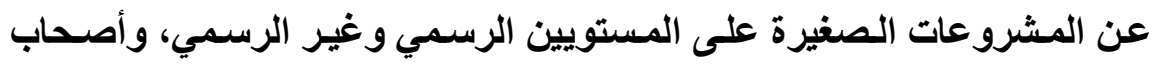

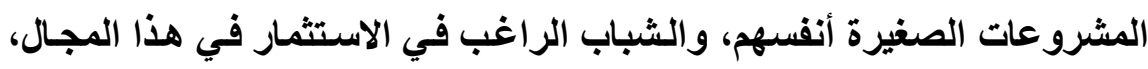

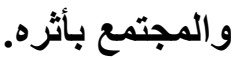
ع ـ ق يمثل هذا البحث ناقذة للوقوف على تجارب وخبرات بعض الدول المتقدمة في

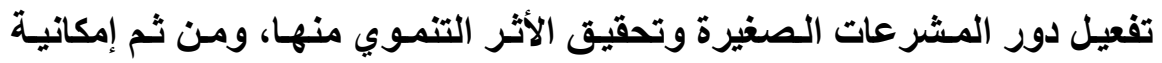
النهوض بالاقتصاد المصري. هنهمج البمث

اعتمـد البحث علـي المنهج الوصفي ، نظرا لملاعمته لطبيعة القضية البحثية

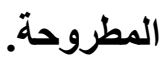
هطة البمث تمت معالجة هذه القضية البحثية في خمسة مباحث على النحو الآتي المبحث الأول : الإطار المفهومي للمشروعات الصغيرة. 
المبحث الثانى : الدور الاقتصادى للمشروعات الصغيرة.

المبحث الثالث : التجربة الماليزية والهندية للنهوض بالمشروعات الصغيرة

$$
\text { و الاروس المستفادة منها . }
$$

المبحث الرابع : المشروعات الصغيرة فى مصر (الواقع- التحديات).

المبحث الخامس: سُبل النهوض بالمشروعات الصغيرة.

ويسبق هذه المحاور الخمسة ؛ الإطار العام للبحث ـ متضمنا الإحساس بالمشكلة

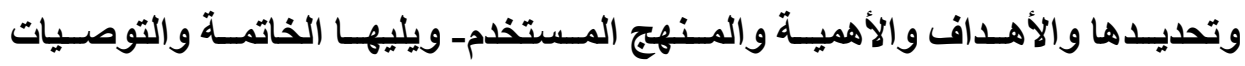

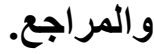




\section{المبحث الأول \\ الإطار المفهوهي للمشروعات الصغيرة}

\section{ماهية المشروعات الصغيرة}

تواجـه معظم الـدول صسوبة في تحديــ تعريـف محسد وموحـد للمششروعات

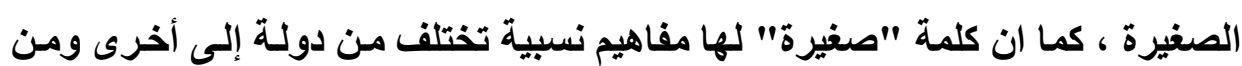

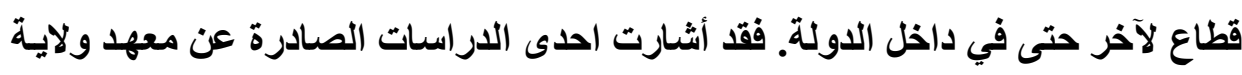
جورجيا بأن هناك أكثر من (00) تعريفاً للمشروعات الصغيرة في (V0) دولة، ويتم تعريف المشروعات الصغيرة اعتماداً على مجموعة من المعايير منها عدد العمال، حجم رأس المال، أوخليط من المعيارين معاً، وهناك تعريفات أخرى تقوم على استخدام حجم

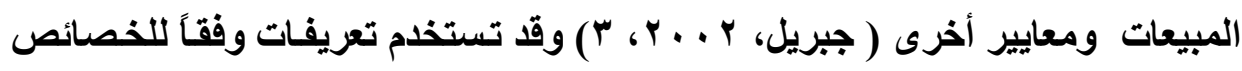
الوظيفية مثل نوع الإدارة أو التخصص أو أساليب الإنتاج أو اتجاهـات السوق، ومئل ويعتبر

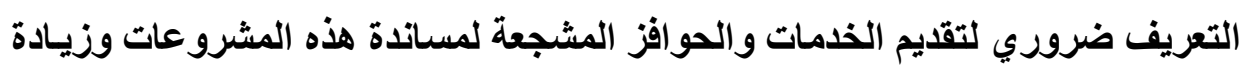

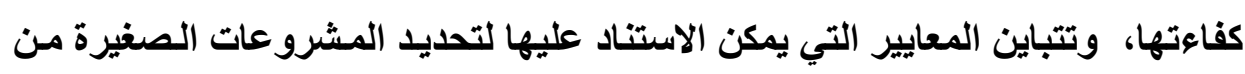
دولة لأخرى وفق إمكاناتها وقراتها وظروفها الاقتصادية ومراحل النمو التي بلغتها. فالبنك الدولي على سبيل المثال يعرف المشروعات الصغيرة باستخدام معيار

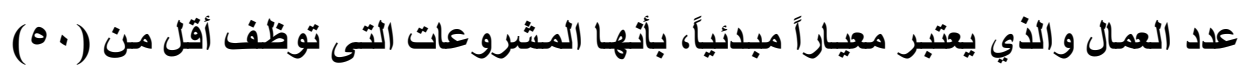

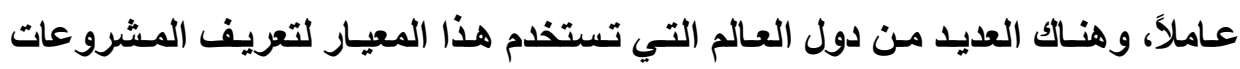

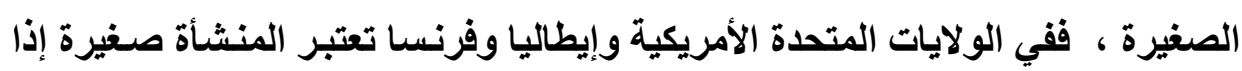

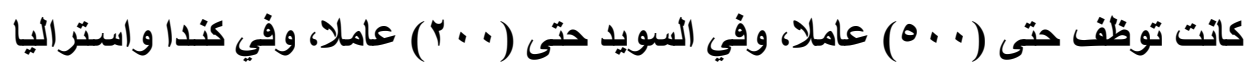

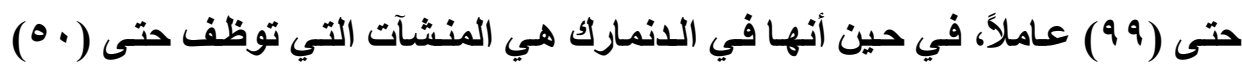

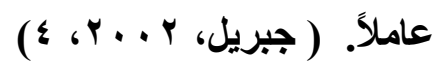


وتعرف منظمة الأمم المتحدة للتمية الصناعية (اليونيدو) المشروعات الصغيرة

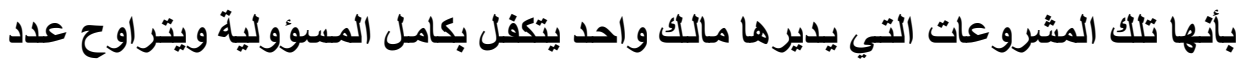

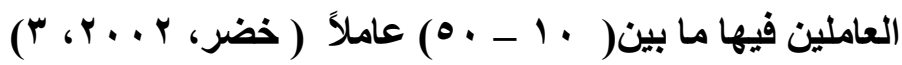
كما تتعدد تعريفـات المشروعات الصغيرة التي تتسب إلى جهات مختلفة على النحو الآتي: • عرفت وكالة التنمية الدولية الدانمركية (دنيدا) المشروعات الصغيرة : أنها تلك

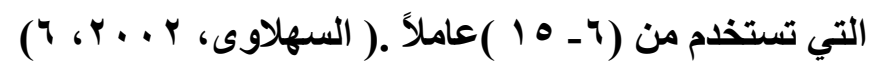
• في حين ذهب بنك التنمية الصناعية في مصر إلى تعريف المشروعات الصغيرة :

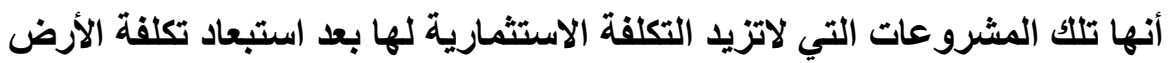

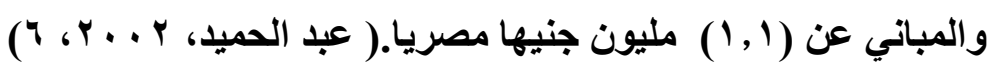

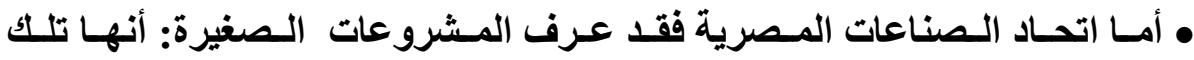

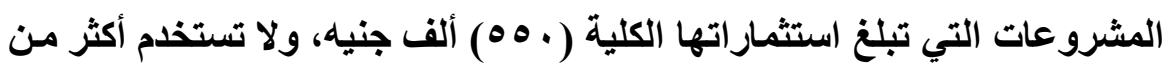

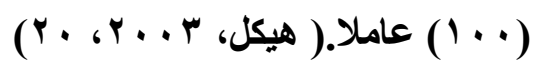

• أما منظمة العمل الدولية فقد عرفت المشروعات الصغيرة: أنها وحدات صغيرة الحجم تتتج وتوزع سلعاً وخدمات، وتتألف من منتجين مستقلين يعملون لحسابهم

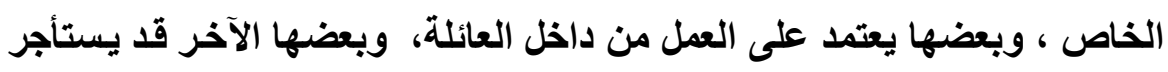

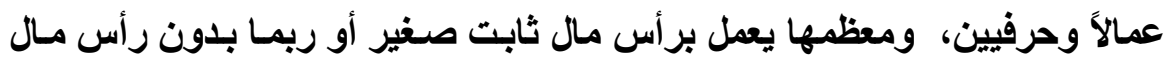

$$
\text { ثابت. (Aygagari, 2003,2-3 ) }
$$

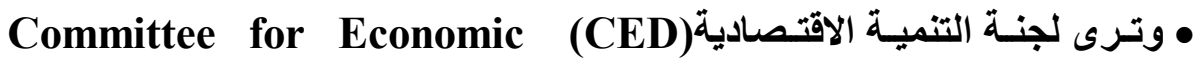
هevelopment

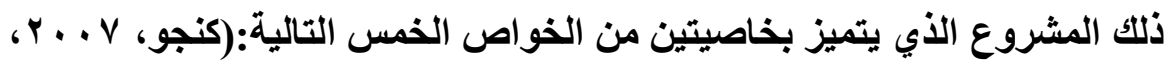

1 - يديره أصحابه بثكل أساسي وبصورة مستقلة. r - بحمل الطابع الشخصي إلى حد كبير. 
r- ـ يكون محلياً إلى حد كبير في المنطقة التي يعمل بها.

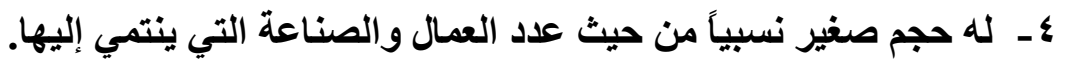

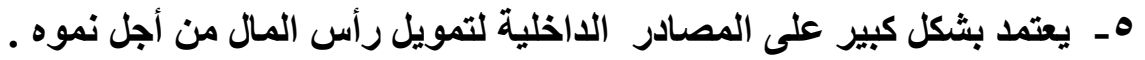

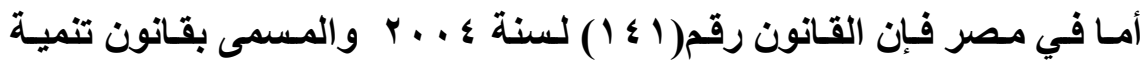
المنشآت الصغيرة، فقد عرفها؛ بأنها كل شركة أو منشأة فردية تمارس نشاطا اقتصاديا

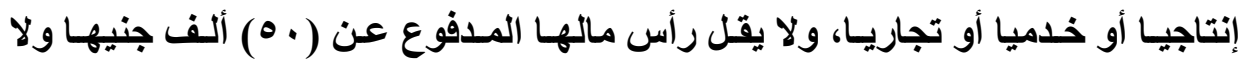

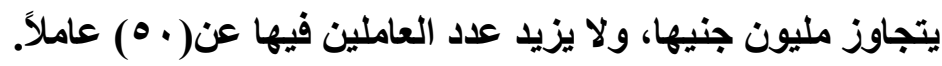
مما تقدم يمكن القول أنها من الصعب تحديد مفهوم دقيق وشـامل للمشروعات

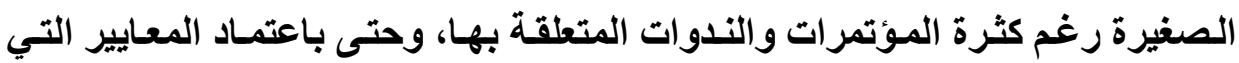

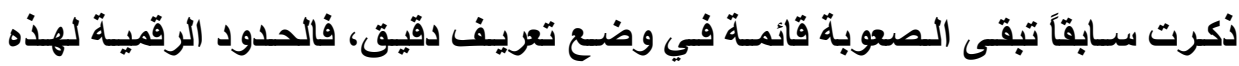
المعايير لم يتم الاتفاق عليها بسبب اختلاف الخصائص والقدرات والظروف الاقتصادية والاجتماعية بين بلا وآخر.

لذا فإنه قد يكون من الأفضل عدم التقبد بمعيار محدد للمشروعات الصغيرة وإنما وضع مجموعة من المعايير والمؤشرات التي تختار لتتناسب مع طبيعة اقتصاد كل دولة التئ وعلى أساسها يتم تصنيف المشروعات الى صـغيرة أو متوسطة أو كبيرة ومن ثم يتم

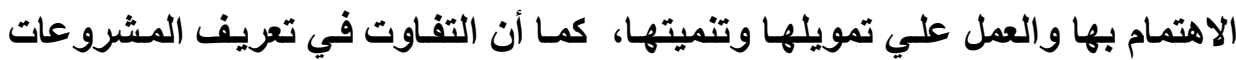

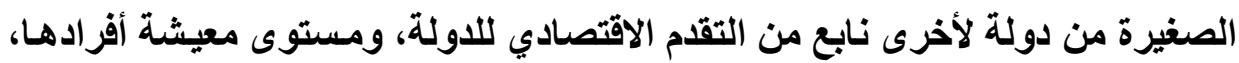
ومدى التقدم في استخدام التكنولوجيا.

\section{خصائص وهميزات المشروعات الصغيرة}

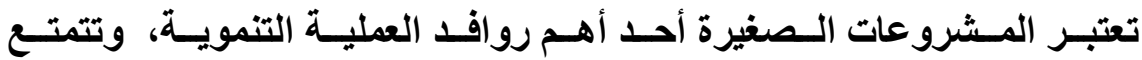
المشروعات الصغيرة، بخصائص معينة تميزها عن غيرها ، ومن هذه الخصائص الآتى

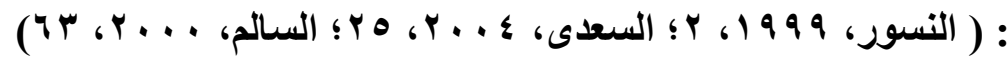
1- سـهولة تكوين هذه المشروعات: لانخفـاض الاحتياجـات الماليـة (رأس المـال

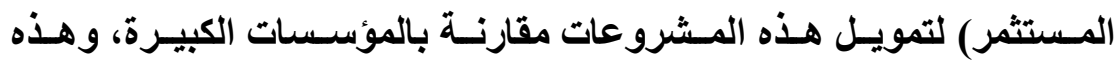




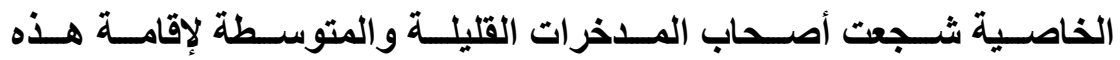
المشروعات، ويمكن أن تكون على شكل مؤسسة أفراد أو شركات تضامن،

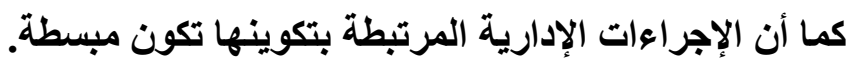

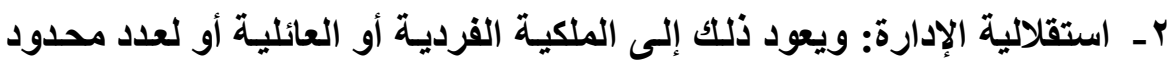
من الأفراد لهذه المشروعات وعليه فإن معظم هذه المشروعات يكون مديرها

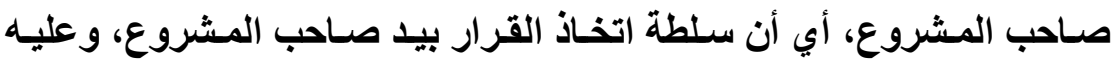
يمكن لصاحب المشروع استقطاب وإرضاء العديد من الأيدي العاملة والعملاء.

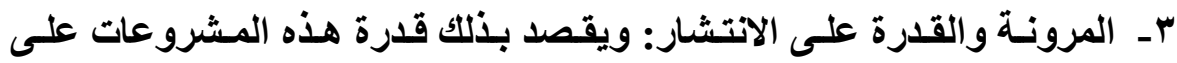

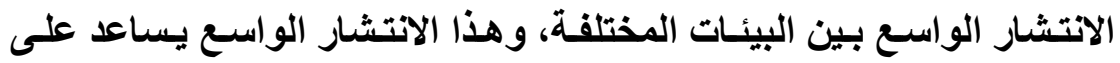

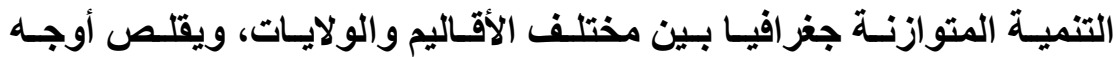
التفاوت في توزيع الدخل والثروة بين المنـاطق، ويساهم في إعادة التوازن

$$
\text { السكاني للاولة. }
$$

عـ تـوفير فرص عمل جديـدة: إن المشروعات الصغيرة قـادرة على امتصاص البطالة وإيجاد فرص عمل جديدة لأنها لا تتطلب المهارات القنية التي تتطلبها

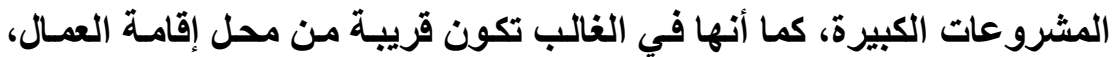
مما يوفر مصروفات السكن والسفر وغير ذلك.

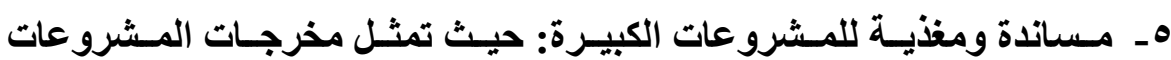
الصغيرة مدخلا للمشروعات الكبيرة لارجة أنها أصبحت لا تستطيع الاستغناء

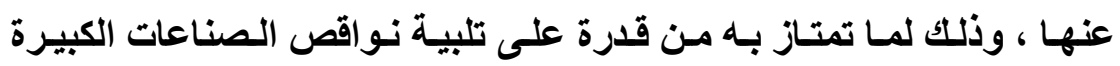

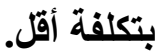
צ- ترقية روح المبادرة الفردية والجماعية: نظرا لحرص العاملين في المشروع

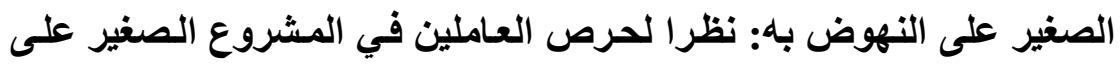
النهوض به ورغبتهم في استحداث أنشطة اقتصادية سلعية أو خدمية لم تكن موجودة من قبل، و كذا إحياء أنشطة اقتصادية تم التخلي عنها كالصناعات التقلبدية. 
V- الفعالية في التسيير: تتبع المشروعات الصغيرة في الغالب طرقا للتسيير لا

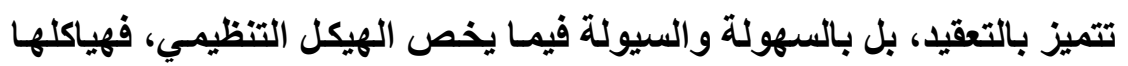

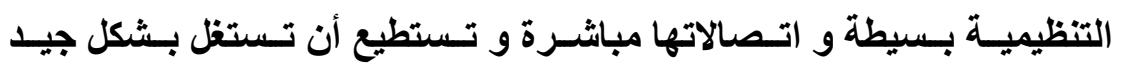

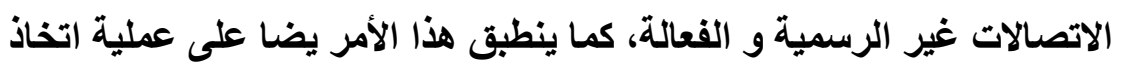

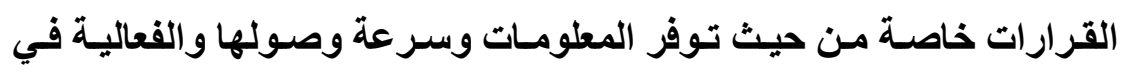
استخدامها، وهذا لا يمنع من استخدام أساليب التسيير الحديثة.

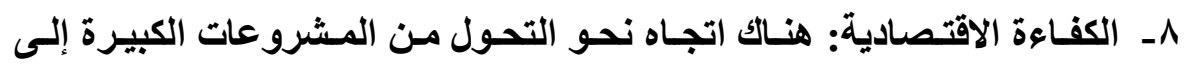

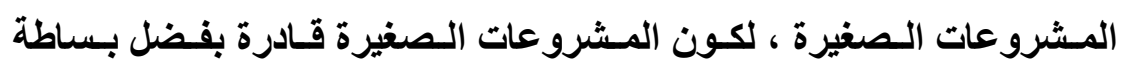
التكـوين وجـودة الإدارة على تقـديم الخــمات المتميـزة وتوصسيل منتجاتهـا للمستهلكين بشكل أفضل من منافسيها الكبار.

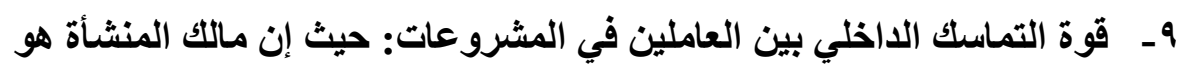
مديرها في أغلب الأحيان ، ومن ثم فهو يسعى باستمرار لكسب تأييد وتعاون العاملين معه وحثهم على الاجتهاد والحرص على مستقبل الاجبل المنشأة.

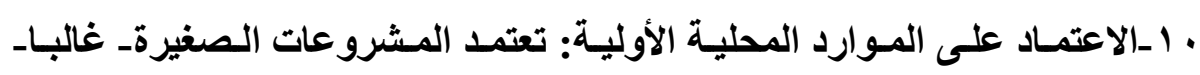

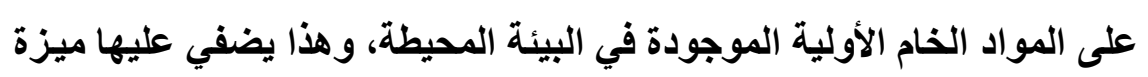

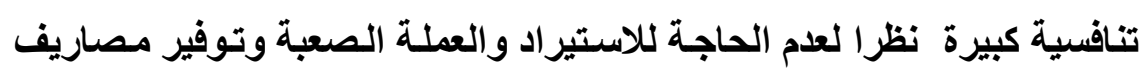

$$
\text { النقل وغير ذلك من المزايا. }
$$

1 أـلب هذه المشروعات يتسم بالروح الأسرية : ويرجع ذلك إلى قلة عدد العمـال

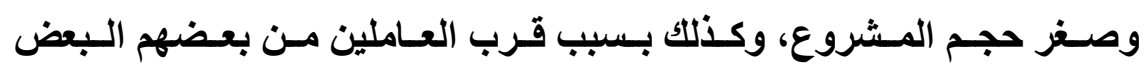

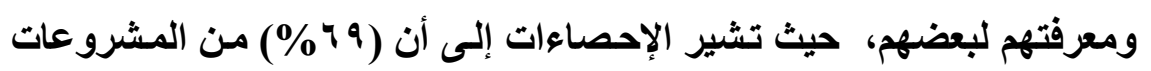

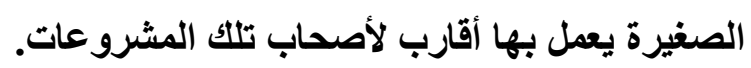

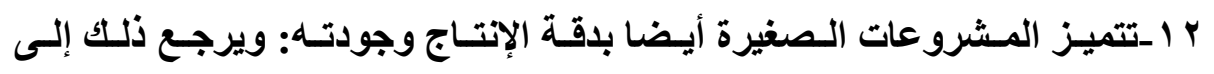

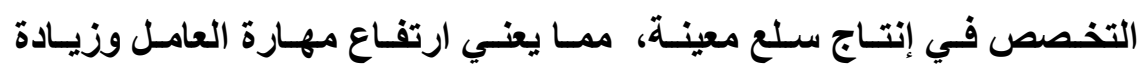

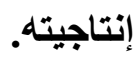




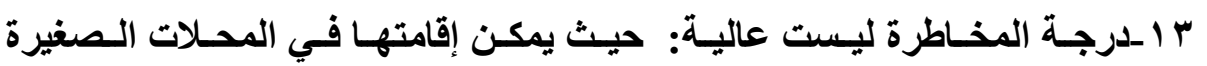

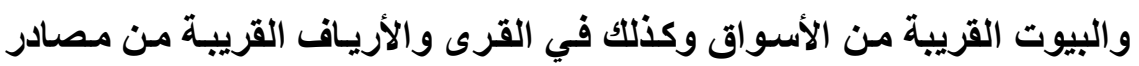

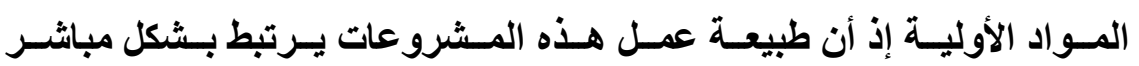

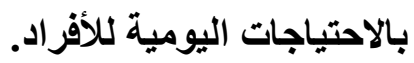

وبعد عرض السمات والخصائص التى تتميز بها المشروعات الصغيرة ، قد

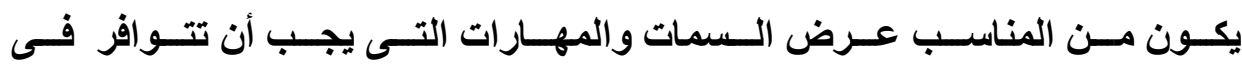
الثخص صاحب المشروع الصغير حنى يكتب له النجاح فى إدارة هذا المشروع بدرجة

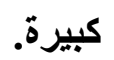

\section{السهات والمهارات الشخصية المطلوبة لأصحاب المشروعات الصغيرة}

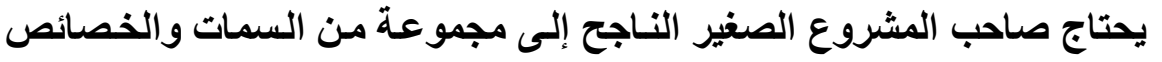

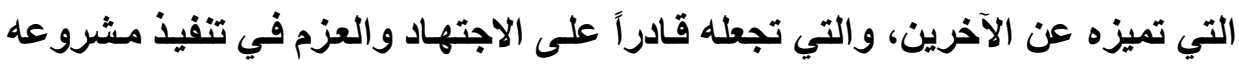

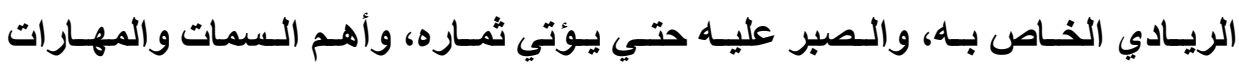

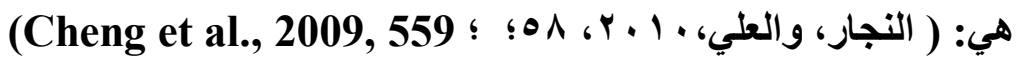

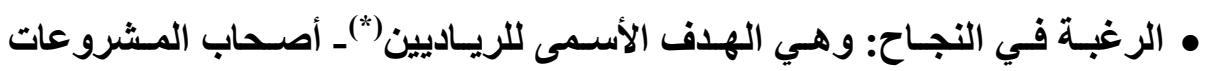

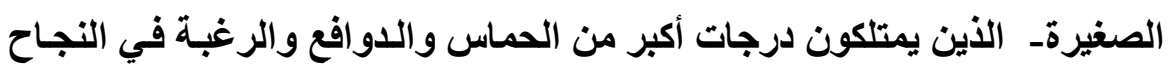

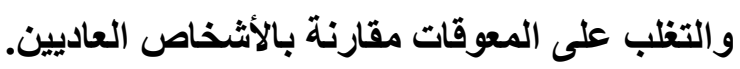
• الثقة بالنفس: تساعد الثقة بالنفس الريادي على النجاح في عمله من خلال القدرة

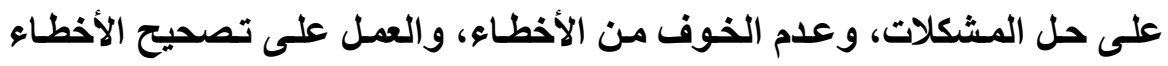

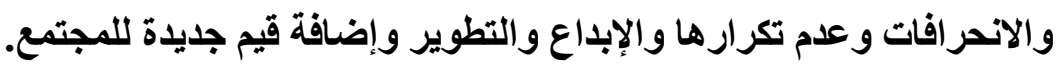

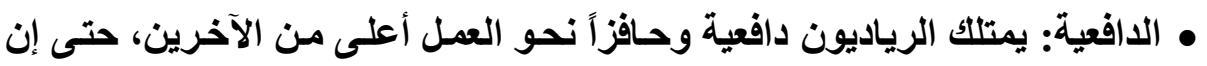

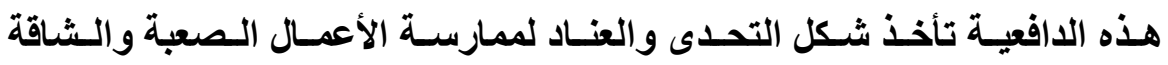


و المرهقة دون كلل أو ملل، كمـا أن لايهم استعداد للعمل لساعات طويلـة، وفي

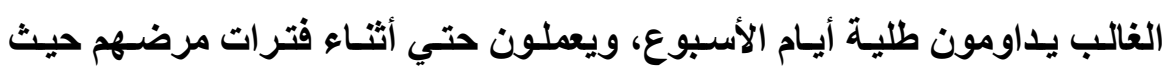
يرون أن العمل يساعد على سرعة شفائهم.

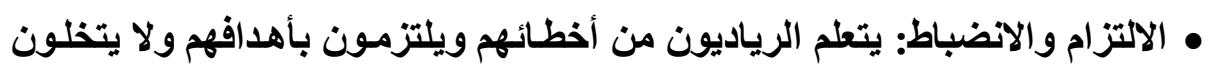

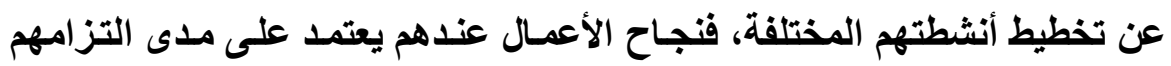
ومثثابرتهم في العمل.

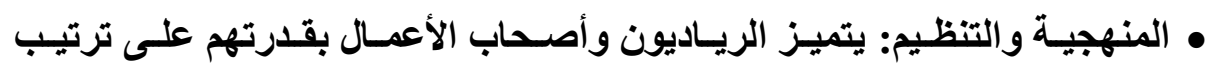

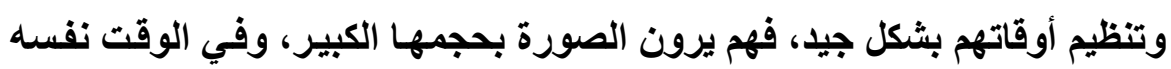

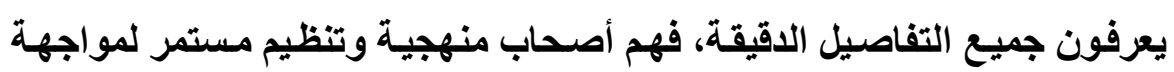

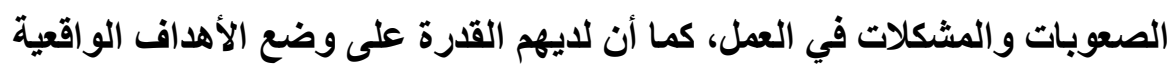
القابلة للإنجاز ، والالتزام طويل الأجل بتنفيذها.

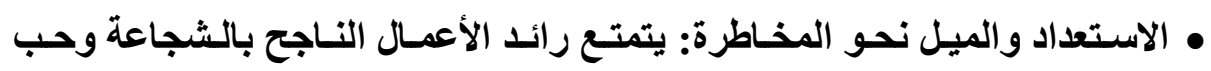

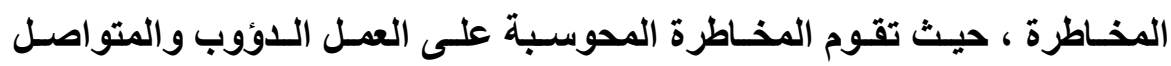

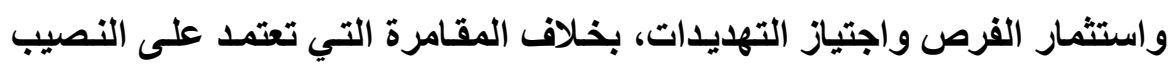

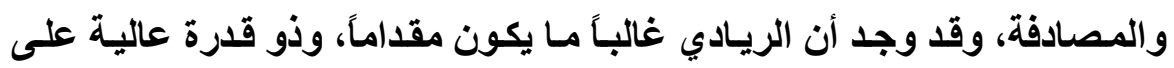

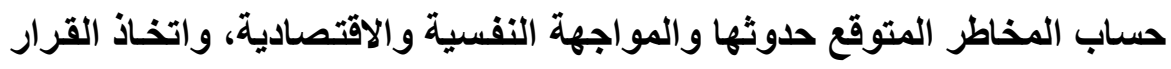
المناسب للتفلب على تلك المخاطر

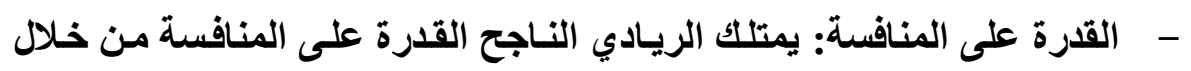

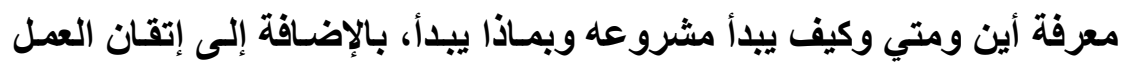

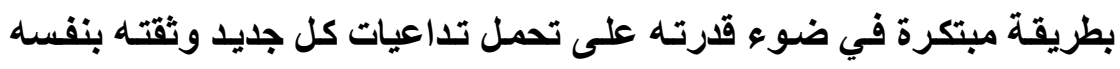

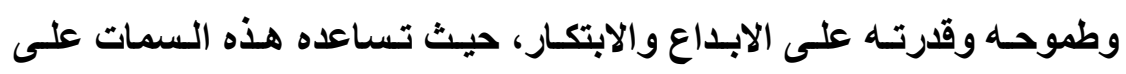

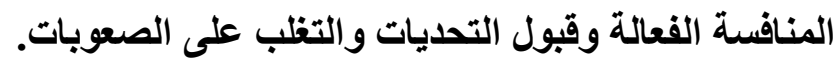

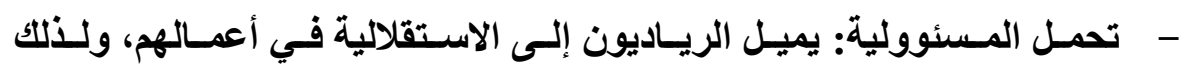
ينجزون ويديرون أعمالهم بطريقة متميزه وبروح المسؤولية العالية، وتأتي 
المسؤولية مـن الروح القياديـة التـي يتمتعون بهـا وبقدرتهم على مواجهة

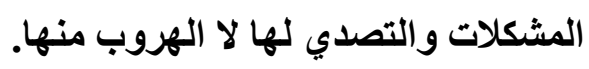

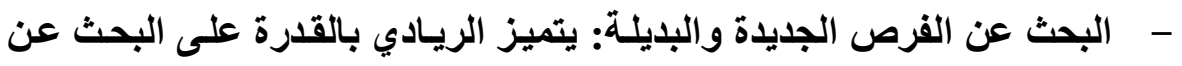

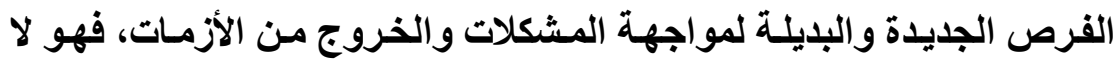

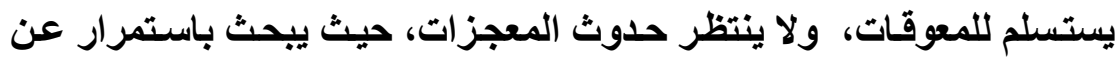
الفرص الجديدة لتحسين العمل أو تسويق منتجاته أو تطوير ها بطريقة مبتكرة، ويعتمد على مصادر متعددة للحصول على أفكار جايدة.

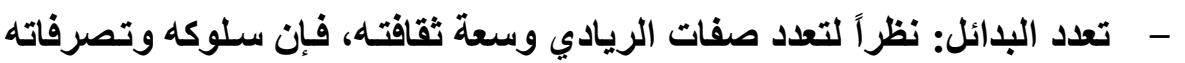

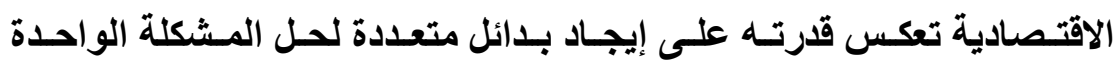
و الوصسول لهافه مـن أقصر طريق، حيث يتقن استخذام البدائل واستحداث المصادر المعرفية والتمويلية.

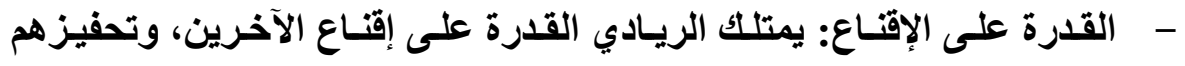

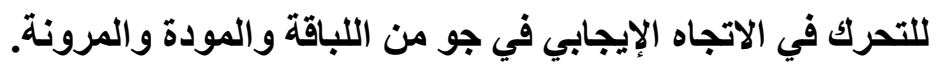

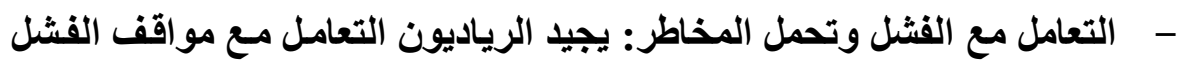

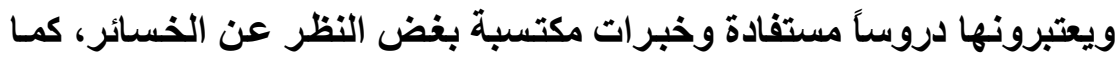

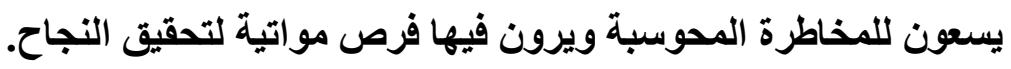

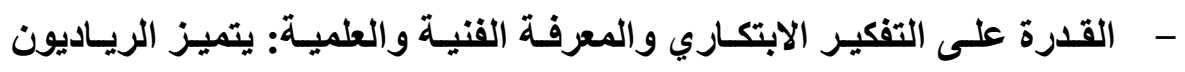

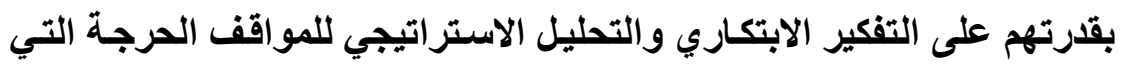

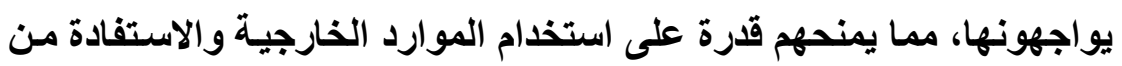

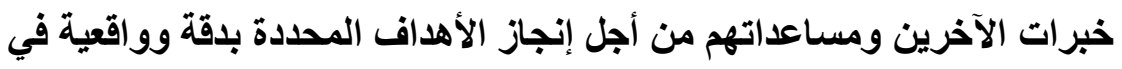

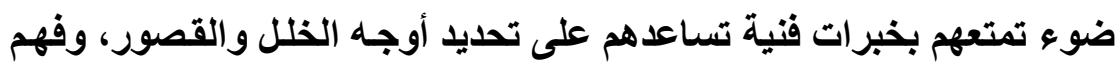

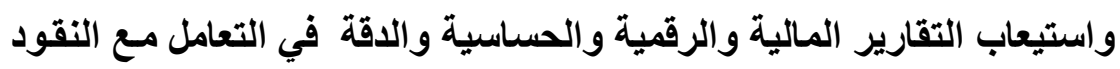
لوضع كل مبلغ مالي في محله . 
وبالإضافة إلى السمات السابق ذكرها وضرورة توافرها فى صـاحب المشروع لكى ينجح هذا المشروع ، هنـاك أيضا عناصر لابـد من وجودهـا لإتمـام هذا النجـاح توضحها السطور التالية:

\section{عناصر تشغيل المشروع الصغير}

يحتاج المشروع الصغير إلى مجموعة من العناصر الأساسية لتشغيله ، و هذه

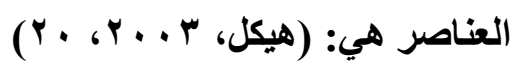

- الإدارة ( Management ) وتثضمن جميع الوظائف والأنشطة التي تقوم بها

$$
\text { إدارة المشروع لضمان تشغيله بصورة جيدة. }
$$

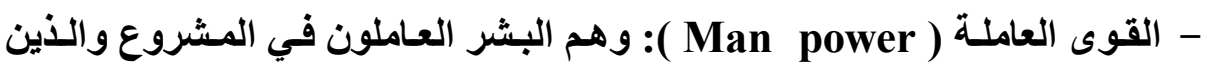
يعملون على إنتاج السلع وتقديم الخدمات سواء أكانوا فنيين أم إداريين. - المواد ( Materials ) : وهي الخامات التي تدخل في إنتاج السلع والخدمات التي

$$
\text { يقدمها المشروع لزبائنه. }
$$

- الآلات والمعدات ( Machines ) : وهي ما يحتاجه المشروع من ماكينـات وآلات

$$
\text { لإنتاج السلع وتقديم الخدمات. }
$$

- السوق ( Market ) - لإبع وهم الزبائن الحاليين والمحتملين. - المال ( Money ) ) وهو أساسي لتحقيق وإنجاز المتطلبات السابقة. وبالإضـافة لمـا سـبق فإنـه يجب أن يكون واضـحا أن العناصر الماديـة والماليـة

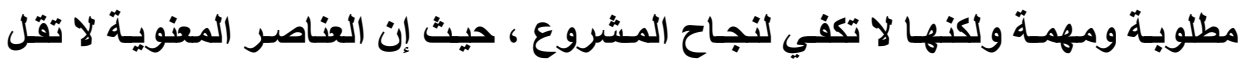
أهمية عن العناصر الماديـة وهي الفكرة المناسبة والإصرار والتحدى والثقة بـالنفس وله والعلاقات الإنسانية وغيرها.

عرض هذا المبحث لمفهوم المشروعات الصغيرة والسمات والخصائص التى هو هات

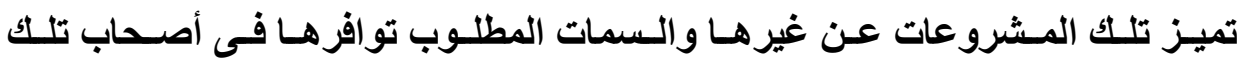

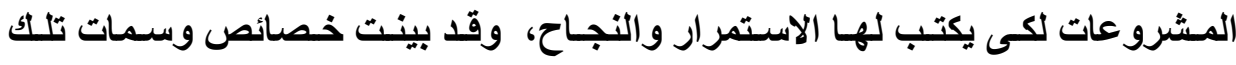


المشروعات مدى أهميتها للاول النامية ومن بينها مصر، و وأنها الأنسب لعملية التنمية

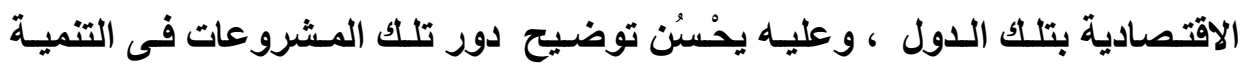
الاقتصادية ومدى أهيتها وذلك من خلال المبحث القادم. 


\section{المبحث الثاني \\ الدور الاقتصادى للامشروعات الصغيرة}

تحتل المشروعات الصغيرة الأهميـة الأولى في الاقتصاديات الوطنيـة كونهـا

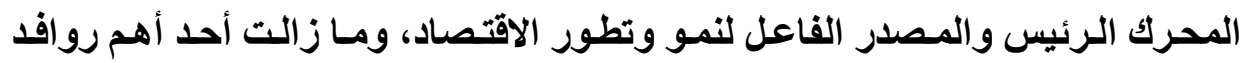

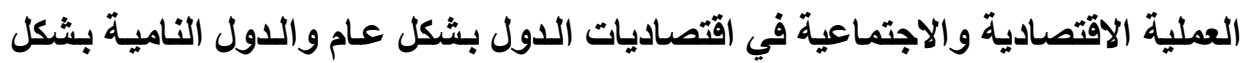
خاص، كمـا تعد العمـود الفقري لأي اقتصاد وطنـي، وخاصـة بعد أن شـهـ هذا القطاع انتشاراً واسعاً في مختلف أرجاء العالم خلال السنوات الأخيرة وأصبحت تشكل نسبة واهية

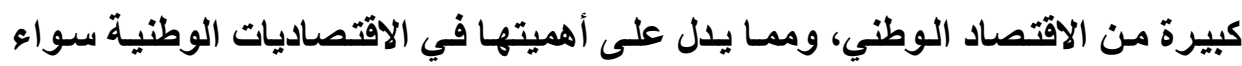

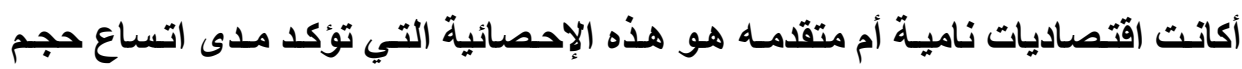

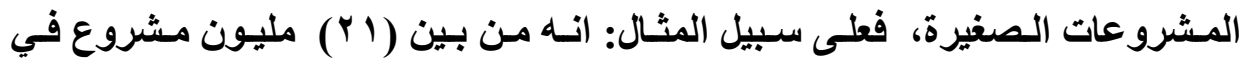

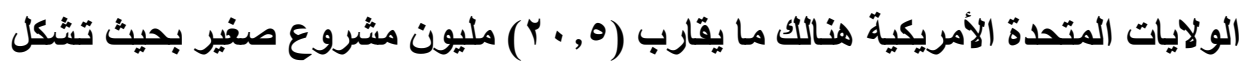

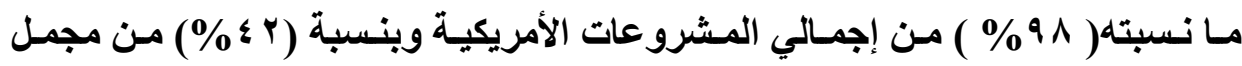

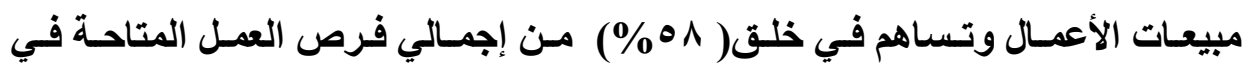

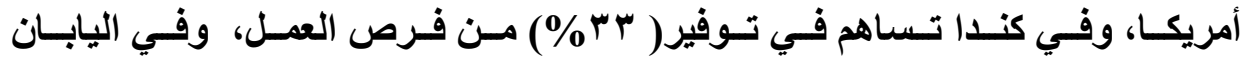

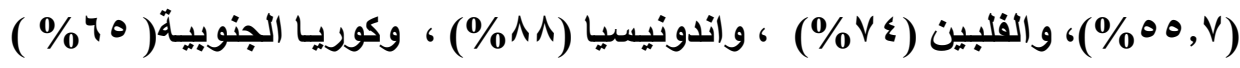

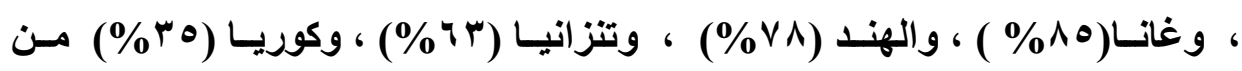

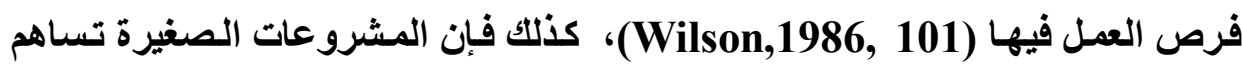

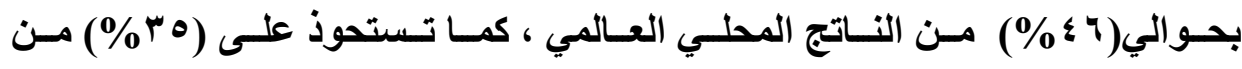

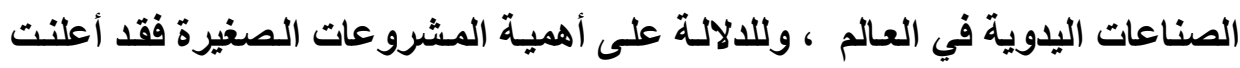

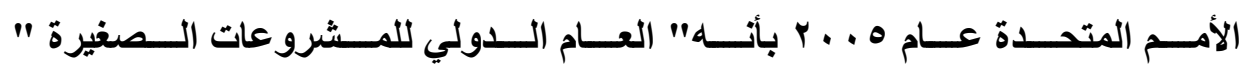

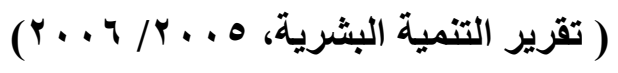


ويحتـل قطــاع المـشروعات الـصغيرة مكانـة متميـزة ضــمن أولويـات التتميـة الاقتصادية والاجتماعية في الدول العربية ، ويتوقع لهذه المشروعات أن تكون قاطرة

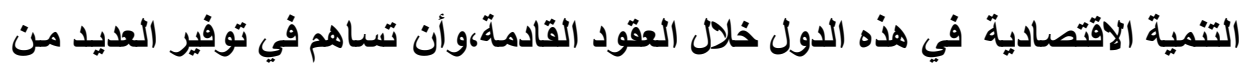

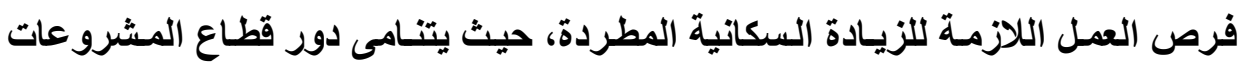
الصغيرة في خلق الوظائف لمقابلة احتياجات الدول العربية باستحداث ( . . 1) مليون فرصة عمل فيها خلال العثرين سنة القادمة، ومكافحة البطالـة في الدول العربية التي

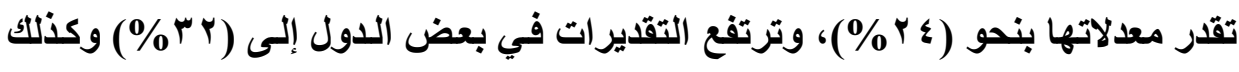

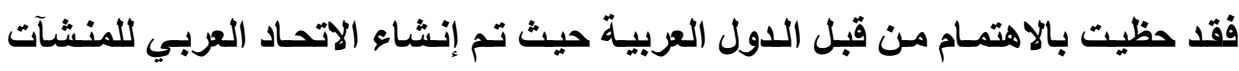

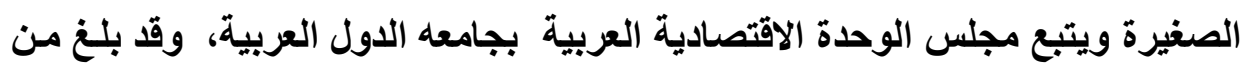

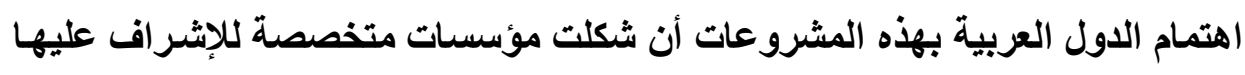

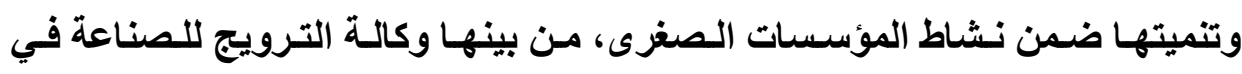

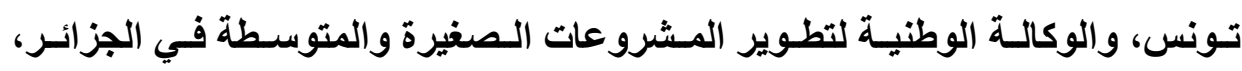

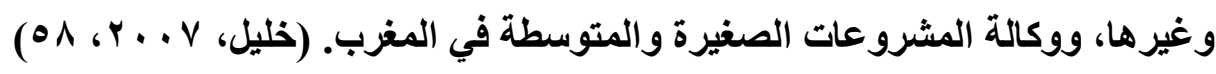

ولقد تغيرت النظرة إلى هذا النوع من المشروعات، حيث أكدت معظم البحوث

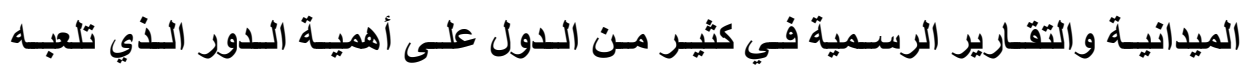

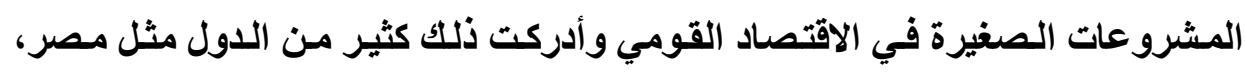

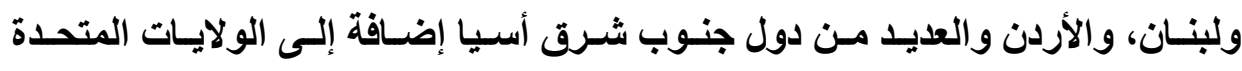

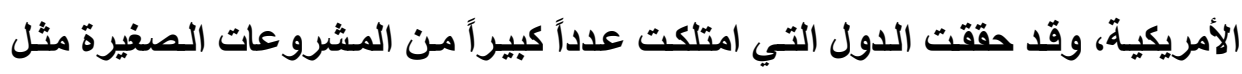
ايطاليا وتايوان وهونج كونج نموا اقتصاديا أسرع من جار اتها التي امتلكت شركات

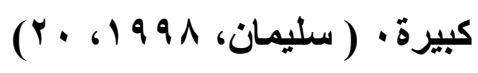

ويمكن الإشـارة إلى أهميـة هذه الصناعات بمـا ذكره فريدمان (Friedman) ، وهات

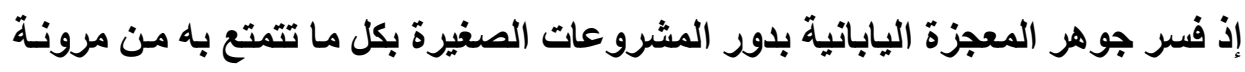

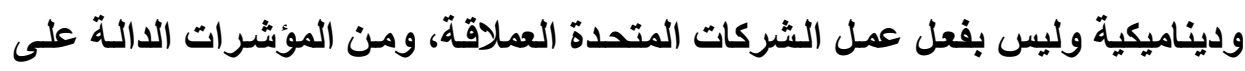

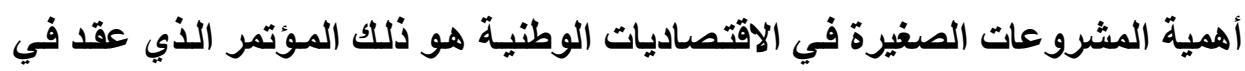


البيت الأبيض عام • 19 1 لتحديد ماهية المشروعات الصغيرة، حيث شـارك فية العديد

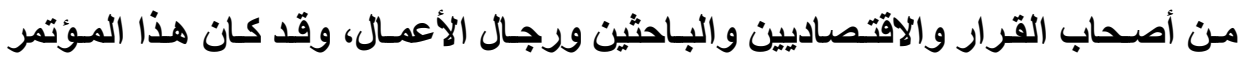

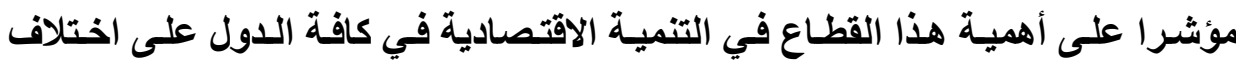

أنظمتها الاقتصادية . (Thorsten\& Aygagari,2003, 2-3 )

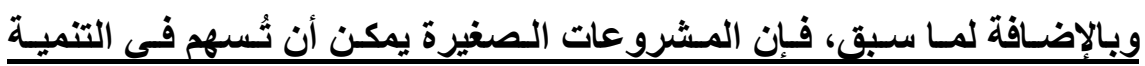

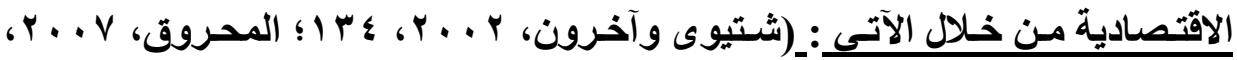

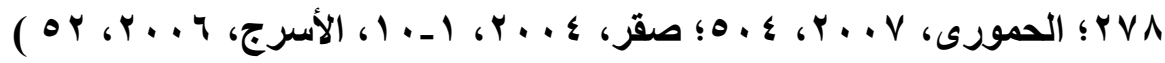

1- الحــ مـن مشكلة البطالـة : حيث تستخدم المشروعات الصغيرة فنونـاً إنتاجية

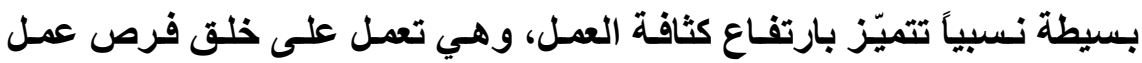

تمتص جزعاً من البطالة وتعمل في ذات الوقت على الحد من الطلب المتزايد على الوظائف الحكومية؛ مما يساعد الدول التي تعانى من وفرة العمالة وندرة

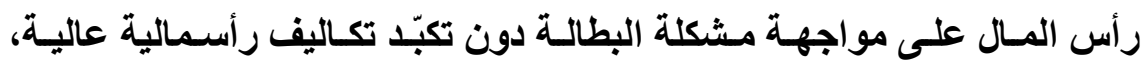
وتوفر هذه المشروعات فرصاً عديدة للعمل لبعض الفئات، وبصفة خاصة الإنـاث

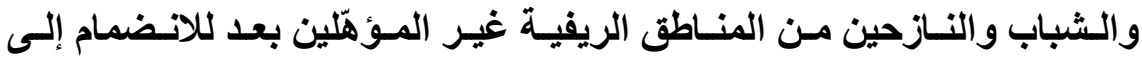
المشروعات الكبيرة والقطاع المُنظم بصفة عامة.

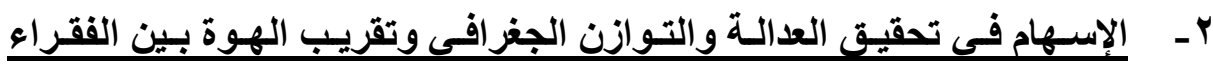
والأغنياءٍ: ففي العديد من التجارب التنموية نمت المراكز الحضرية على حساب

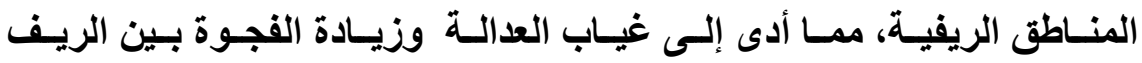
والحضر، ولهذا فإن التوسع في المشروعات الصغيرة وانتشارها يساعد على في إنى تخفيف غياب التوازن في توزيع الاخول، إضافة إلى تقليل تمركز المشروعات الميرة

$$
\text { في المدن وزحف أهل الريف إلى المدن. }
$$
r- تحقيق التزابط بينها وبين القطاعات الاقتصادية الأخرى: مثل الزراعة وقطاع

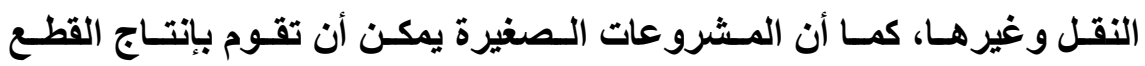

$$
\text { والأجزاء التي تحتاجها المشروعات الكبيرة. }
$$


ع - الإسهام في ضبط الموازنة العامة وميزان المدفوعات : حيث تلعب المشروعات

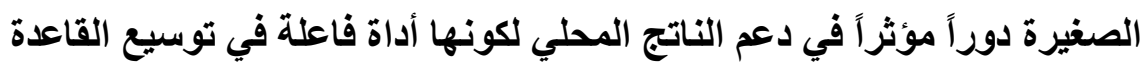

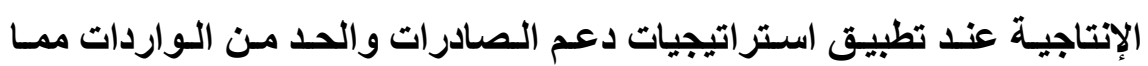

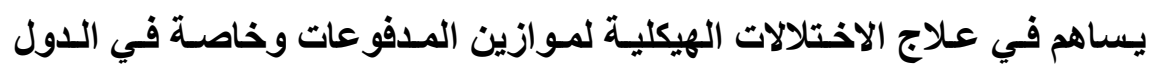
النامية. هـ تغذية الصناعات الكبيرة بمستلزمات الإنتاج: حيث تعتمد الثركات الدولية حالياً

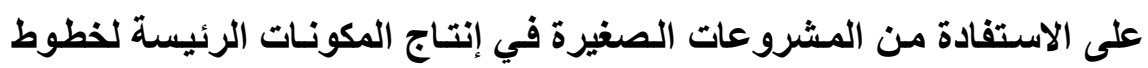

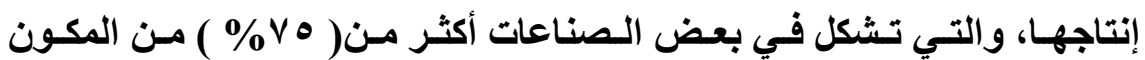
الرئيس.

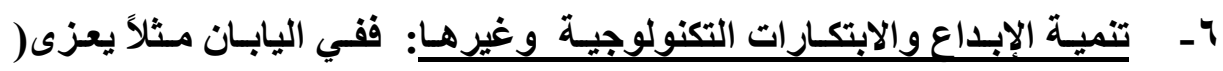
r\%

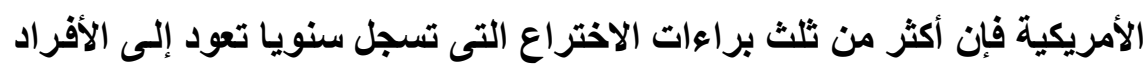

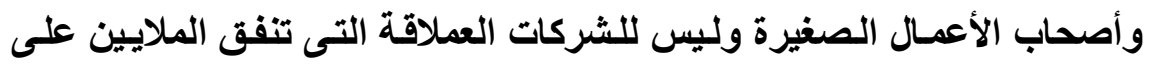
البحث والتطوير، كما أن أكثر من ربـع براءات ولات الاختراع التى تسجل في الدول المتقدمة صناعيا تسجل من قبل أصحاب المشروعات الصغيرة.

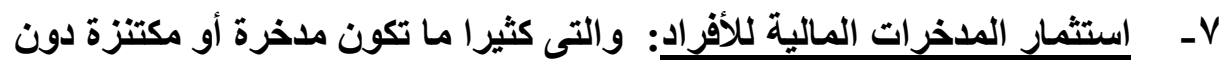

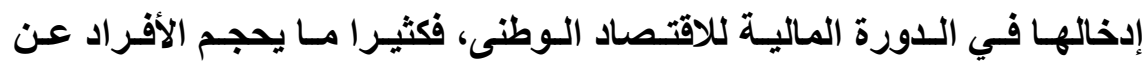
المساهمة في بعض المشروعات الكبيرة التى لا يملكون معلومـات عنها ولن يكونوا بطبيعة الحال ممن لهم القدرة على التأثير فيها أو ممن يساهمون في لهي إدارتها، وذلك بفعل حجم المساهمة البسيطة التي تمنحها لهم قدراتهم المالية،

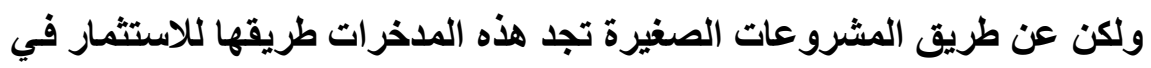

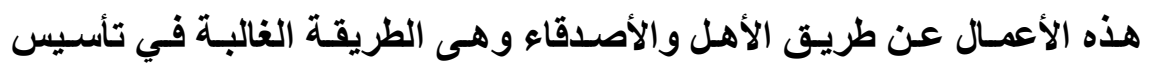

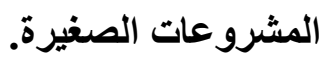


A- تنمية وحماية الصناعات التقليدية: تحظى بقبول شديد للدى العديد من شعوب

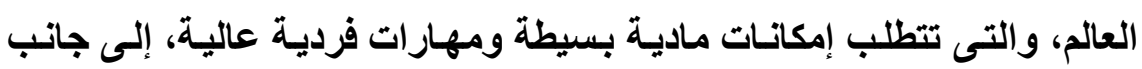
كونها تغطي مدى بـالغ التنوع والاتساع مثل:تصنيع الغذاء والغزل والنسيج

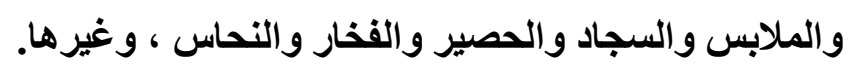

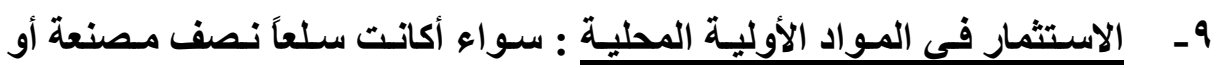
خامات غير مستثمرة. • 1 - تلبية منطلبـات السوق المحلية : خصوصاً في البلدان النامية التي تعاني من صغر حجمها ونطاقها الضيق وانخفاض القدرة الثرائية لاى الأفراد.

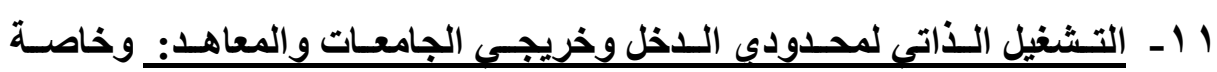
التخصصات التقنية والفنية، حيث إن ديمقراطية التعليم في جميع مراحله أفضت التئي إلى تزايد كبير في أعداد قوة العمل الجديدة والثابة من حاملى الشهادات العليا

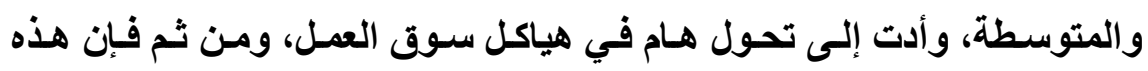

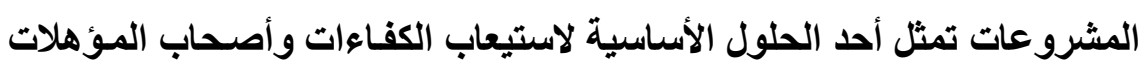

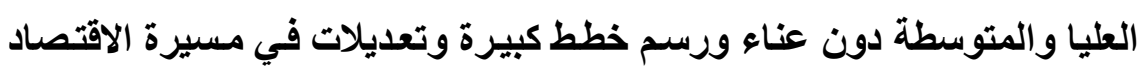
الوطنى.

r 1 - تحقيق الاستقزار الاجتماعى والسياسي: خصوصا وأن لايها القدرة على إعطاء

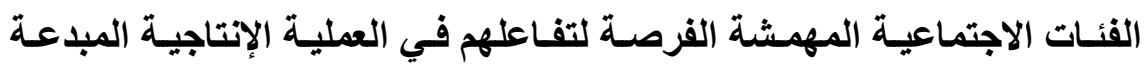

$$
\text { والتعبير عن ذواتهم وطموحاتهم. }
$$
ب 1 - تفعيل دور المـرأة في الأنشطة الاقتصادية والاجتماعيـة المختلفة: بمـا يعزز دورها الريادي والاجتماعي، فكثيرمن المشروعات الصغيرة تناسب إلى حد كبير

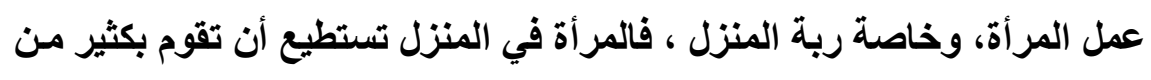

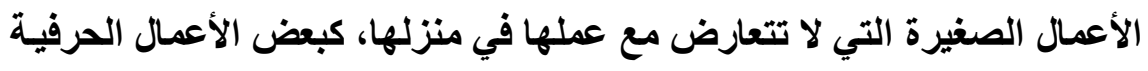
وغير ها. 
ع ا ـ تقويــة العلاقـات الاجتماعيـة: مـن خـلال التفاعـل المـستمر بـين أصـــاب

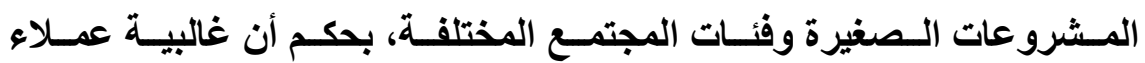
المشروعات الصغيرة محليين وبحكم الروابط القائمة بين العاملين فيها. ه - خلق المنافسة بينها وبين المشروعات الأخرى سواء المتوسطة أم الكبيرة:

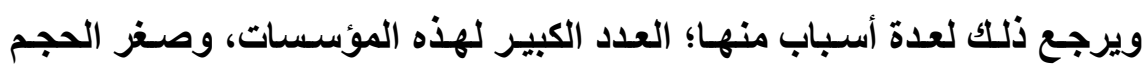

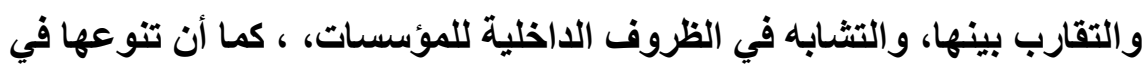
كافة المجالات لا يجعلها تقتصر في عملها على جانب محدد من الاقتصاد، فهى فلى فئ تلبى حاجات المستهلكين الخدمية والإنتاجية على حد سواء وفي جمئ عليع الأمساكن، بما يتناسب مع تللك الاحتياجات وأذواق المستهلكين.

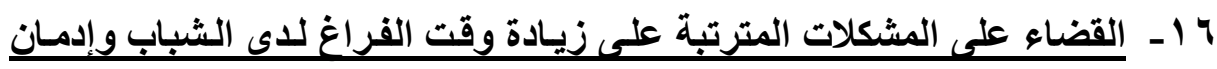

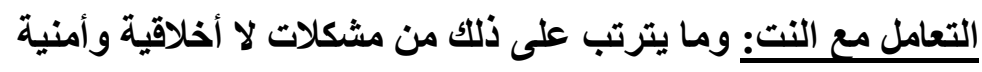
مما سبق يتضح أن المشروعات الصغيرة يمكن أن تلعب دورا كبيرا في تحقيق

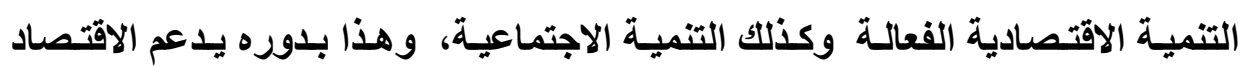
القومي ومن ثم زيادة دخل الفرد، وتحقيق السلام الاجتماعي. وبعد الاتتهاء من توضيح ماهيـة المشروعات الصغيرة وأهميتها الاقتصادية،

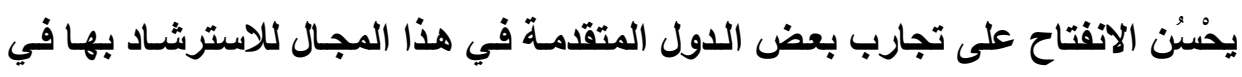

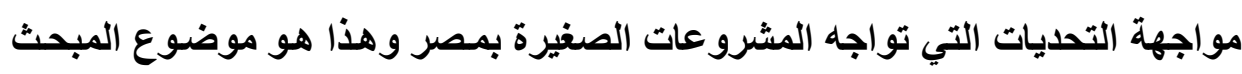




\section{المبحث الثالث}

\section{التجربة الماليزية والهندية للنهوض بالمشروعات الصغيرة والدروس المستفادة منذها}

من المفيد هنا الاطلاع والاستفادة من تجارب بعض الدول الأخرى والتى نشطت

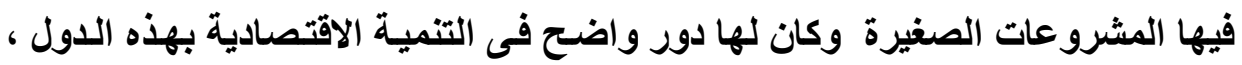

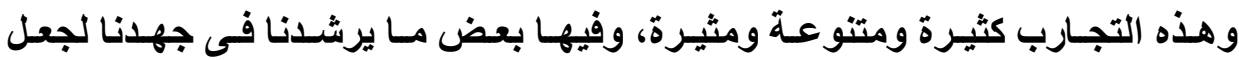

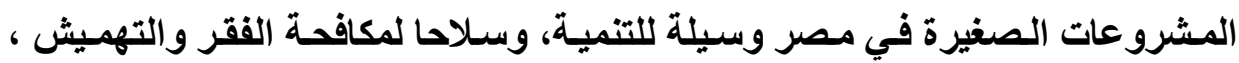
ومجالا للحد من البطالة ، خاصة بين فئات الثباب ، والقوى العاملة من الإناث . وتم اختيـار تجربـة كـلا مـن ماليزيـا والهندـ؛ فماليزيـا نجحت فـى تطوير هذه

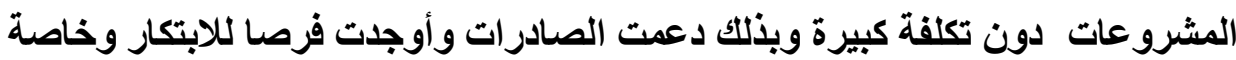
فى مجـال الخدمات والاقتصاد الرقمى وحققت جودة عاليـة مـع إنتاجية مرتفعة، كمـا

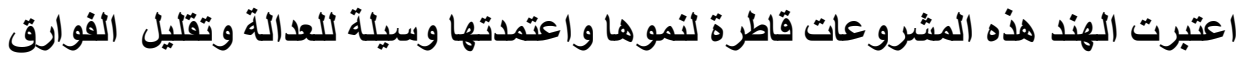

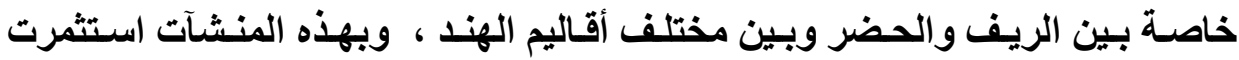
المعرفة لتصبح الهند قطبـا فى تصدير خدمات التقتيـة الرفيعة فـى الاتصـال والنظم والمعلوماتية ، وفيما يلي عرض لهاتين التجريتين.

أولا: التجربة الماليزبية

لعل من أبرز التجارب الاقتصادية الناجحة ، والتي حـازت على اهتمـام وتقدير

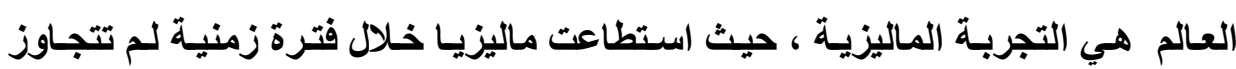

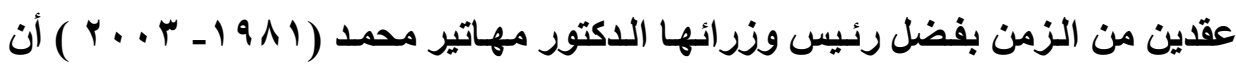
تتحول من دولـة زراعية تعتمد على إنتاج وتصدير المواد الأولية ، واستهلاكية لكل

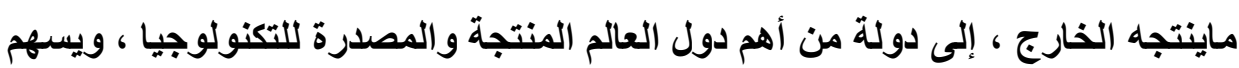


قطاع الصناعة فيها بنحو ( 9 \% ) من الناتج المحلي الإجمالي ، ولتحتل ماليزيا مكانـة

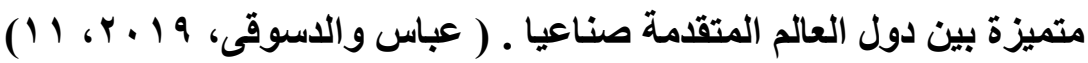
ويعد الاقتصاد المـاليزي اقتصاداً صناعياً وتسويقياً حديث النشأة؛ حيث يشغل الاقتصاد الماليزي المرتبة الخامسة والثلاثين ضمن أكبر مجموعات الاقتصاد العالمي،

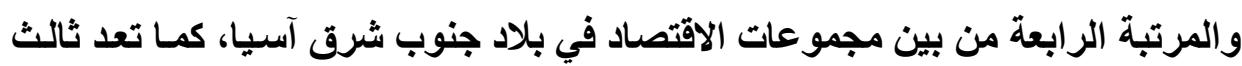

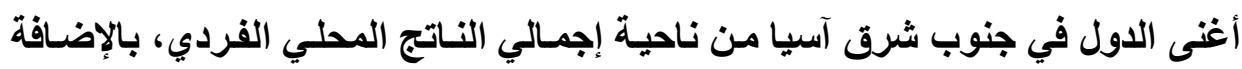

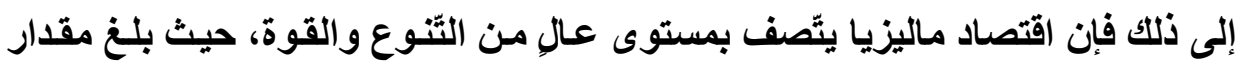

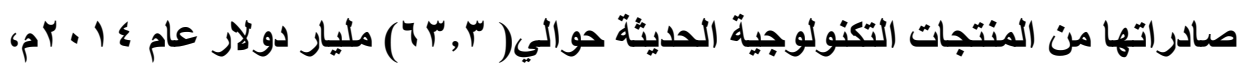
والذي يعتبر ثناني أكبر مقدار بعد دولة سنغافورة، هذا إلى جاتب كونها ثاني أكبر مصدر

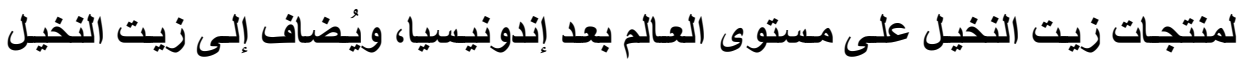

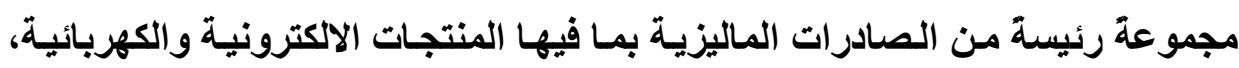

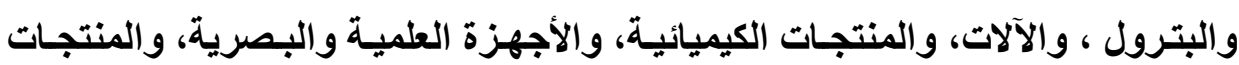
الخشبية والمعدنية.(Sawe,2017)

ويوجد في ماليزيا أكثر من ( . . •) آلاف شركة أجنبية (مملوكة لأثخاص او

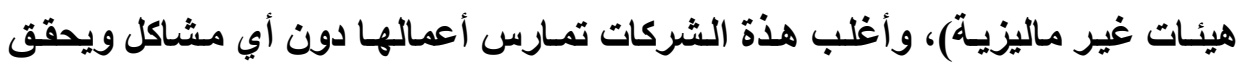

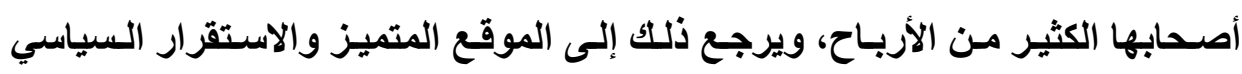

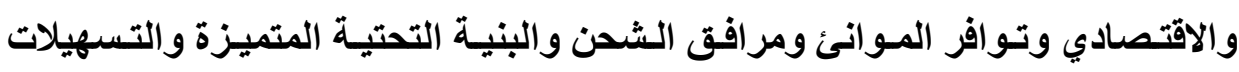

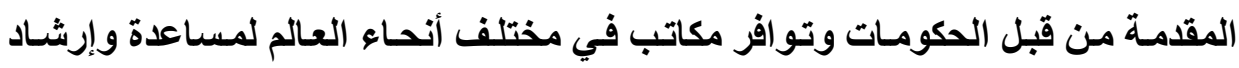

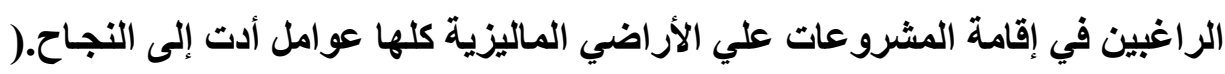

(https://small-projects.org/\%D8\%A7\%D9\%84

لقد كان للمشروعات الصغيرة دور كبير فى تحقيق ونجاح عملية التنمية فى إنى

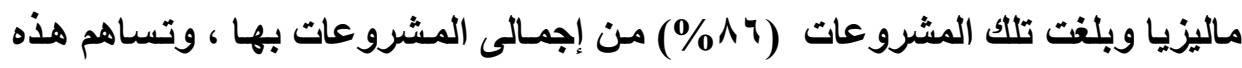

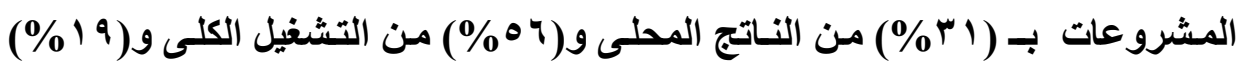

( Moh,2006,25). من قيمة الصادرات 


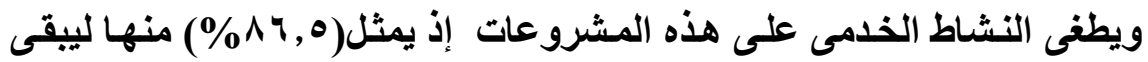

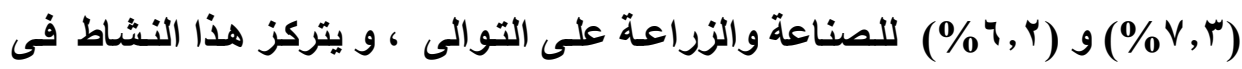

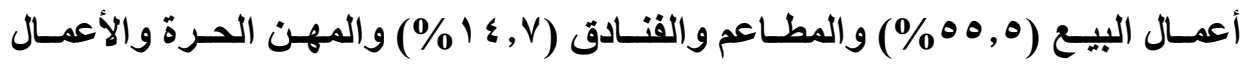

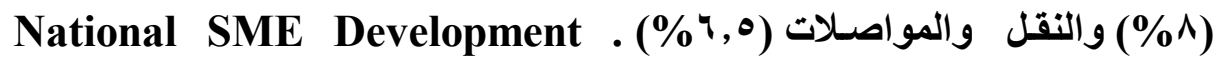

(council,2010,21)

وتم الاهتمسام بهذه المسشروعات ووضعها ضـمن خطط التنميـة الشثاملة منـذ

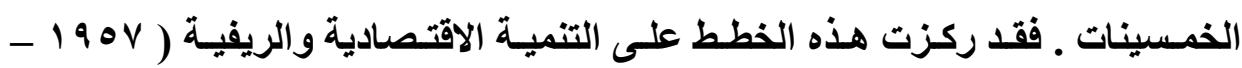

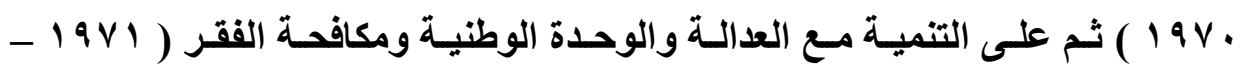

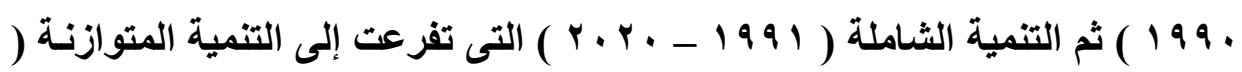

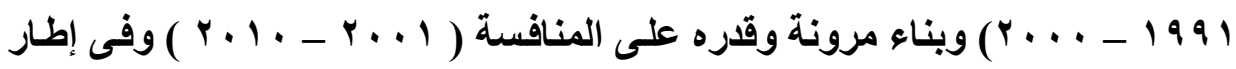

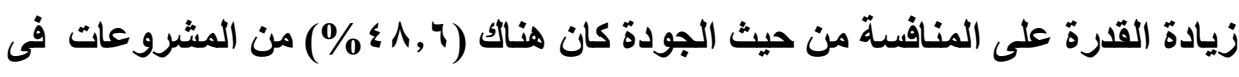

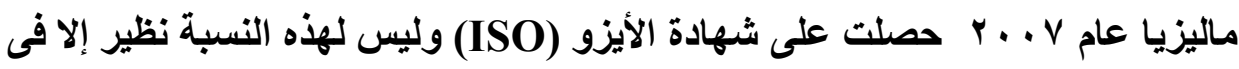

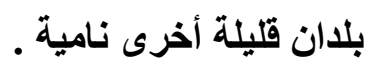

(bttp:/data.worldbank.org/indieator/Ic.FRM.ISOC.ZS)

ومن أهم المبادرات الحكومية لدعم المشروعات الصغيرة كاتت من خلال مجلس وطنى يشرف على تنمية هذه المشروعات National SME Development ) و council )

- - العمل على تحسين البنية الأساسية المادية وتتلك الخاصة بإدارة المعلومات ومن

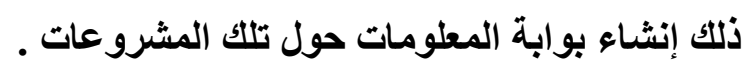

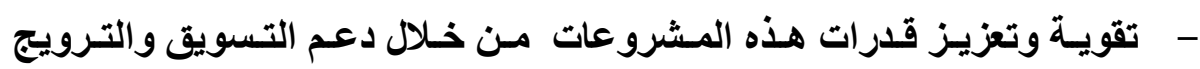

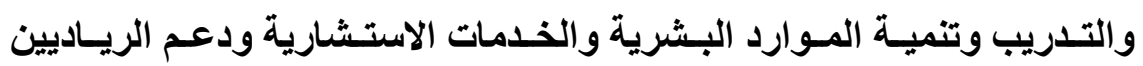

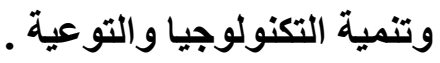


- - القيام بتمويل هذه المشروعات مـن الموازنـة الحكوميـة وبلـغ إجمـالى تمويلها

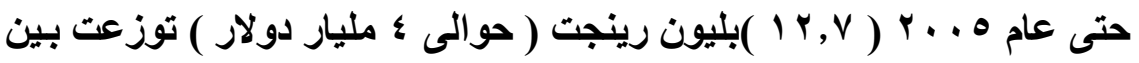

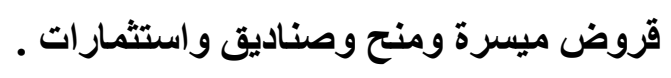

ومـا يميز التجربـة الماليزيـة هو الاهتمـام الحكومى بالمشروعات الصغيرة من

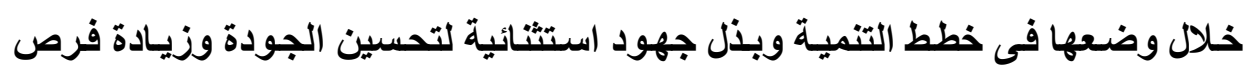

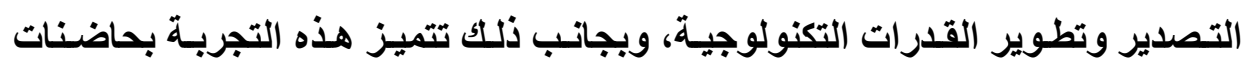
الأعمال خاصة التكنولوجية منها، حيث بدأ تبنى الحاضنات من قبل الجامعات والمر واكز

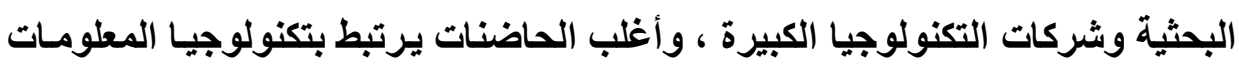

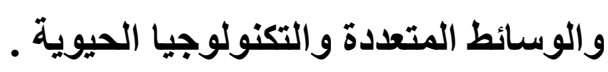

والحكومة هى الراعية لهذه الجهود خاصـة من خلال مركز حاضنات الأعمـال

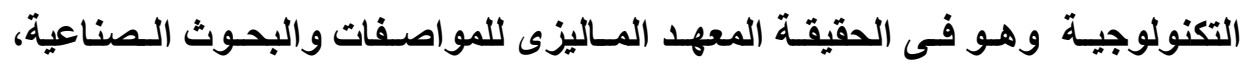
ويتولى هذا المركز رعاية حاضنات الأعمـال والذى بـأ بمرحلة التميـة الرياديـة (رفع

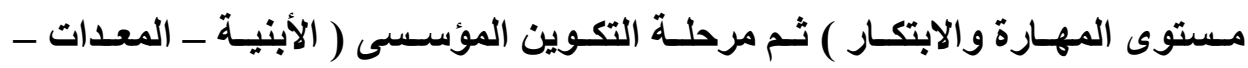

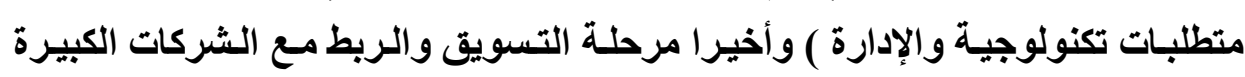

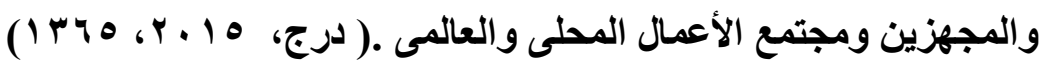
وتعد البنوك هى الممول الرئيس لهذه المشروعات بـاختلاف أنواعها ، حيث

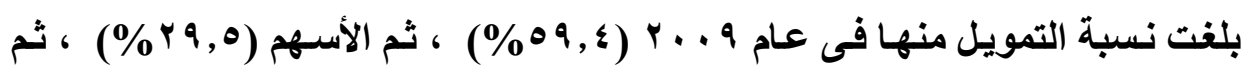

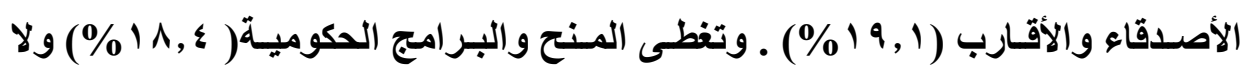

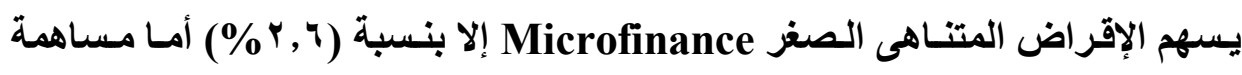

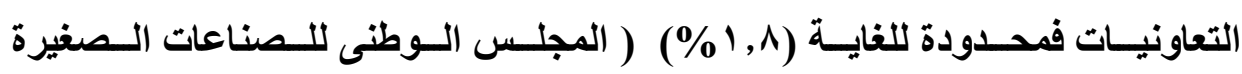

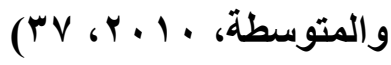
وماليزيا بفضل جهودها فى التنمية الثاملة المتكاملة تبوأت موقعا جيدا فى كل المؤشرات والمقاييس مقارنة بدول العالم الأخرى . 


\section{ثانيا: التجربة الهندية}

تعتبر التجربـة الهندية في التنمية، واحدة من أكثر التجـارب التي أثنارت جدلا كبيرا، بشأن تمكن الهند من تحقيق طفرة كبيرة في التنمية، علي الرغم من ارتفـاع

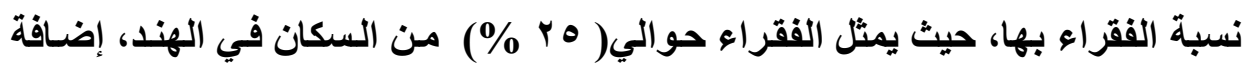

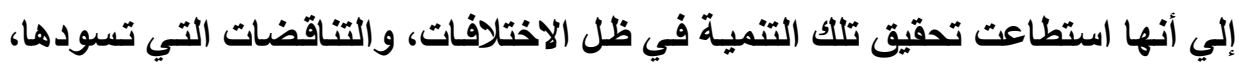

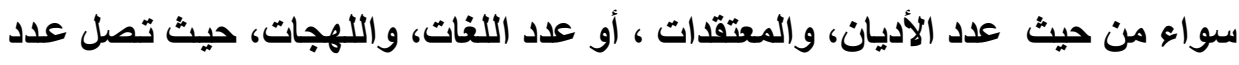

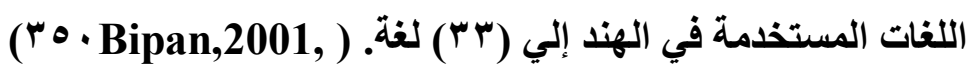
و مر الاقتصاد الهندي بمرحلتين هـامتين: الأولـي مرحلة الانعزال عن العـالم،

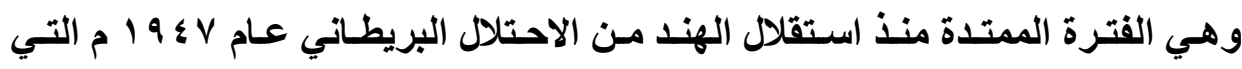

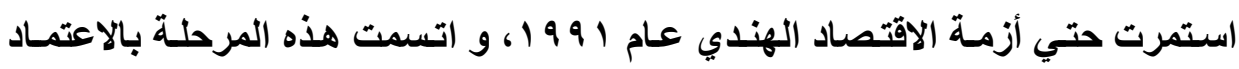

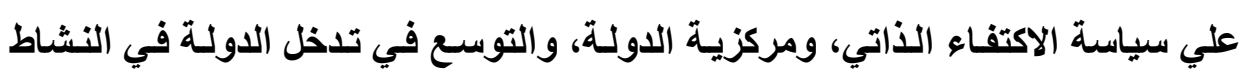

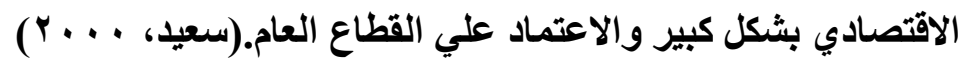

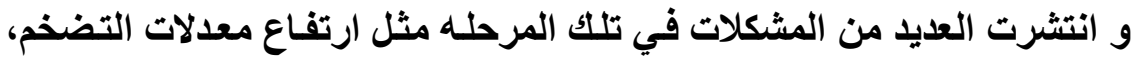

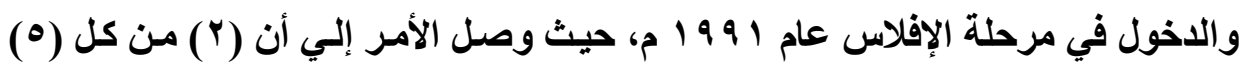

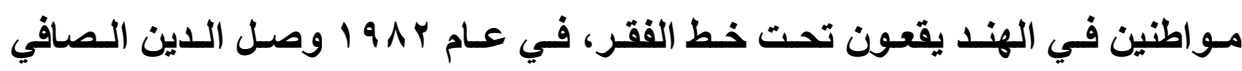

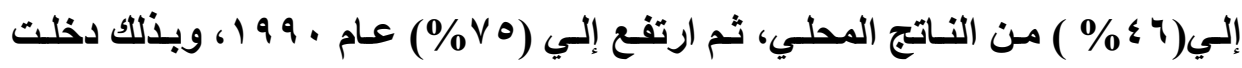

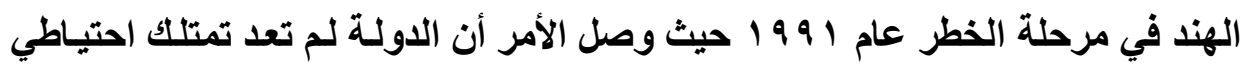

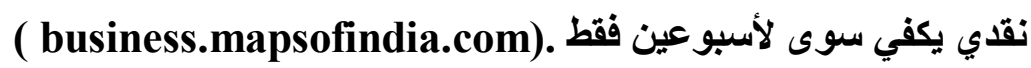
ثم انتقلت الهند إلي مرحلة أخري- الثاتيةــ متناقضة تماما عام الو9 19، ودخلت

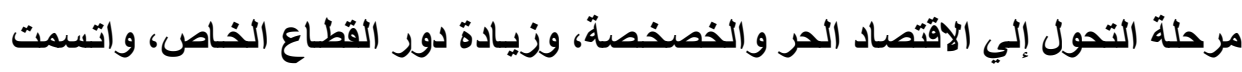

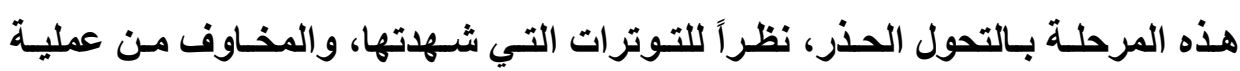

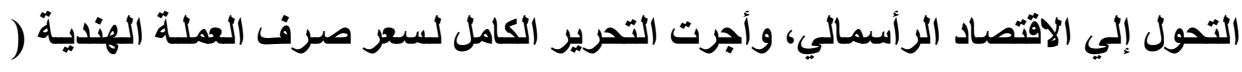
الروبية ) عام ب9 9 1 ، واتسمت هذه المرحلة بالانفتاح الاقتصادي، وإلغاء القيود علي 


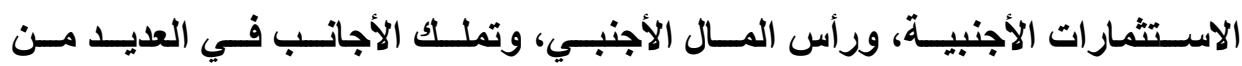

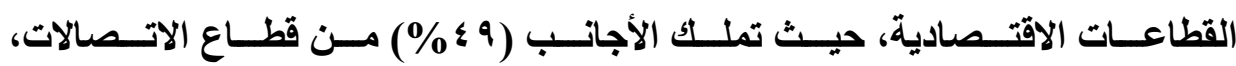

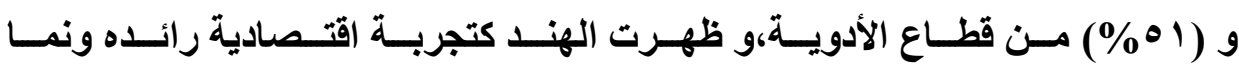

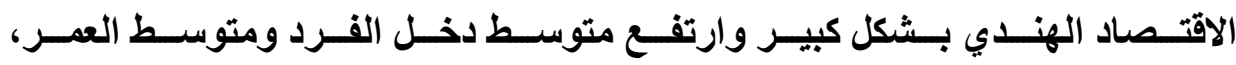

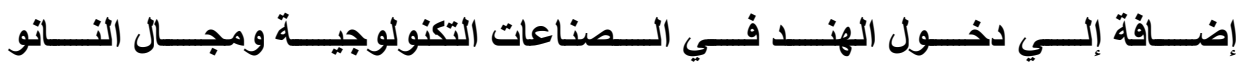

(web.worldbank.org) تكنولوجي ( ولكى تحقق الهند تلك الطقرة الهائلة فى عملية التنمية الاقتصادية والخروج من

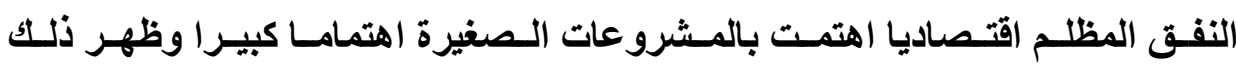

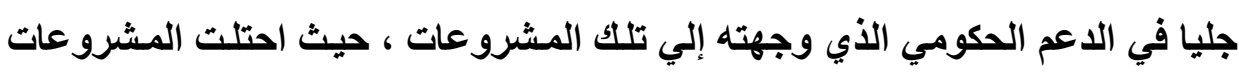

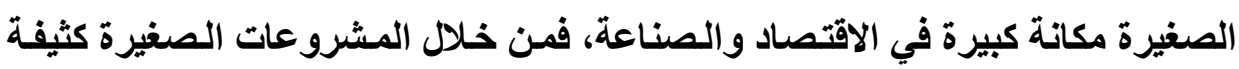

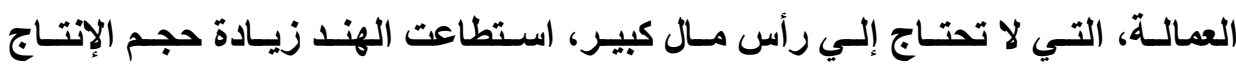

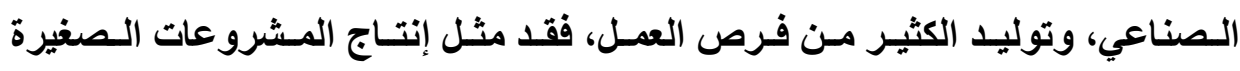

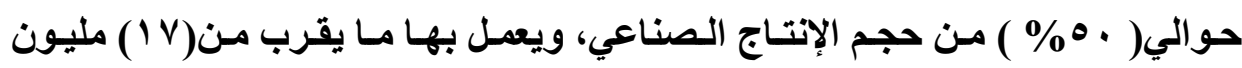

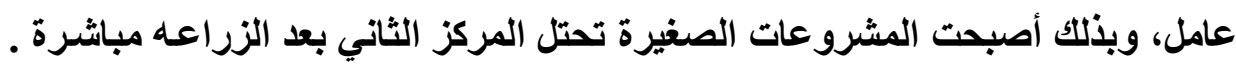

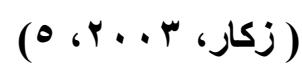

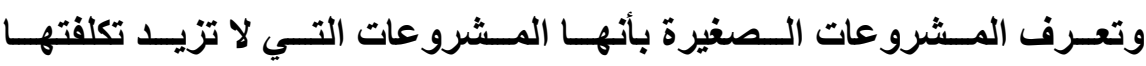

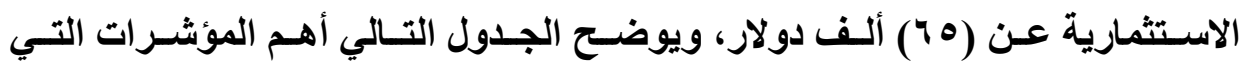

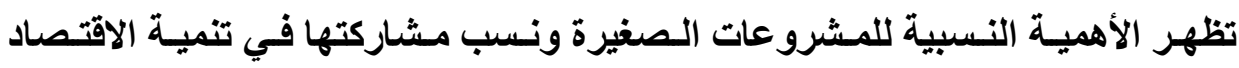
الهندي. 
جدول (1) ) نسب مشاركة المشروعات الصغيرة في

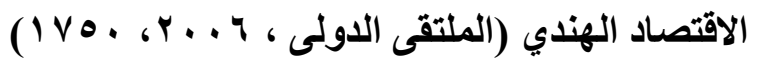

\begin{tabular}{|c|c|}
\hline نسبة المشاركة & 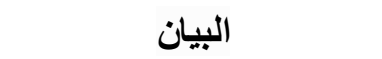 \\
\hline$\% 30$ & الناتج المحلي الإجمالي \\
\hline$\% 45$ & إجمالي الصادرات الصناعية \\
\hline$\% 95$ & عدد المشروعات الصناعية \\
\hline$\% 40$ & إجمالي الإنتاج الصناعي \\
\hline 3.2 مليون وحدة & عدد الوحدات المسجلة \\
\hline 18 مليون & العمالة \\
\hline
\end{tabular}

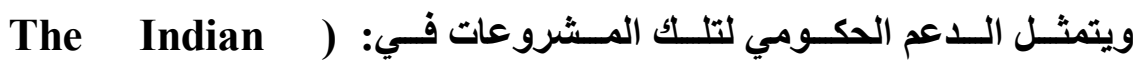

(government report ,2015,56

ا. توفير التمويل اللازم لتلك المشروعات بأسعار فائدة منخفضة، لضمان استمرار الإنتاج .

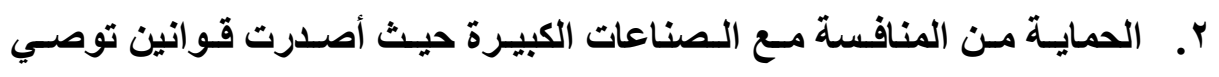

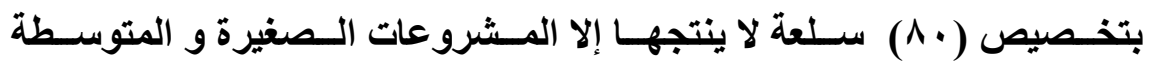

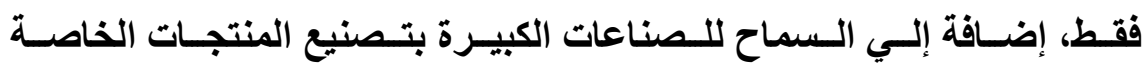
بالمشروعات الصغيرة، بشرط تصدير (•٪\%) من ذلك الإتتاج، بهدف تدعيم

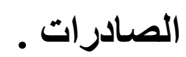
r. توفير البيانات، والمعلومات اللازمـة للمشروعات الصغيرة عن حالة الأسواق، واحتياجاتها، إضافة إلي تطبيق أسلوب العناقيد الصناعية الذي ساعد علي تجمع 
المشروعات الـصفيرة، والـربط بينهـا، وإنتـاج منتجـات مكملـة للمسشروعات الكبيرة ومغذية لها، إضـافة إلي المساعدة في عمليـات التسويق الملائم لإنتاج

$$
\text { المشروعات الصغيرة. }
$$

؛. تلعيم البنية الأساسية لتلك المشروعات، مع الاهتمام بالتدريبات اللازمة للعمال،

$$
\text { وتوجيه الدعم الإداري والقني. }
$$

•. العمل علي إنشاء وتعديل القوانين بما يتوافق مع احتياجات تلك المشروعات. 7. إنشاء جهاز ( إدارة الصناعات الصغيرة والريفية) الذي يعمل علي تعظيم دور المشروعات الصغيرة في الاقتصاد القومي، والعمل علي التصدي لكل التحديات والمعوقات لتتلك المشروعات. V. . توجيه الاعم المادي لها حيث أنشأت الهند صندوق لاعم المشروعات الصغيرة،

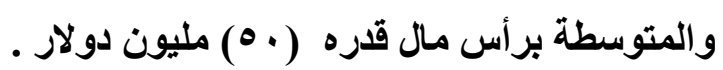

^. إقامة نظام للإعفاء الضريبي الخاص بالمشروعات الصغيرة ، الذي يعتمد علي أن تقـل نـسبة الإعفـاء الـضريبي بـشكل تـدريجي مـع الزيــادة في رأس مسال المشروع .

9. توجيه العديد من الإعفاعات الضريبية، والمزايـا الأخرى، في المنـاطق الريفية،

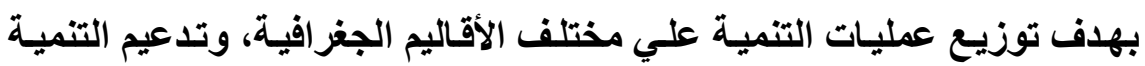
الاقتصادية بتلك المناطق. • 1 ـ إقامـة شبكات الطرق، والميـاه، والكهربـاء، و وغيرهـا، بهـدف المسساعدة علـي تطبيق أسلوب العناقيد الصناعية، والمجمعات الإنتاجية.

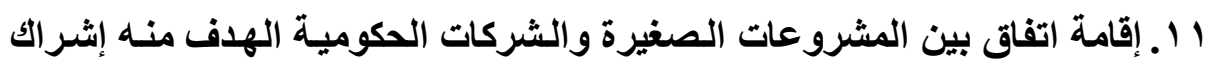

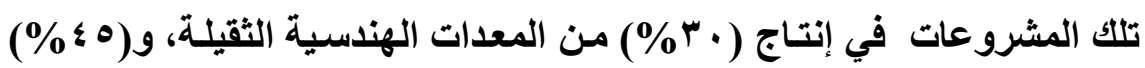

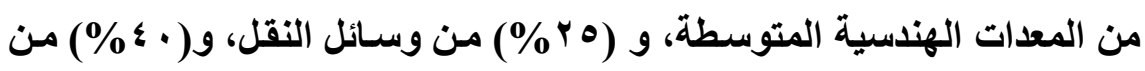

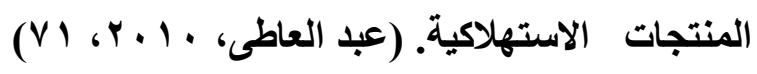


ومـن الجدير بالذكر أن تلك المشروعات تقوم بتشغيل (9 ه) مليون هندى ، ويقدر عدد هذه المشروعات بـ († Y) مليون وحدة إنتاجية ، وتتتج هذه المشروعات

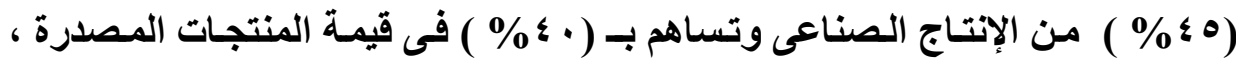

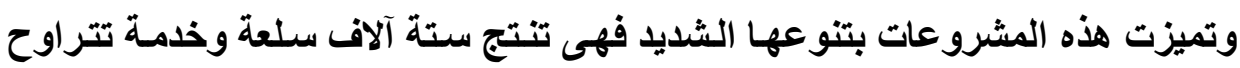
بين الصناعات التقليدية إلى منتجات التقنية الرفيعة ، وهى توجد فى الريف كمـا توجد

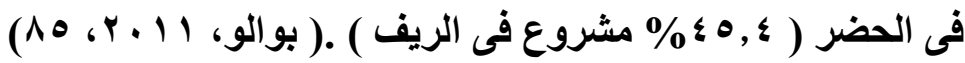

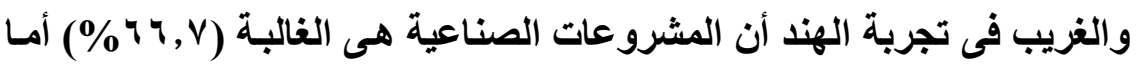
الخدمات فهى تمثل (\% Y V ) عكس تجربة ماليزيـا ، وهنـاك نسبة هامـة تقوم بعمليات الصيانة والإصـلاح (r, צ 1\%) ، وأغلب هذه المشروعات هـ ضـمن القطساع غير

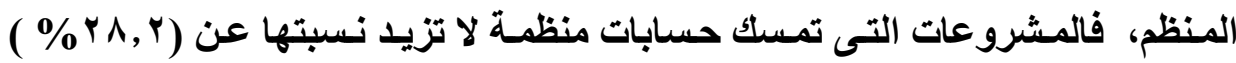

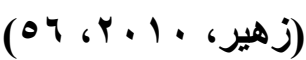
لقد أثبتت الدراسات فى الهند أن المشروعات الصغيرة هى المولد الأكبر لفرص

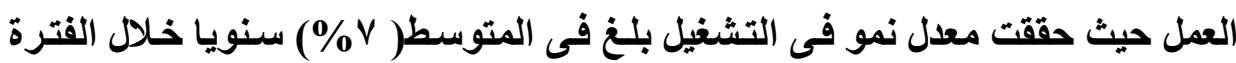

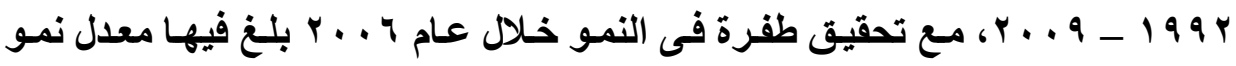

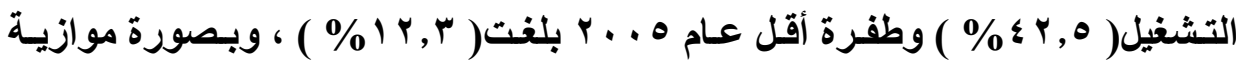

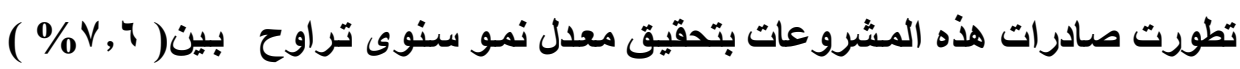

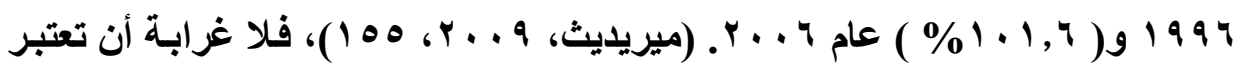

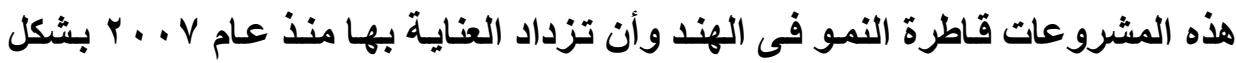
خاص ، وقد أصبح هذا شكلا مميزا للتجربة الهندية . جدير بالذكر أن النجاح الذي حققته تجـارب كلا من دولتى ماليزيـا والهنــ في مجال دعم وتظوير المشروعات الصغيرة هو حصيلة مجموعة من الخطط والسياسات

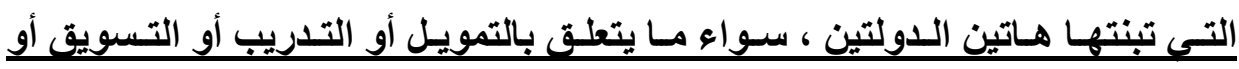


التشريع أو الإعفاء الضريبي أو تبنى حاضنات الأعمال والحماية من المنافسة وتطبيق

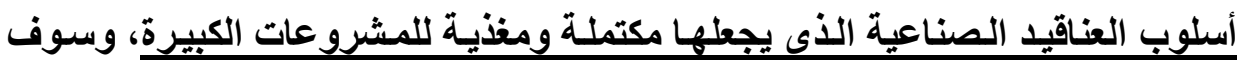
يظهر ذلك في المحور الخـامس مـن البحث والخـاص بسبل النهوض بالمشروعات الصغيرة في مصر.

وبعد إلقاء الضوء على تجربـة دولتى ماليزيـا والهنــ باعتبار همـا مـن أفضل

الدول التى تعاملت مع المشروعات الصغيرة، يحْسّن تسليط الضوء على المشروعات

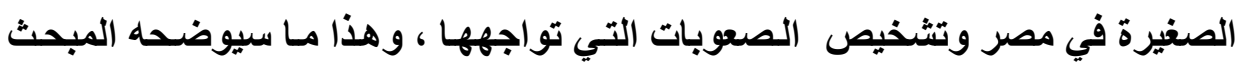




\section{المبحث الرابع}

\section{المشروعات الصغيرة فى هصر

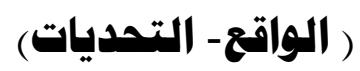

بعد الوقوف على الإطار المفاهيمى للمشروعات الصغيرة، وأهميتها الاقتصادية،

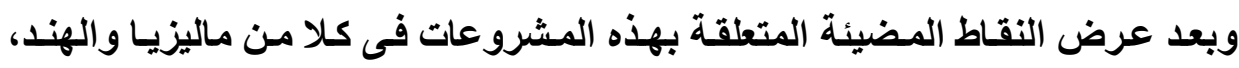

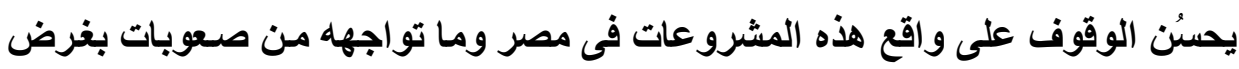

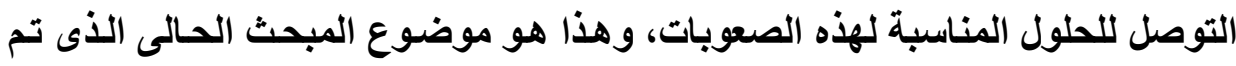
تقسيمه إلى محورين هما: الأول: واقع المشروعات الصغيرة في مصر

الثاني: التحديات التى تواجه المشروعات الصغيرة وفيما يلى شرح لكل منهما المحور الأول: واقع المشروعات الصغيرة في هصر بـأت تجربـة الصناعات الصغيرة في مصر عـام 199 ام مـن خـلال البرنـامج

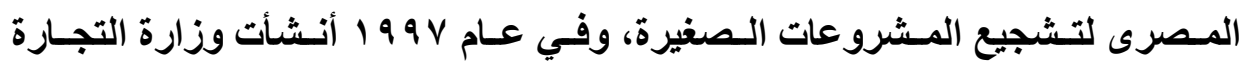
الخارجيـة وحدة المشروعات الصغيرة والمتوسطة، إلى جاتب الإدارة العامـة لشئون

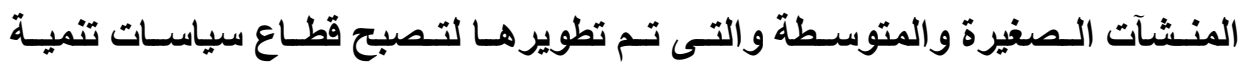
المشروعات الصغيرة وهو مسئول عن وضع إطار من السياسات المشجعة لدعم القدرة

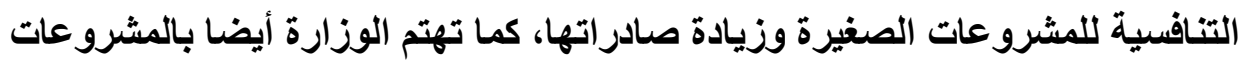
الصغيرة من خلال تنفيذها لبرنـامج تحديث الصناعة وبالتعـاون مـع اتحـاد الصناعات

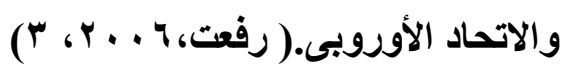


وفي عام 999 1 19 اهتمت وزارة المالية بقطاع المشروعات الصغيرة من خلال مشروع تضمين كافة منشآت الأعمـال داخل القطاع الرسمي، رغبة وفية منها في حصر

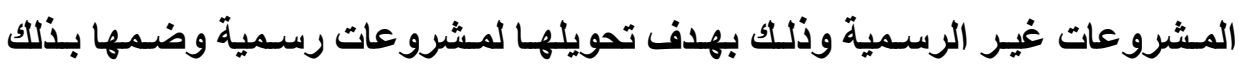

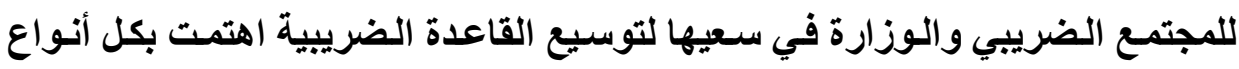
المشروعات الصغيرة الخدمية والتجارية والصناعية والزراعية، وفي نفس العام أصدر

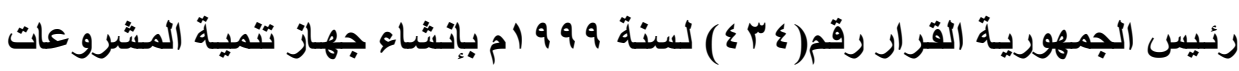

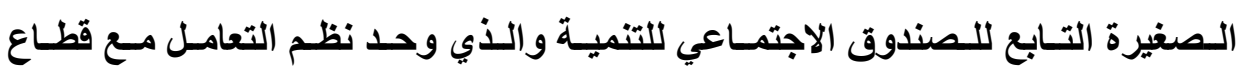

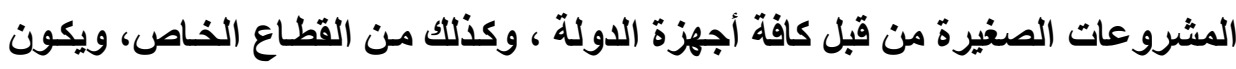

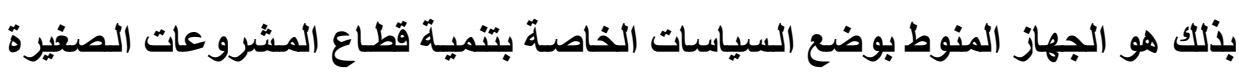

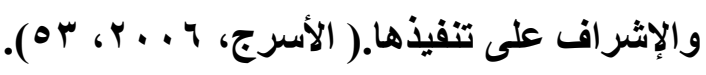

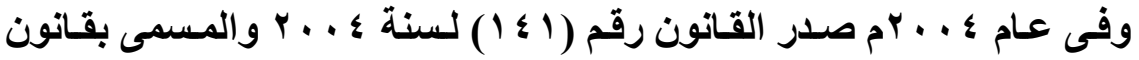

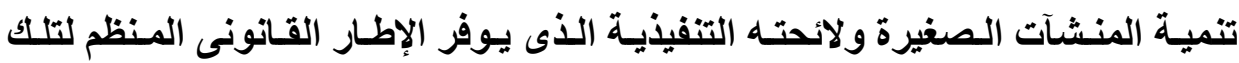

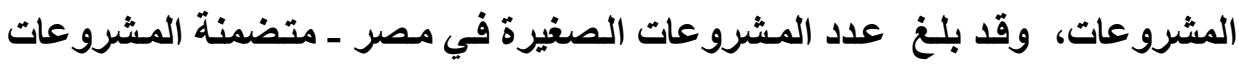

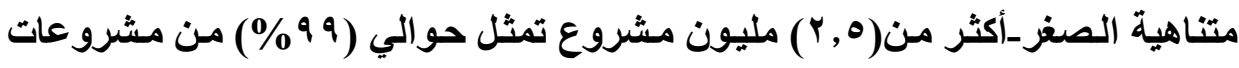

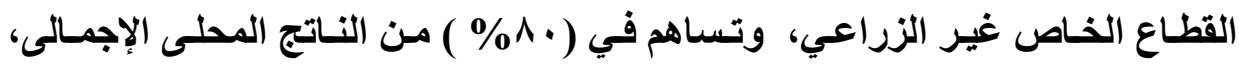

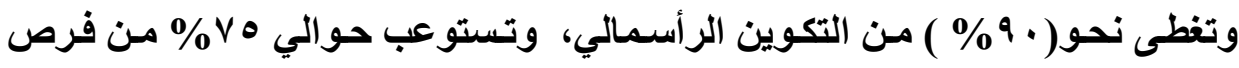

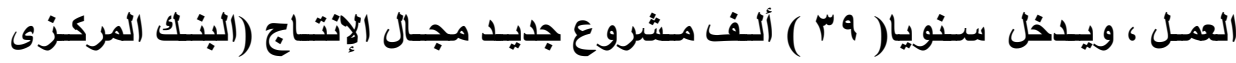

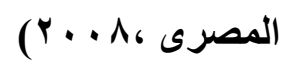

ومن ناحية أخرى تساهم المشروعات الصناعية الصغيرة بنحو( ب | \% م ) من

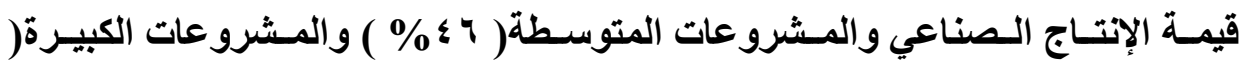

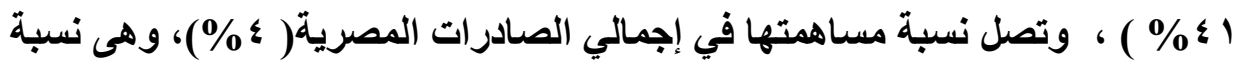

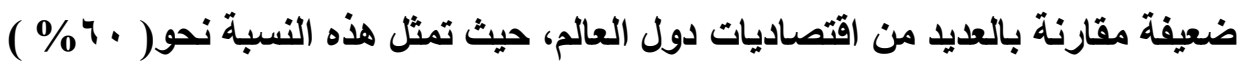

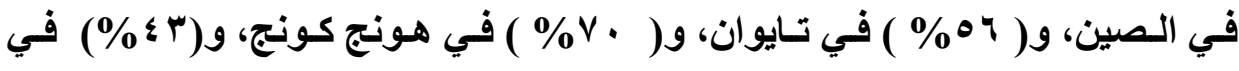

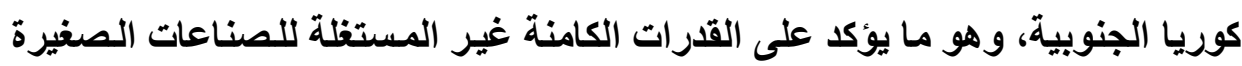


في مصر، والتي يمكن أن تلعب دوراً حاسماً في زيادة الصادرات المصرية. ( مـاهر، http://digital.ahram.org.eg/articles.aspx?Serial=97585\&eid=52

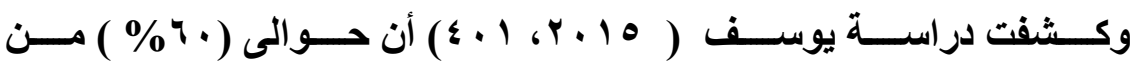

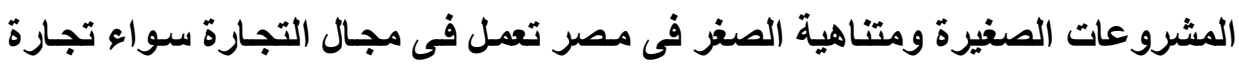

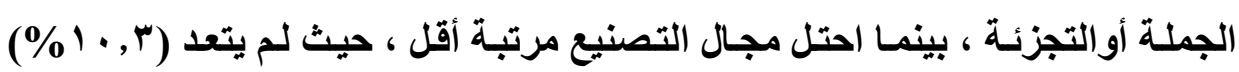

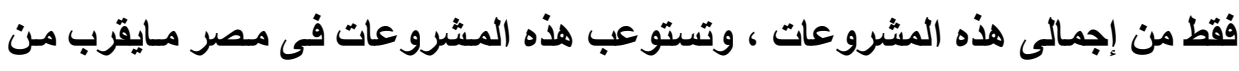

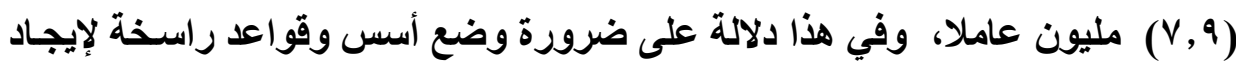

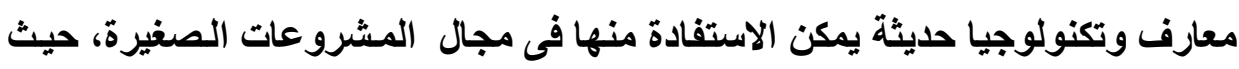
أصبح الابتكار والتقام فى مجال التكنولوجيا هو المحرك الأساسى للتنمية الاقتصادية.

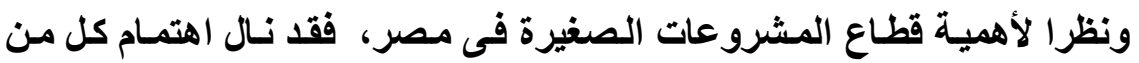

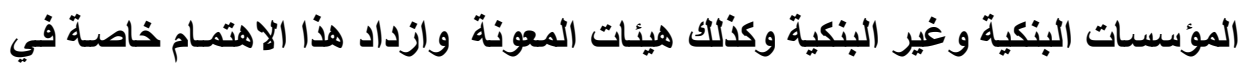

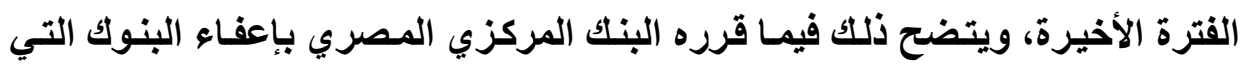

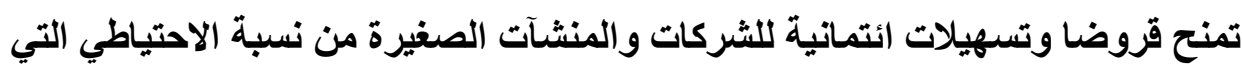

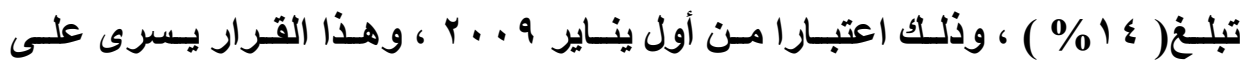

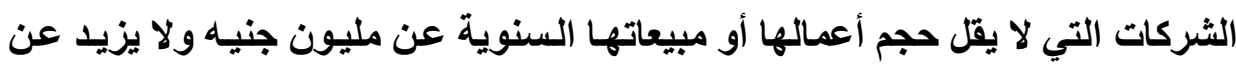

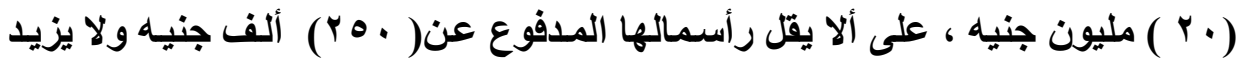

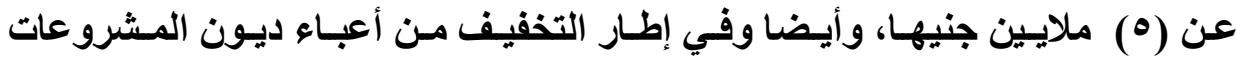

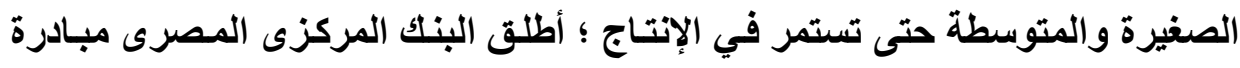

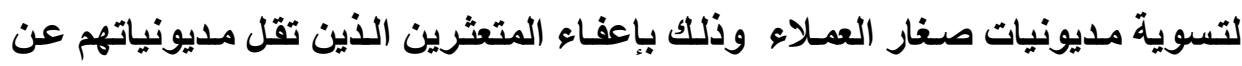

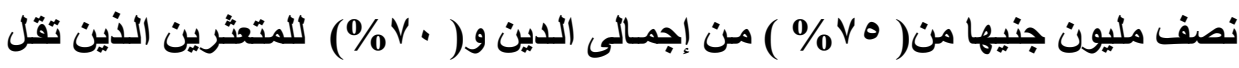

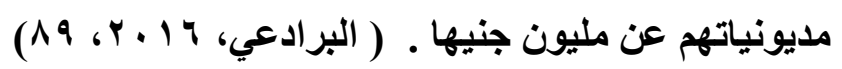

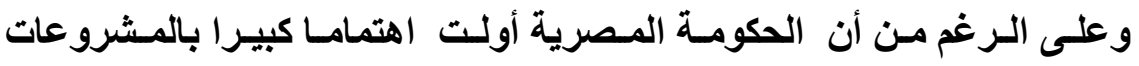

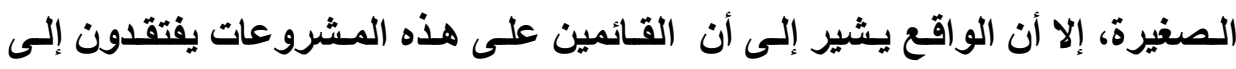

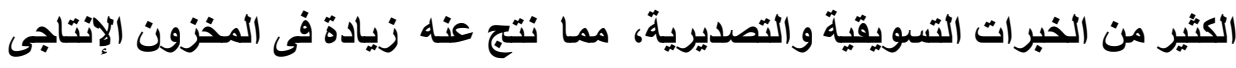


وتضخم أعبـاء التمويـل، ومـن ثم إفـلاس بعض أصـاب تلـك المشروعات الصغيرة وخروجهم من السوق.

وهكا يشير الواقع إلى أن المشروعات الصغيرة فى مصر ليست على المستوى

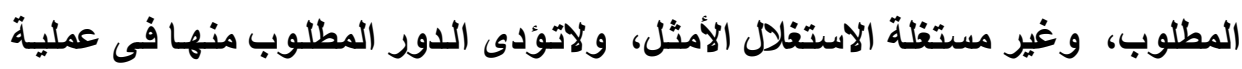

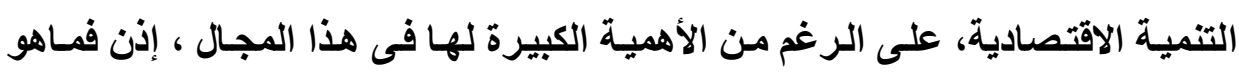

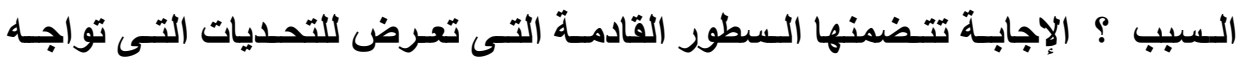
المشروعات الصغيرة في مصر.

\section{الحور الثاني: التحديات التى تواجه المشروعات الصغيرة}

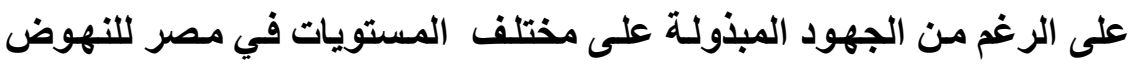

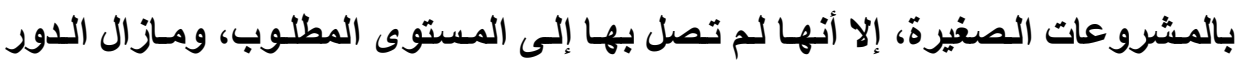

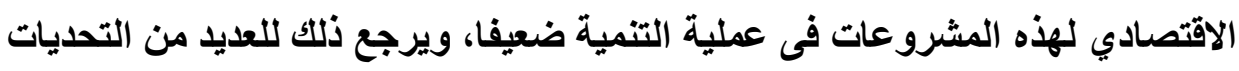

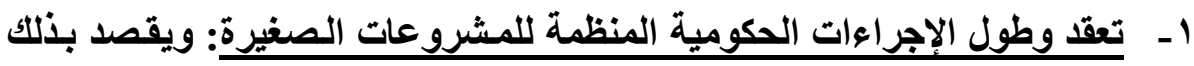

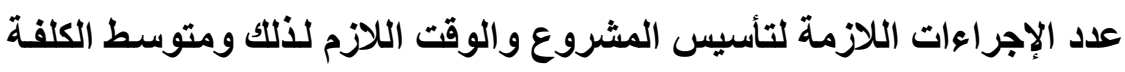

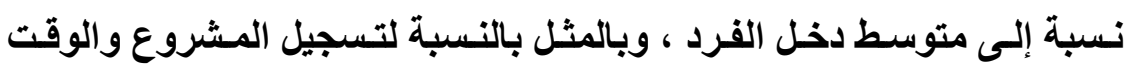
اللازم لذلك ، كما تتضمن عناصر عديدة أخرى مثل النظام المصرفى والبنية

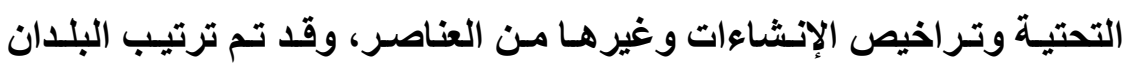

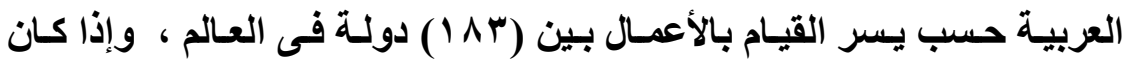

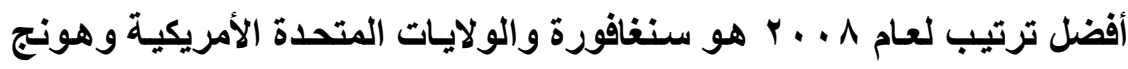
كونج ونيوزيلندا ، فإن ترتيب البلدان العربية بين دول العالم كان على النحو 


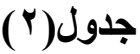

ترتيب البلدان العربية بين دول العالم حسب يسر الإجراءات اللازمة لإنشاء المشروع

(http://data.worldbank.org/indicator/ic.bus.ease.xq) الصغير

\begin{tabular}{|c|c|c|c|}
\hline الترتيب & الدولة & الترتيب & الاولة \\
\hline 117 & مصر & 10 & السعودية \\
\hline ir. & المغرب & 11 & البحرين \\
\hline & الجزائر & $r v$ & قطر \\
\hline Irv & الضفة الغربية وغزة & or & الكويت \\
\hline $1 \leqslant 9$ & السودان & 7. & عُمان \\
\hline 10. & العراق & Vr & تونس \\
\hline $10 \mathrm{~V}$ & جيبوتى & $1 \cdot 1$ & لبنان \\
\hline \multirow{2}{*}{171} & \multirow{2}{*}{ موريتانيا } & $1 \cdot r$ & اليمن \\
\hline & & $1 \cdot \varepsilon$ & الأردن \\
\hline
\end{tabular}

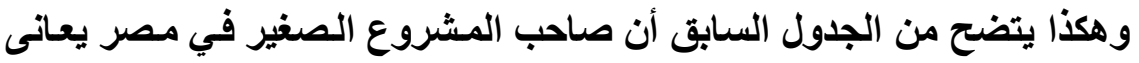

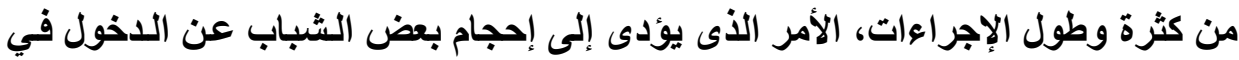

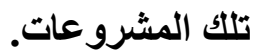

ץ- ضعف قدرة بعض أصحاب المشروعات الصغيرة على إدارتها بالشكل المناسب:

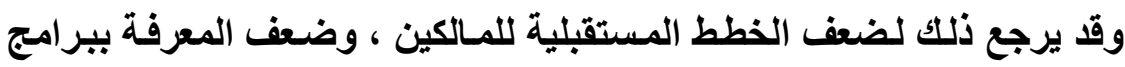

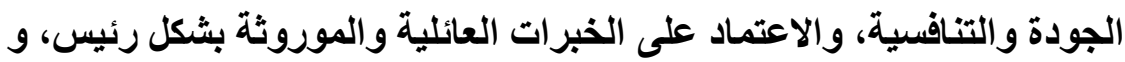

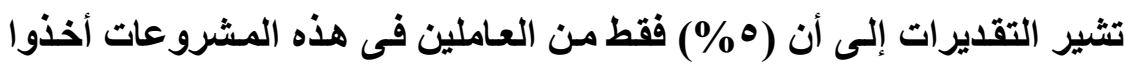

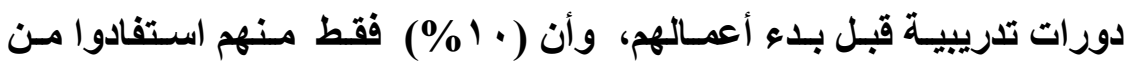

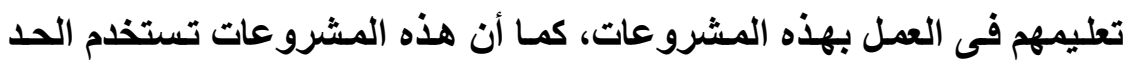

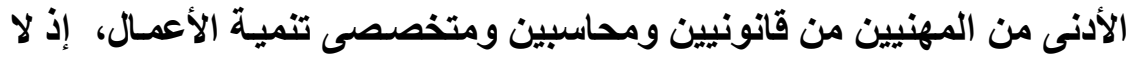

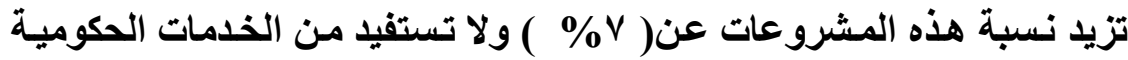




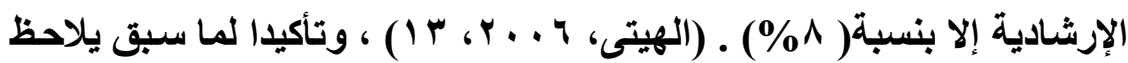

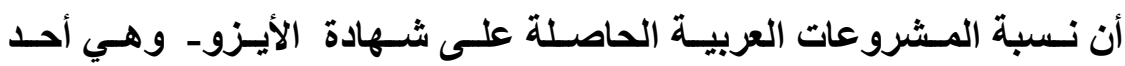

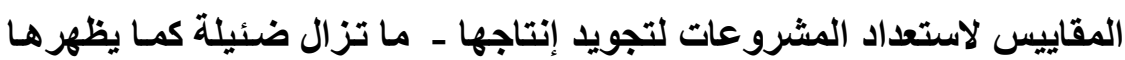
الجدول التالي لمصر ويعض الدول الأخرى ـ

$$
\text { (r) (بدول) }
$$

نسبة المشروعات الحاصلة على شهادة الأيزو

في مصر وبعض الدول الأخرى إلى إجمالي المشروعات( البتك الاولى، 9 . . Y )

\begin{tabular}{|c|c|}
\hline 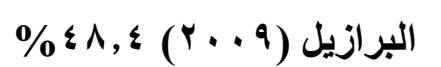 & 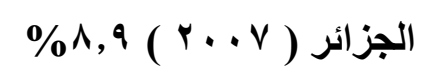 \\
\hline 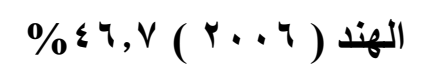 & 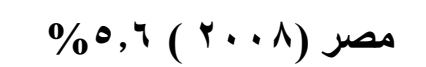 \\
\hline 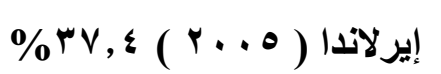 & 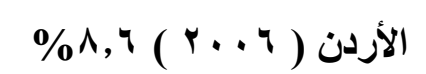 \\
\hline 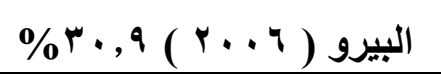 & 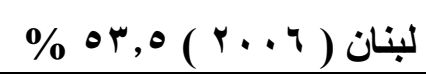 \\
\hline 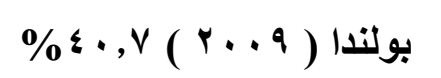 & 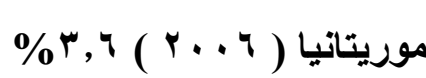 \\
\hline 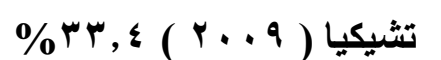 & 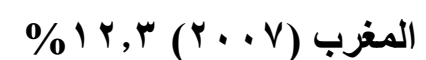 \\
\hline
\end{tabular}

ويلاحظ من الجدول السابق الضعف المتنـاهي للمشروعات التي لها بنية مقاييس الجودة فى مصر والدول العربية باستثناء لبنان.

r- - صعوبة الحصول على قروض ميسرة واعتماد غالبية المشروعات على التمويل الأتى البسيط : تعد صعوبة الحصول على التمويل أحد العوامل الهامة المعوقة لنمو المشروعات الصغيرة، وحسب التقييم الأي أجرته حديثاً مؤسسة التمويل

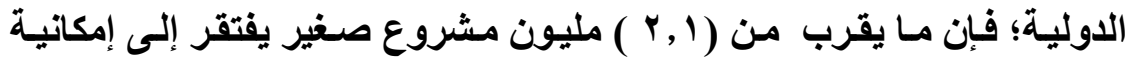

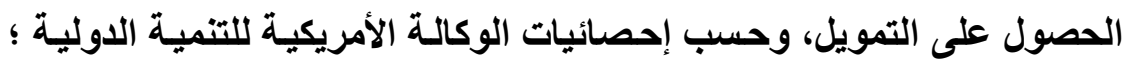


تمثل المشروعات الصغيرة التي لم تحصل على الخدمات النسبة الأكبر(دوابه،

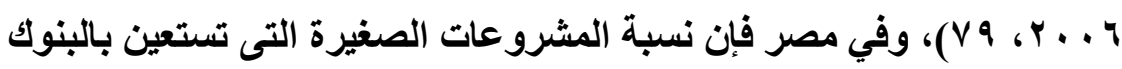

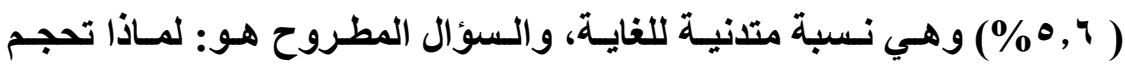

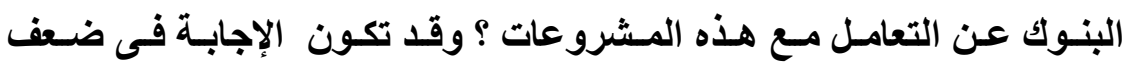
الضمانات التى تقدمها هذه المشروعات للبنوك وتخوف البنوك من ارتفـاع

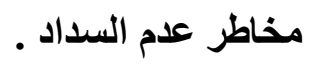

ع - انخفـاض أعداد العمالـة المدربـة و المـاهرة: يعتبر العنصر البشري أحد أهم

عناصر الإنتاج ولذلك فإن نقص العمالة المـاهرة هو من أهم المعوقات التي لهي تواجه المشروع الصغير، ويعود سبب عدم وفرة العمالة المـاهرة إلى تفضيل

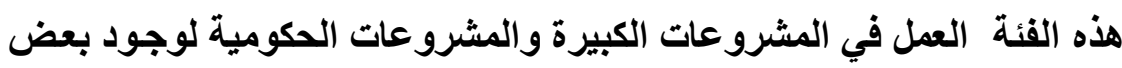
الامتيـازات كالتقاعد والضمان الاجتمـاعي والـصحي، وغير ذلكت مـن المزايـا.

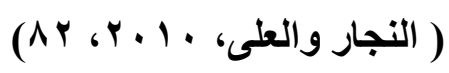

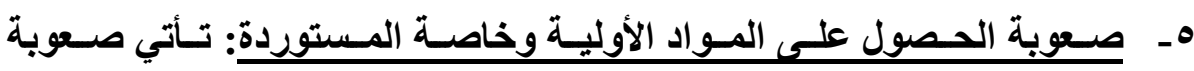

الحصول على المواد الأولية بسبب اعتماد بعض هذه المشروعات على المواد

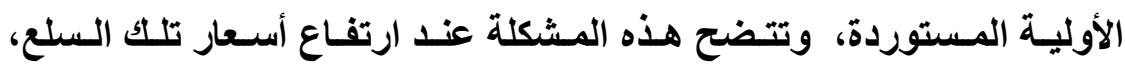

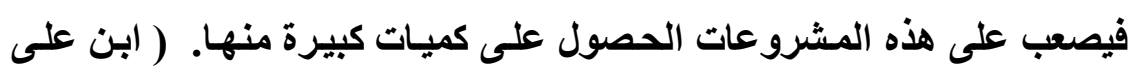

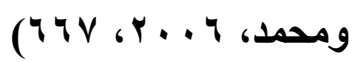

7- المشكلات المرتبطة بعملية التسويق : نظراً لعدم اهتمـام بعض أصحاب هذه

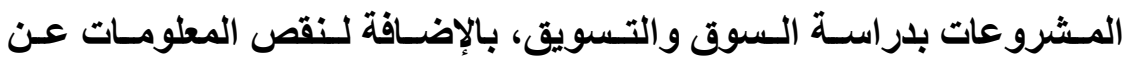

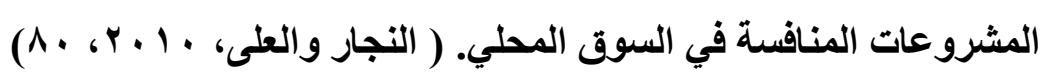

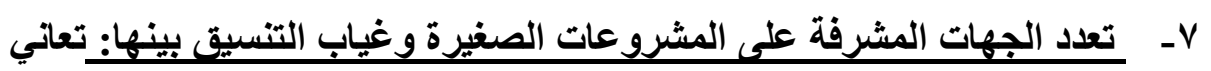

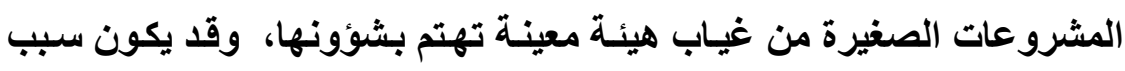

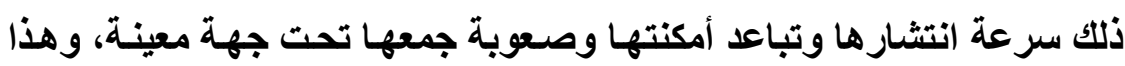


يحرمها في الكثير مسن الأحيـان مسن الحصول على الامتيـازات والتسهيلات، وأيضا مزاحمة المشروعات الكبيرة لها.

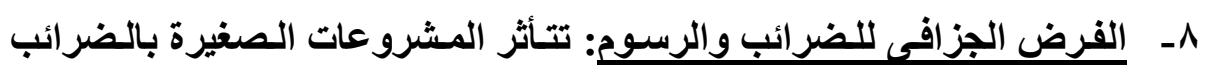
والرسوم أكثر ممـا تتأثر بها المشروعات الكبيرة بسبب شمول هذه الأخيرة

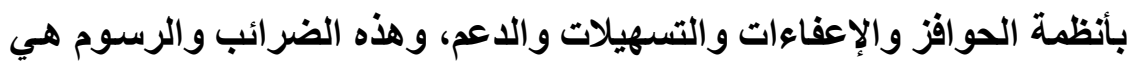

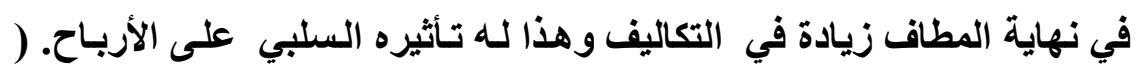

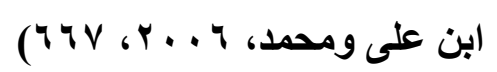
9- تعدد الجهات الرقابية: تعساني المشروعات الصغيرة من مشكلة تعدد الجهات التقتيشية والرقابيـةـ الصحية، والاقتصادية، والضمان الاجتمـاعي، والدوائر

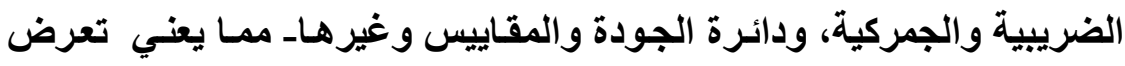

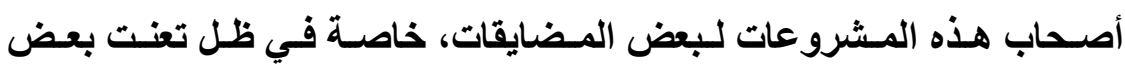

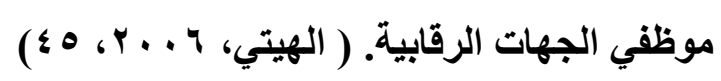

• 1 - تواضع حجم الإنتاج وارتفـاع التكلفة: هنـاك أسباب كثيرة تؤثر في انخفـاض إنتاجية المشروع الصغير منها سوء التخطيط الذي يؤدي إلى عدم تدفق المواد

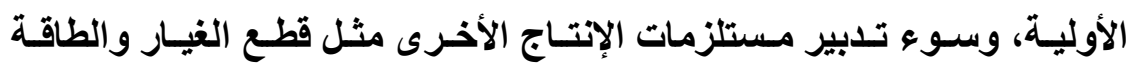

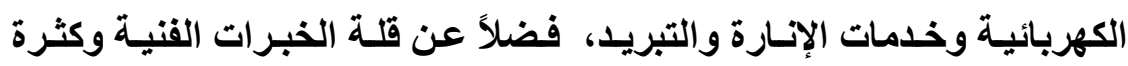

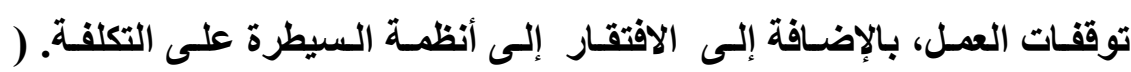

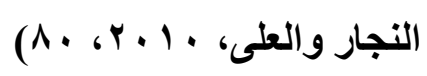

1 اـ افتقاد المنتج- أحيانا_ لمواصفات ومعاييز الجودة: ويرجع ذلتك لاستعمال الآلات

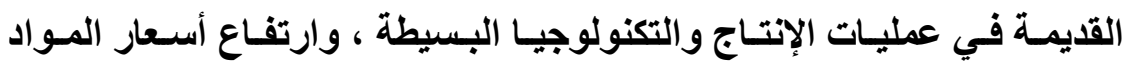
الأولية الجيدة، فضلاً عن صعوبات الاستعانة بـالكوادر الهندسية والعناصر الفنية المدربة ، وعدم وجود مراكز لفحص الجودة والسبطرة النوعية. (دوابه،

$$
(\Lambda \cdot, Y \cdot T
$$


r ا ـقلة الاهتمـام من قبل القائمين على إنشاء تلك المشروعات بإعداد دراسـات جدوى للمشروعات الاقتصادية قبل الشروع في تنفيذها: الأمر الأي يجعلها في موقف تمويلي أو تسويقي أو إنتاجي ضعيف وغير ملائسم لمتطلبـات السوق أو

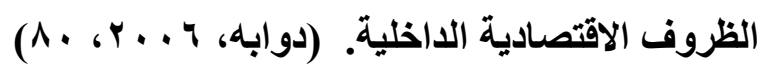

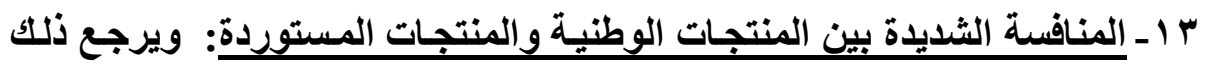
إلى الحرية شبه المطلقة للاستيراد من السوق الخـارجى، وأحيانـا بالأسـاليب

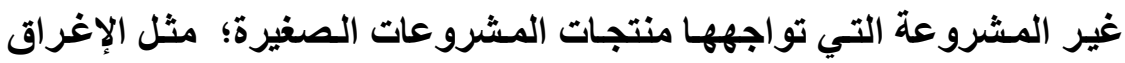
والتهرب من الضرائب وتهريب المنتجات الفاسدة أو غير المطابقة للمواصفات

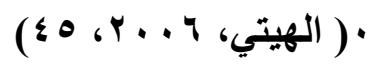

ع ا-زيادة مخاطر الاستثمار: بسبب محدودية تحمل الخسائر في ظل تعثر الأوضساع السياسية والاقتصادية وضعف القدرة على التتبؤ بالمستقبل، وتواضع حجم

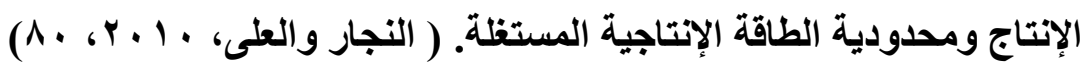
ه 1 ت تفضيل المستهلك المصرى للمنتجـات الأجنبيـة أحيانـا: وقد يكون ذلك راجعا لعوامل نفسية مرتبطة بقتاعته لفترة زمنية طويلة بالسلع المستوردة (عقدة (الخواجة).

17 ـ الوضسع غير الرسمى للمشروعات الصغيرة: يسود الوضـع غير الرسمي في

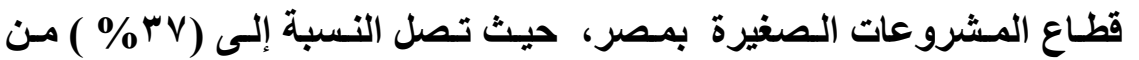
إجمالي الناتج المحلي؛ وتثير بيانات مسح سوق العمل المصري إلى أن أكثر من (• \% \% ) من العمال العاملين بأجر في القطاع الخـاص يعملون بشكل غير

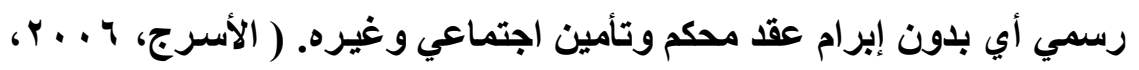

V ا - ارتفـاع نسب الحـوادث والإصـابات أثنـاء العملي: نتيجـة الجهل بقواعد الأمـن الصناعي ومستلزمات السلامة المهنية لاى العاملين وأرباب العمل، فضلاً عن العن 
العوامل النفسية والإجهاد الذي يصيب العامل إضافة إلى ظروف العمل القاسية.

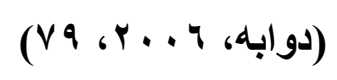

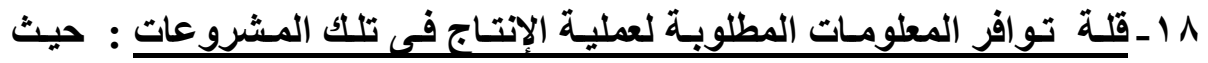

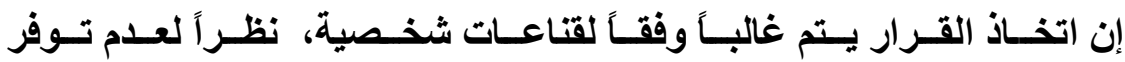
المطومات الصحيحة والدقيقة عن المشكلة التي يتخذ حيالها القرار، علاوة

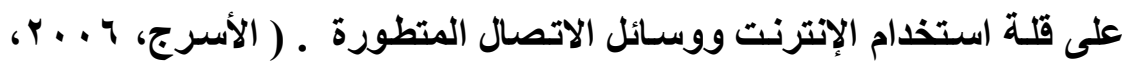

وبعد تشخيص أهم الصعوبات والتحديات التى تواجـه أصحاب المشروعات

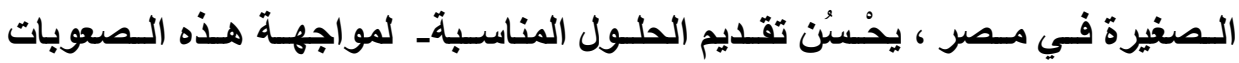

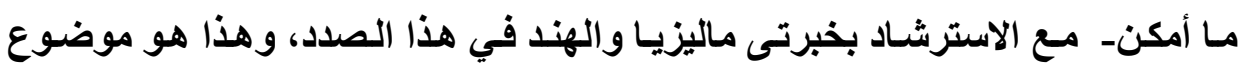

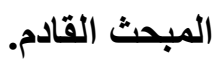




\section{المبحث الخاهس \\ سبل النهوض بالمشروعات الصغيرة}

في إطار السعي لتذليل الصعوبات التي تواجها المشروعات الصغيرة في مصر

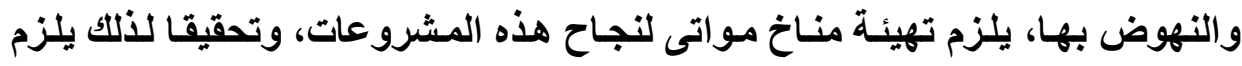

ا - توفير إطار قانوني وتشريعي منظم لعمل المشروعات الصغيرة ، والمتمثل في

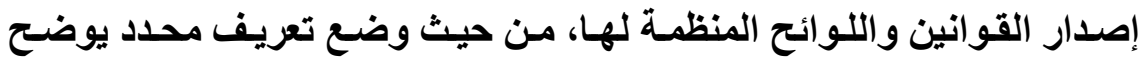

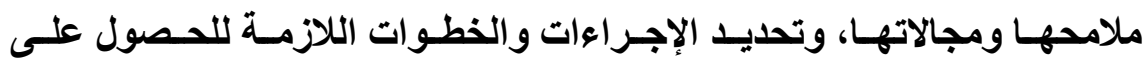

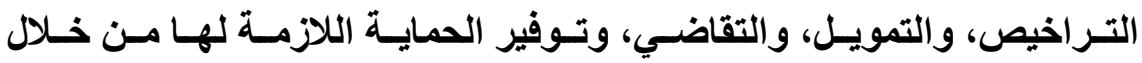
إجراءات قانونية خاصة. r- إنشاء هيئات ومؤسسات حكومية أو غير حكومية، مهمتهـا الأساسية هي دعم المشروعات الصغيرة وتنميتها، وتذليل الصعوبات التي تواجها تلكك المشروعات التهيل

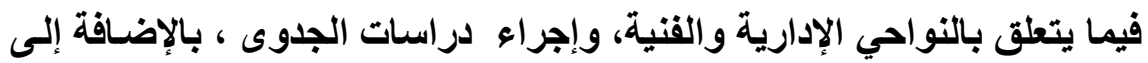
إقامة مناطق وتجمعات صناعية. r- إنشاء مؤسسات ماليـة متخصصة في تمويل المشروعات الصغيرة وبأسعار فائدة منخفضة وشروط ميسرة، والمساهمة في حل المشكلات والأزمـات المالية التي قد تتعرض لها تلك المشروعات. ع - إنشاء صناديق ضمان مخاطر الائتمـان الممنوح للمشروعات الصغيرة ؛ بهدف

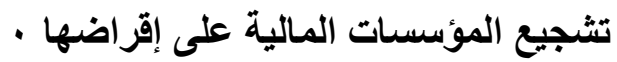
هـ إنشاء جهـات تتـولى مسساعدة المشروعات الصغيرة على تسويق وتصدير منتجاتهـا، وتخـصيص جزء مـن العقـود والمـشتريات الحكوميـة للمشرورعات

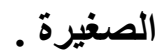




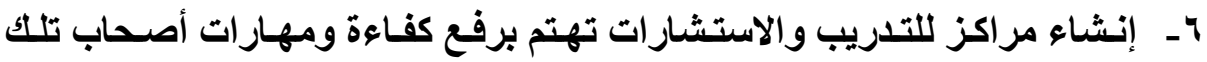

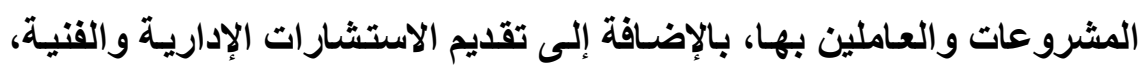
وتوفير المعلومات والبيانات.

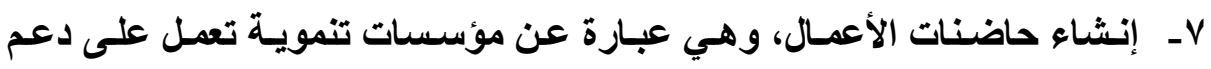

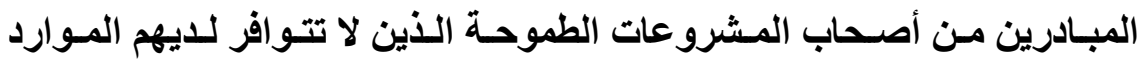

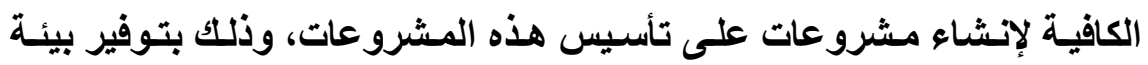

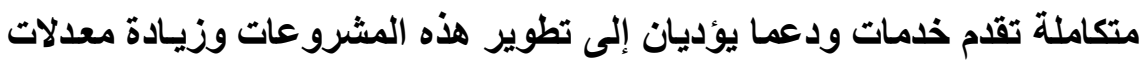
نموها وكفاعتها الاقتصادية.

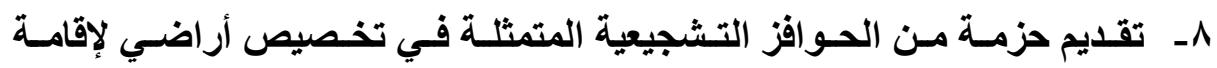

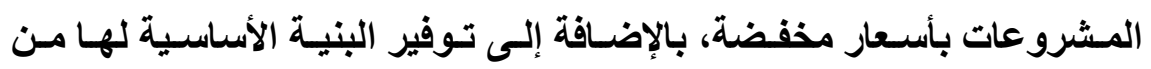

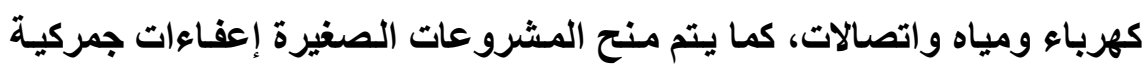

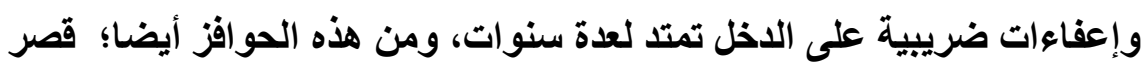

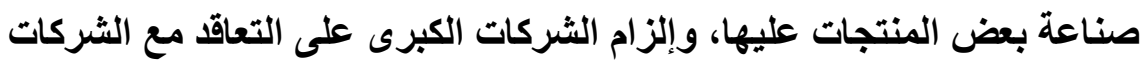
الصغيرة لتوفير أجزاء

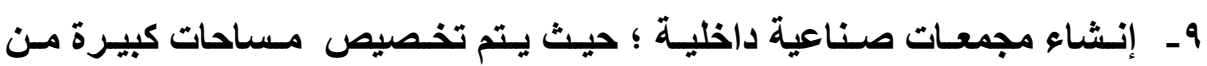

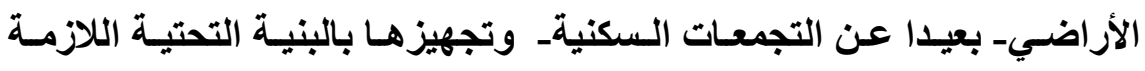
الإقامة صناعات متعددة ومختلفة الأحجام والتخصصات.

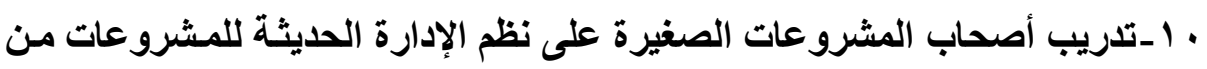

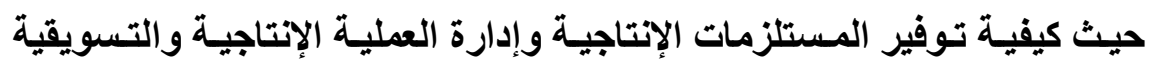
وكيفيـة التعامـل مـع البنـوك والمؤسسـات الحكوميـة، وتـوفير التـدريب المهنـي

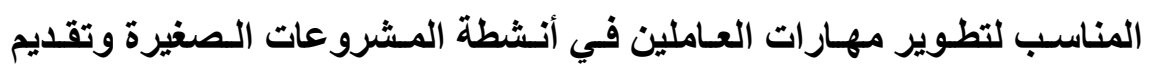

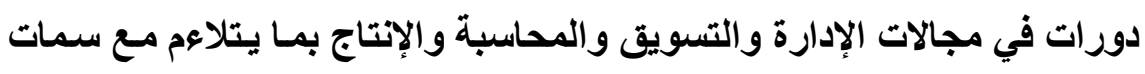
وخصوصيات هذه المشروعات. 1 اـتظيم المعارض المتخصصة لترويج وتسويق منتجات المشروعات الصغيرة ونشر المعلومات التسويقية اللازمة لمساعدتهم على تسويث منتجاتهم ـ 
r ا ـ تفعيـل دور الجمعيـات والاتحسادات التضامنية للمششروعات المتجانسسة مثل مئل

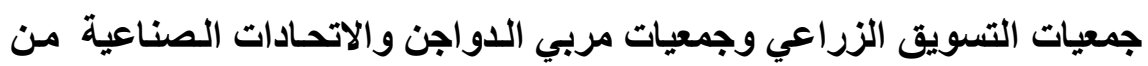

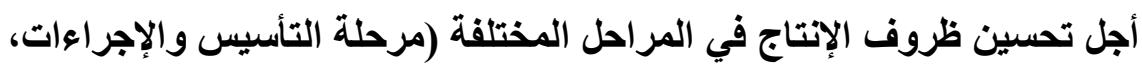

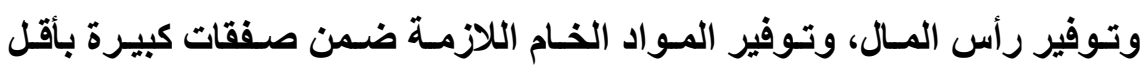
التكاليف، والإتتاج والتسويق).

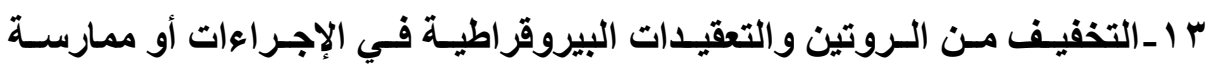
الأنثطة الاقتصادية من قبل المسئولين والجهات الرقابية.

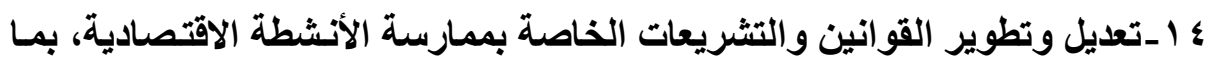

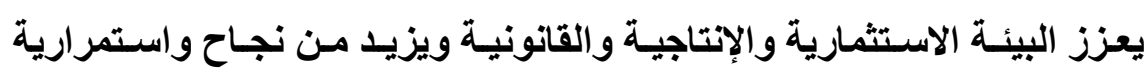

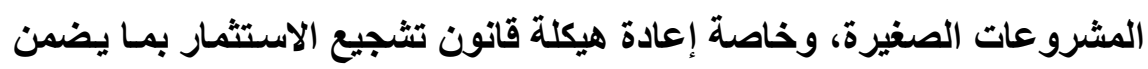

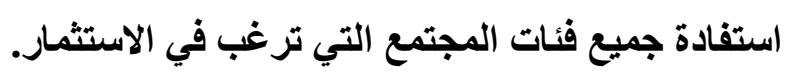

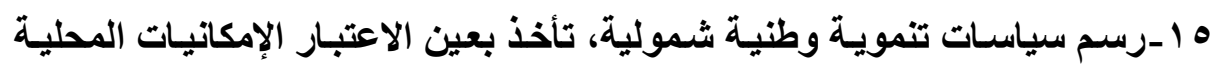

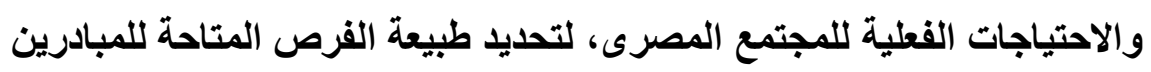
وأصحاب المشروعات الصغيرة في القطاعات المختلفة.

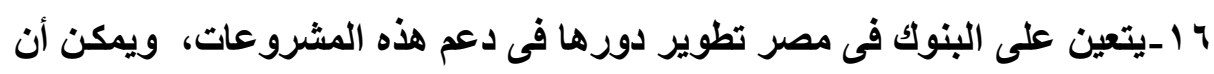

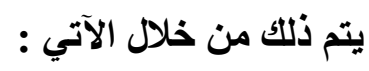
- تخصيص وحدة بكل بنكل تكون مغنيـة بالتعامل مـع أصـاب المشروعات

$$
\text { الصغيرة. }
$$

- تدريب الموظفين العاملين بتلك الوحدة وتعزيز مهار اتهم الإدارية ووعيهم بطبيعة تلك المشروعات واحتياجاتها.

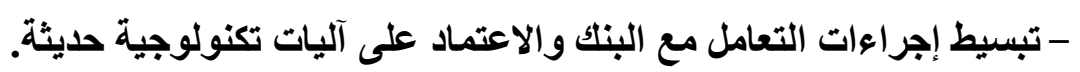

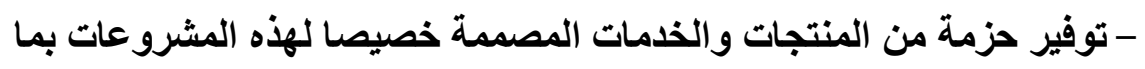
يتلاءم مع احتياجات كل قطاع على حدة.

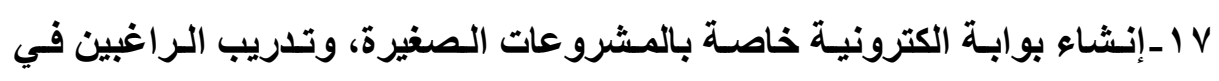
إقامة المشرو عات الصغيرة و العاملين بها على التعامل معها. 
1 1 ـتنظيم زيـارات ميدانيـة إلى الـدول المتقدمـة فـى مجـال المشروعات الـصغيرة

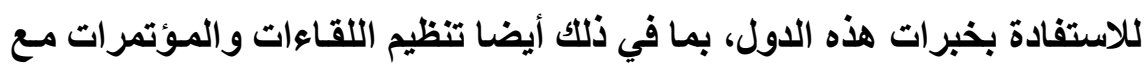
جهات محلية ودولية متخصصة في هذا المجال.

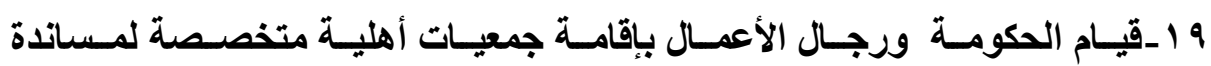

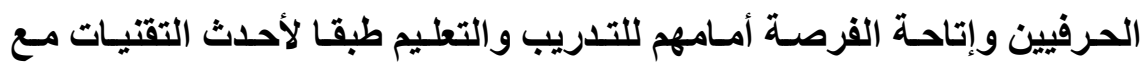

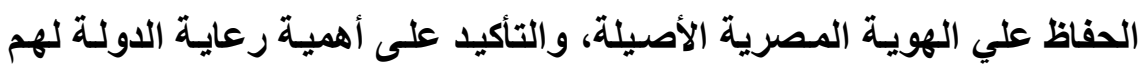

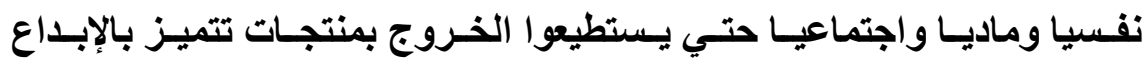
والأصالة. • • ـ استخدام المعلومات والبحوث ركيزة أساسية لاتخاذ القرارات الإداريـة والاهتمـام

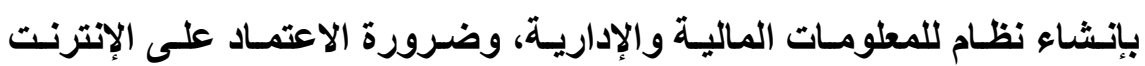
ووسائل الاتصالات الحديثة.

ا Y_الابتعاد قرر الإمكان عن مصادر التمويل غير الرسمي وذلك لمـا تتضمنه هذه المصادر من إجحاف بأصحاب هذه المشروعات. r ץ ـضرورة حجز بعض الفقرات الإتتاجية لصالح الصناعات الصغيرة وعدم السماح

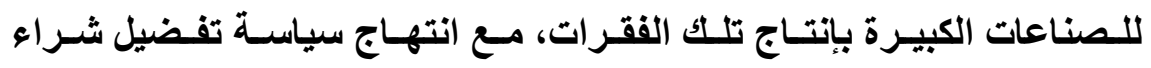
المنتجات من الصناعات الصغيرة للمؤسسات الحكومية.

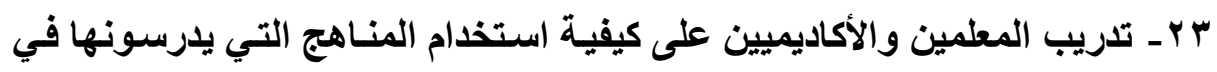
توليد الأفكار للمشروعات الصغيرة وإدارتها. 


\section{الخاتهة والتوصيات}

تمحورث فكرة هذا البحث حول الأهميـة الاقتصادية للمشروعات الصغيرة باعتبارها من أنسب البدائل لتحقيق التنمية الاقتصادية والاجتماعية ، وجاء الاهية البحث في في خمسة محاور:

الأول؛؛ تناول ماهية المشروعات الصغيرة وأهم السمات التي تتميز بها وتضفي

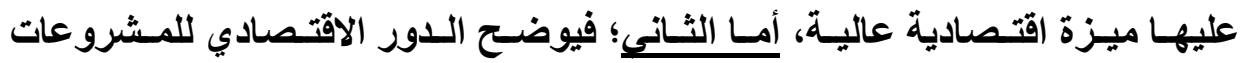

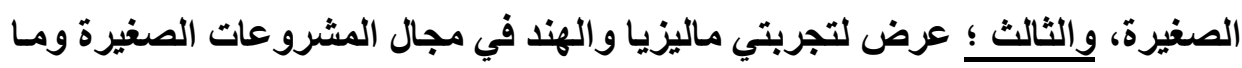

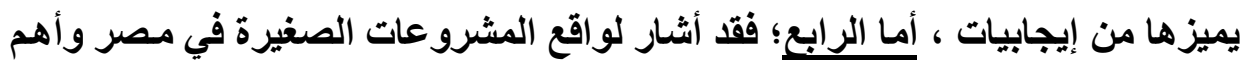

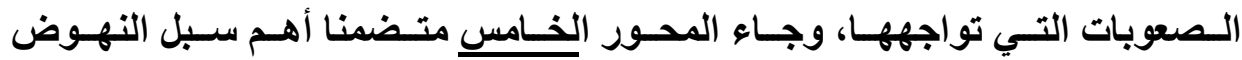

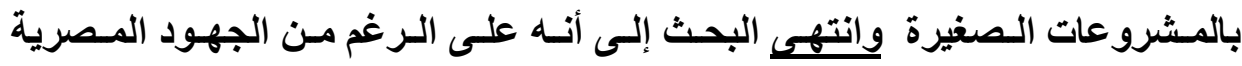

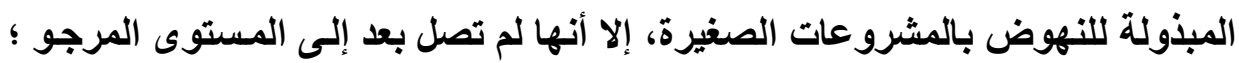
وفي هذا السياق يوصي البحث بالآتي:

ا ـضرورة الاهتمام بالتعليم الريادي - في مختلف المراحل الجامعية وقبل الجامعيةــ

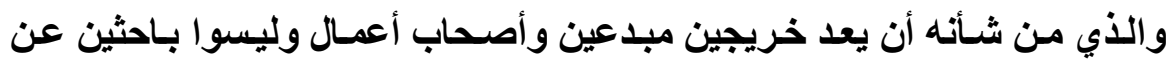
وظائف تقليدية. r ـنشر ثقافة العمل الحر ، وتدريب الشباب وإكسابهم المهارات التي تمكنهم من

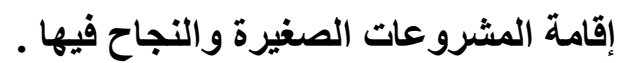

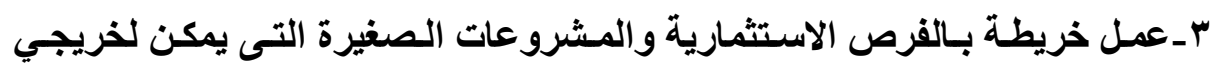

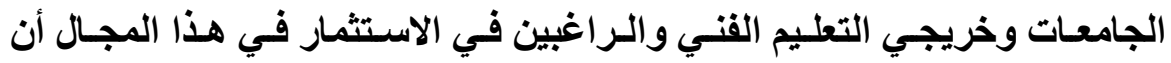

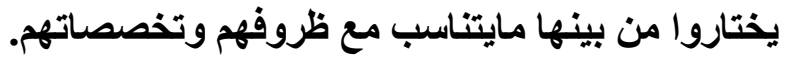

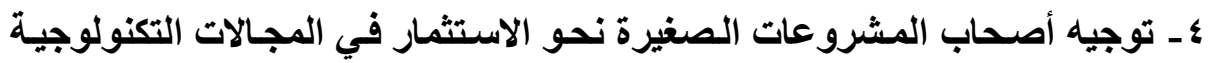

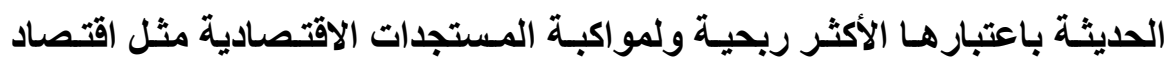
المعرفة.

وختاما يؤكد البحث على أن الاستثمار في المشروعات الصغيرة والتوسـع فيها

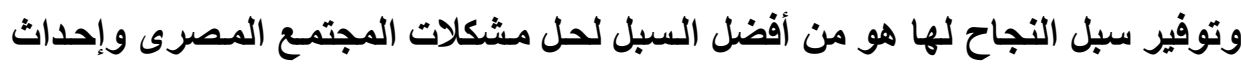

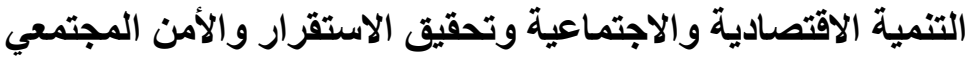




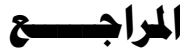

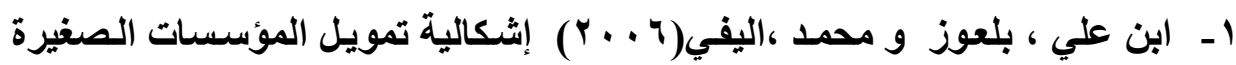

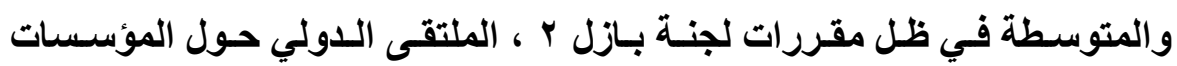

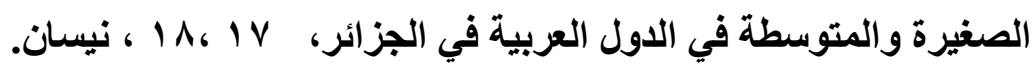

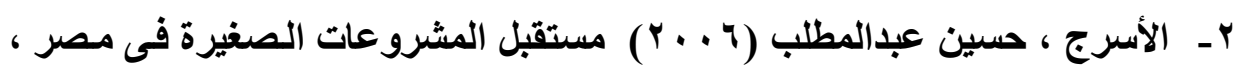

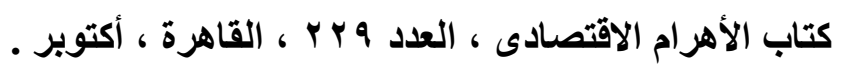

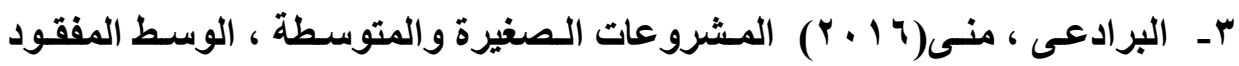

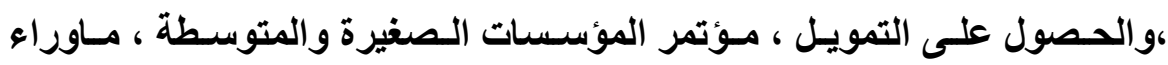

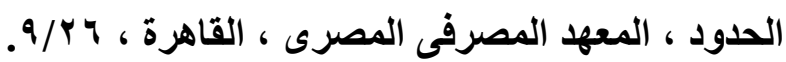

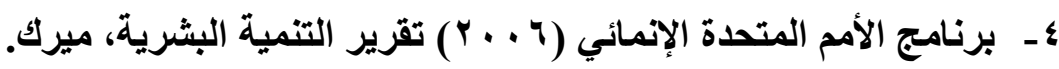

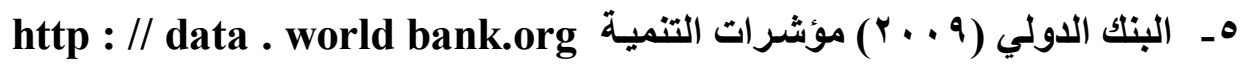

\section{/ indicator / Ic.ERM.BNKS.ZS}

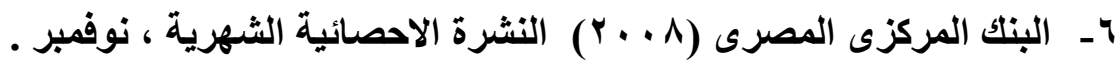

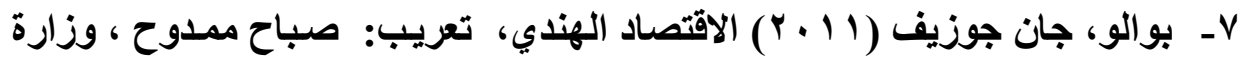

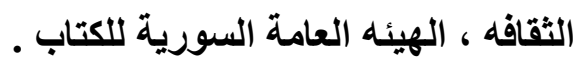

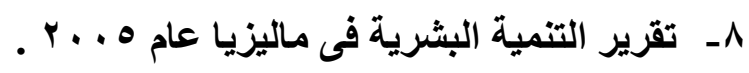

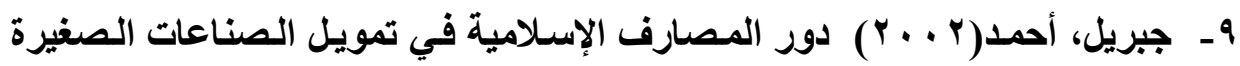
بالتطبيق على بنك فيصل الإسـلامي السوداني، مؤتمر دور المؤسسات المصرفية

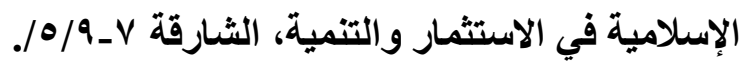

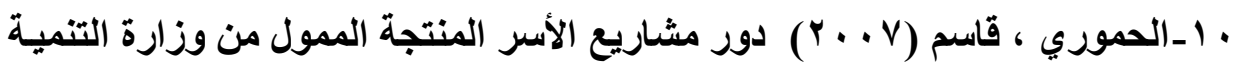

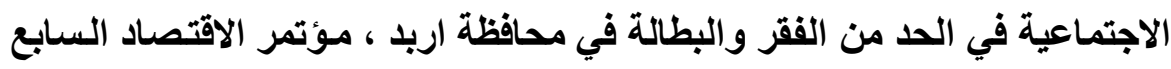

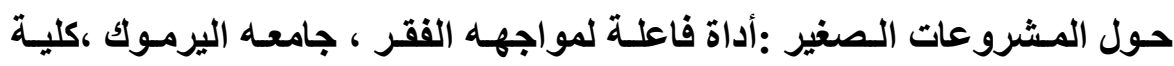

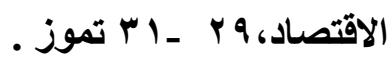




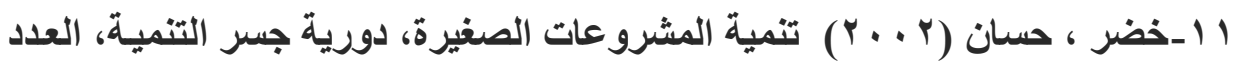

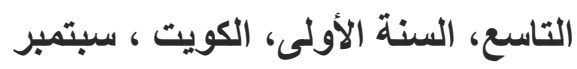

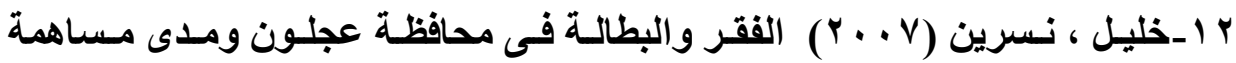

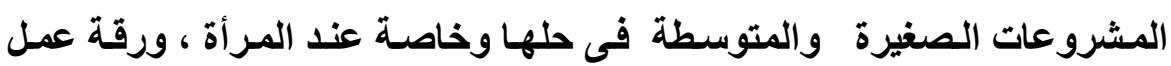

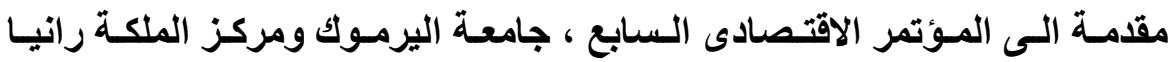

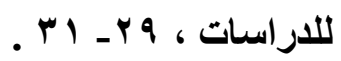

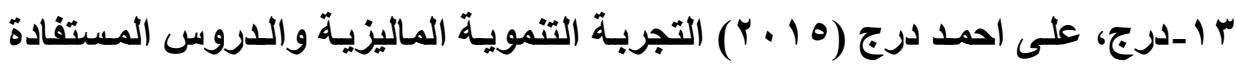

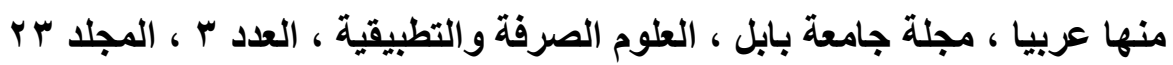

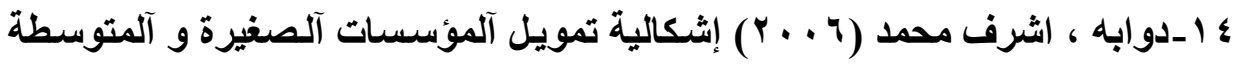

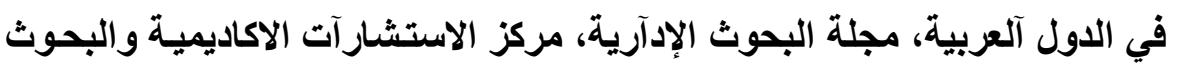

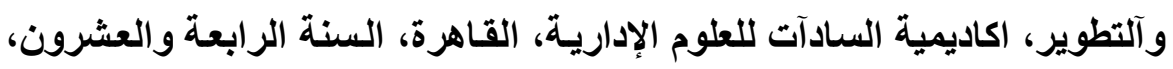

$$
\text { العدد الرابع }
$$

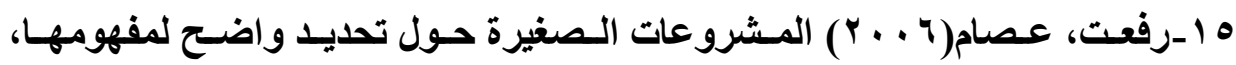

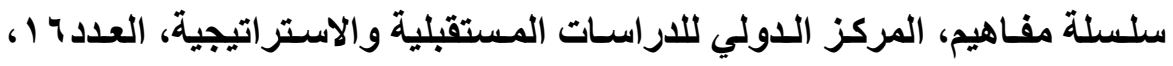
ابريل.

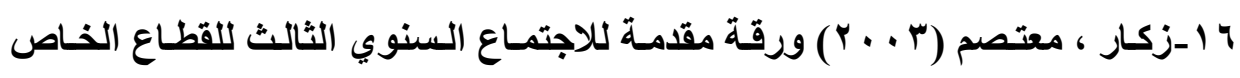

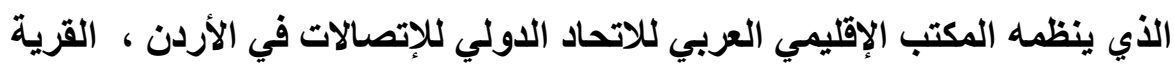

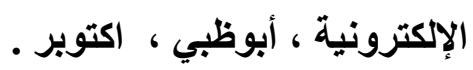

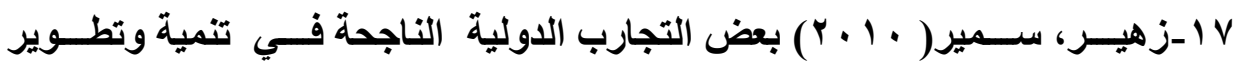
المشروعات الصغيرة والمتوسطة ، ، مكتب محافظة قلقلية فلسطين.

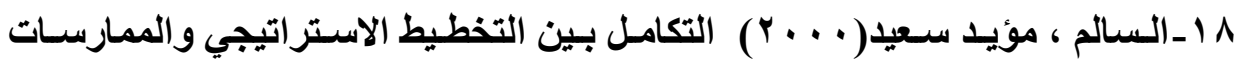

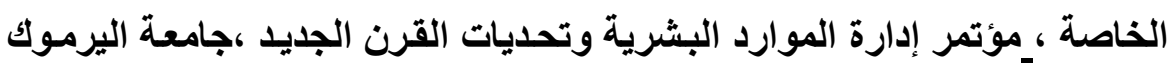

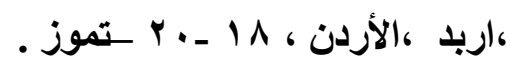


9 ا ـالسعدى ، أحمد (؟ . . ץ) دور ومكانة الصناعات الصغيرة في التنمية الاقتصادية

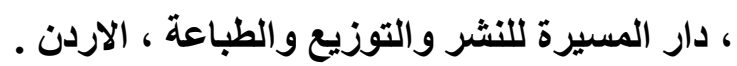

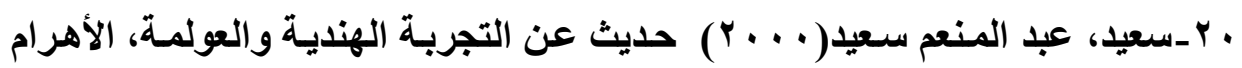

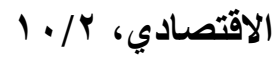

ا ـ سليمان، ربيعة (1 9 9 1) الصناعات الصغيرة ودورها فى عملية التنمية فى سوريا

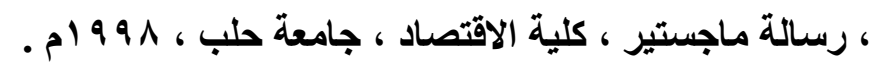

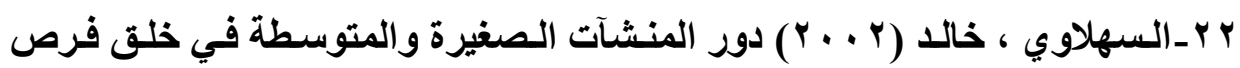

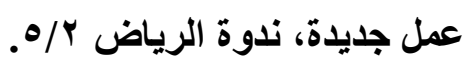

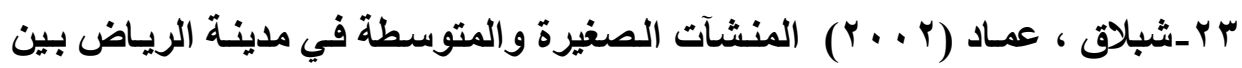

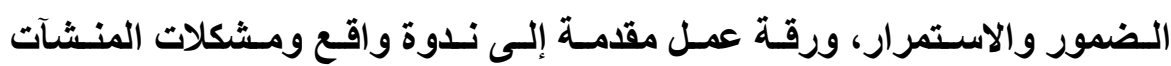

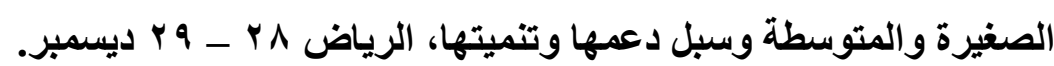

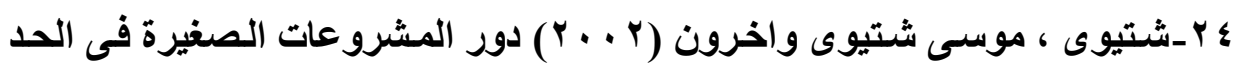

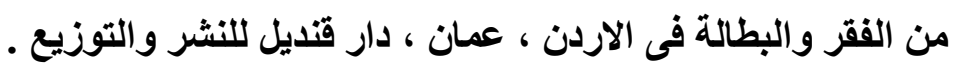

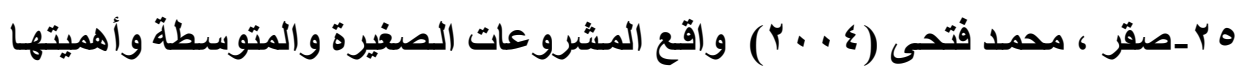

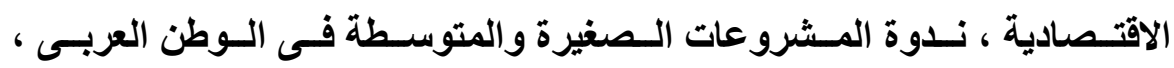

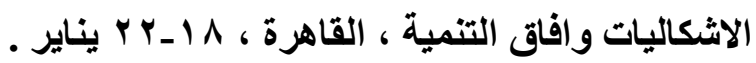

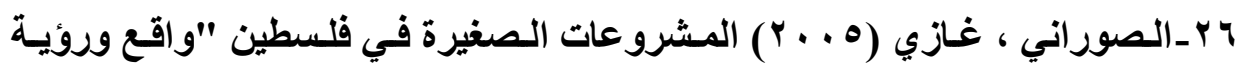
نقدية"، يونيو.

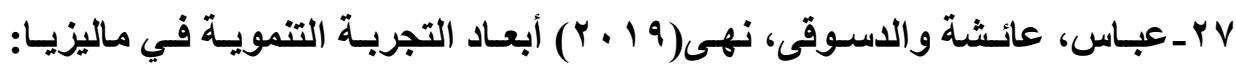

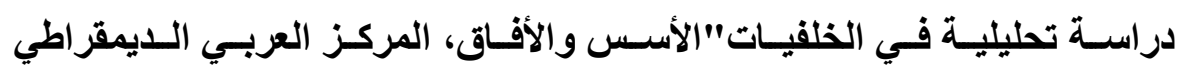
للاراسات الاستراتيجية والسياسية والاقتصادية، برلين ، ألمانيا

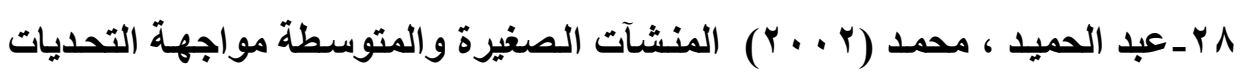

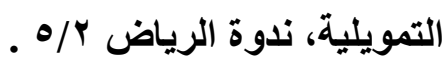




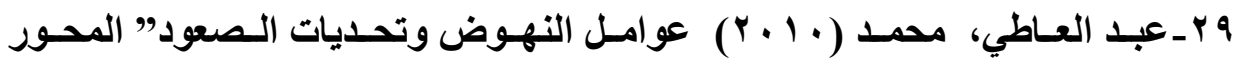

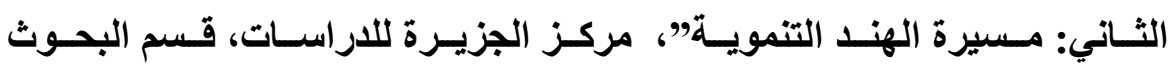

$$
\text { والاراسات }
$$

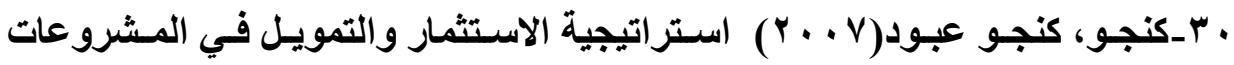
الصغيرة دراسـة ميدانيـة للمشروعات الصغيرة في ملينـة حلب، المؤتمر العلمي

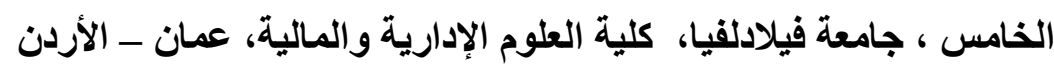

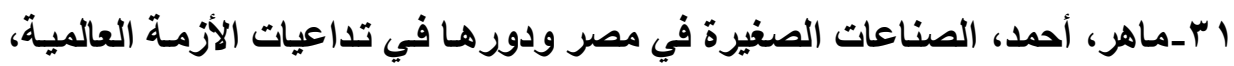
مقال على الانترنت على الرابط التالي: ملهئ

http://digital.ahram.org.eg/articles.aspx?Serial=97585\&eid=52

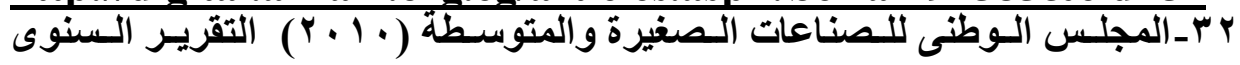
$r \cdot 1 \cdot / r . . q$

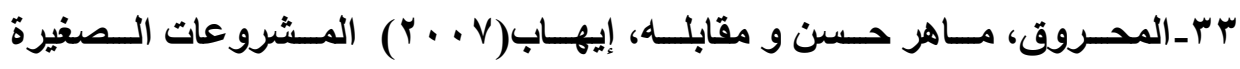

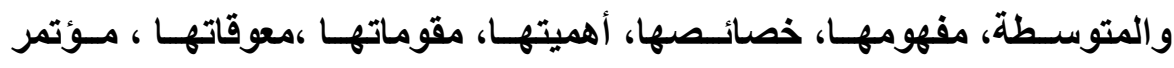
الاقتصاد السابع حول المشروعات الصغير :أداة فاعلـة لمواجهه الفقر ، جامعـه

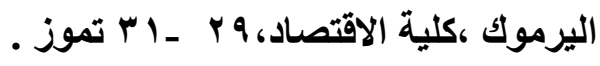

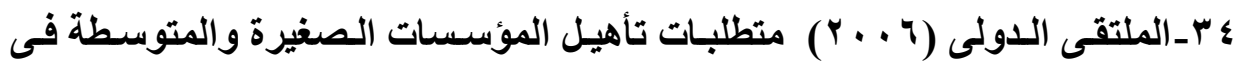

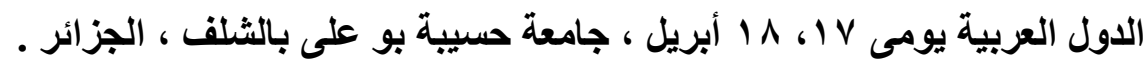

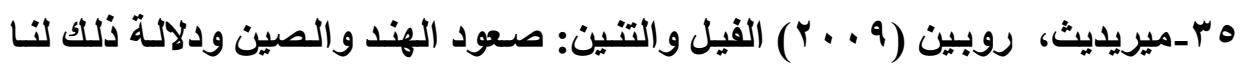

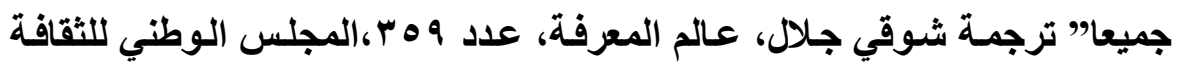

$$
\text { والفنون والآداب، الكويت ، يناير. }
$$

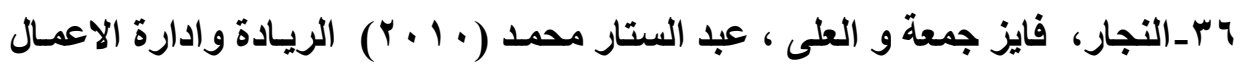
الصغيرة ، عمان ، دار الحامد للنشر والتوزيع ، الطبعة الثانية.

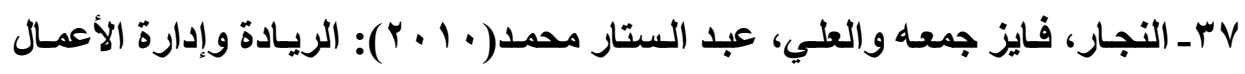

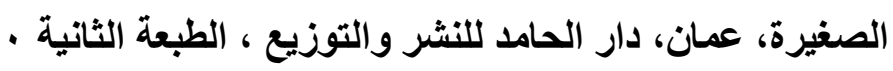


^ץ ـالنسور،إياد عبد الفتاح علي (999 99 1) دور المؤسسات التمويلية الحكومية في تنميـة المسشروعات الصغيرة في الأردن ،رسـالة ماجستير غيـر منشورة ،قسم الاقتصاد الجامعة الأردنية ،عمان

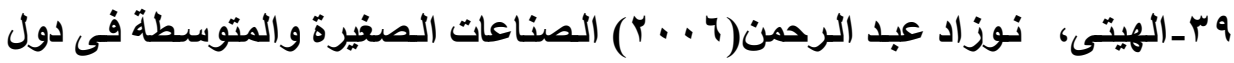
مجلس التعـاون الخليجى ، الوضـع القـائم والتحـديات المستقبلية ، مجلـة المـال

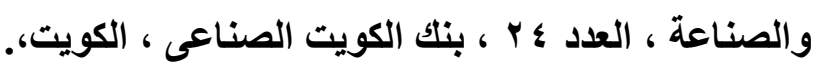

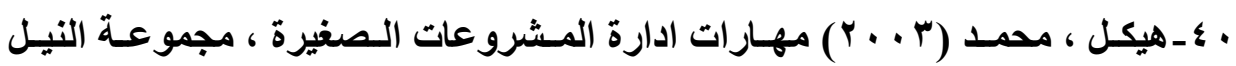

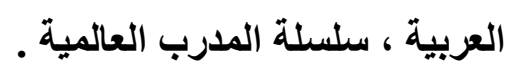

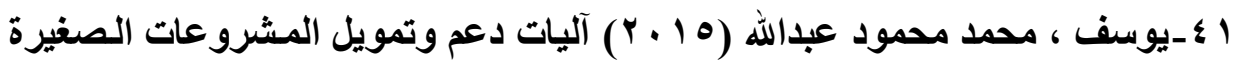

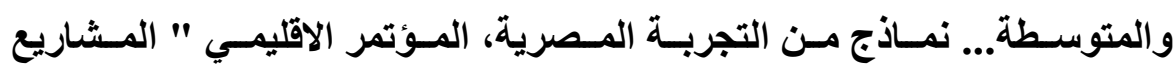

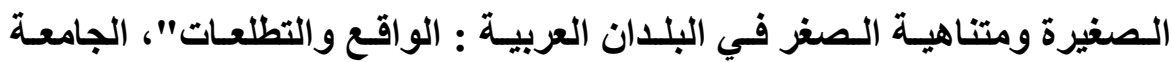

$$
\text { العربية المفتوحة، الكويت، أكتوبر . }
$$

42-Aygagari, Moghnana and other (2003) small and Medium Enterprises Across the globe-Research paper 3127, world Bank, august

43- Bipan, Chandr(2001) India after Independence 1947-2000, Penguin Books

44- business.mapsofindia.com

45- Cheng ML\& Chan WS \& Amir M (2009). The effectiveness of entrepreneurship education in Malaysia. Journal Education and Training; 51(7):555-566.

46- https://small-

projects.org/\%D8\%A7\%D9\%84\%D8\%A7\%D8\%B3\%D8 \%AA\%D8\%AB\%D9\%85\%D8\%A7\%D8\%B1- 
د./ حازم السيد حلمى عطوة

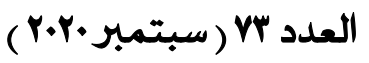

\%D9\%81\%D9\%8A-

\%D9\%85\%D8\%A7\%D9\%84\%D9\%8A\%D8\%B2\%D9\%8

A\%D8\%A7/

47- Moh, Ghazali Younes (2006) Technology capacity Building for SMES. Sharing of Malaysian Experience .

48- National SME Development council(2010) SME Annual Report 2009/10 .

49-said , Hala(2016), exploring the importance and the current status of Egypt SMEs, may .

50-Sawe, Benjamin Elisha(2017). "The Economy Of Malaysia." WorldAtlas, Apr. 25, worldatlas.com/articles/the-economy-of-malaysia.html., Retrieved 10-5-2018. Edited

51- The Indian government report 2015

52- Thorsten, Beek and Aygagari Meghana (2003) Small and medium nterprises across the globe : a new database, world bank policy research, Vol.1

53-W.B. ISO certification ownership bttp:/data.worldbank.org/indieator/Ic.FRM.ISOC.ZS

54- web.worldbank.org

55- Wilson, Brain(1986)The Small Business Hand Book ,Basill black well inc, New York .USA.

56-World Bank , Ease of doing business Index, http://data.worldbank.org/indicator/ic.bus.ease.xq 